EL ABUSO SEXUAL CONTRA NIÑOS, NIÑAS Y ADOLESCENTES EN BOYACÁ. SITUACIÓN DE LAS VÍCTIMAS FRENTE A LAS POLÍTICAS PÚBLICAS Y EL PROCESO JUDICIAL

YOLIMA TRIANA ROBLES

UNIVERSIDAD SANTO TOMÁS

MAESTRÍA EN DERECHOS HUMANOS

BOGOTÁ, D. C.

2019 
EL ABUSO SEXUAL CONTRA NIÑOS, NIÑAS Y ADOLESCENTES EN BOYACÁ. SITUACIÓN DE LAS VÍCTIMAS FRENTE A LAS POLÍTICAS PÚBLICAS Y EL PROCESO JUDICIAL

YOLIMA TRIANA ROBLES

Maestría en Defensa Internacional de los Derechos Humanos

Director

HELBER ARMANDO NOGUERA SANCHEZ

UNIVERSIDAD SANTO TOMÁS

MAESTRÍA EN DERECHOS HUMANOS

BOGOTÁ, D. C.

2019 
Atodos aquellos pequeños inocentes que vieron su infancia truncada Para que su voz pueda escucharse y no sea el silencio de la impunidad Loque más duela. 


\section{CONTENIDO}

Pág.

INTRODUCCIÓN

CAPÍTULO 1

1.1. MARCO TEÓRICO 14

1.1.1. El abuso sexual contra los NNA. Generalidades 14

1.1.2. Políticas públicas colombianas contra la violencia sexual 18

1.1.2.1. Documento Conpes Social 109, de diciembre de 2007

1.1.2.2. Plan Nacional para la Niñez y la Adolescencia 2009-2019 23

1.1.2.3. De Cero a Siempre $\quad 25$

1.1.3. El proceso judicial, en los casos del ASI en los NNA 27

CAPÍTULO 2

2.1. ESTÁNDARES INTERNACIONALES Y NACIONALES EN MATERIA DE PROTECCIÓN JURÍDICA A LA POBLACIÓN VÍCTIMA DE VIOLENCIA SEXUAL 31

2.1.1. Estándares internacionales $\quad 31$

2.1.1.1. Sistema universal de protección de derechos humanos dentro del marco de las

Naciones Unidas $\quad 32$

2.1.1.1.1. Convención sobre los Derechos del Niño (CDN) 32

2.1.1.1.2. Protocolo Facultativo de la Convención sobre los Derechos del Niño relativo a la venta de niños, la prostitución infantil y la utilización de niños en la pornografía 35

2.1.1.1.3. Convención para la Eliminación de todas las Formas de Discriminación contra la Mujer (CDAW)

2.1.1.1.4. Convenio 182 sobre las peores formas de trabajo infantil (Ley 704 de 2001) 37

2.1.1.1.5. Protocolo para prevenir, reprimir y sancionar la trata de personas, especialmente de mujeres y niños $\quad 37$

2.1.1.2. Sistema Interamericano de Protección de los Derechos Humanos y especialmente de los derechos de los NNA

2.1.1.2.1. Declaración Americana de los Derechos y Deberes del Hombre 40

2.1.1.2.2. Convención Interamericana sobre Desaparición Forzada de Personas, Belem Do 
Pará, Brasil, 9 de junio de 1994.

2.1.1.2.3. Protocolo Adicional a la Convención Americana sobre Derechos Humanos en Materia de Derechos Económicos, Sociales y Culturales "Protocolo de San Salvador" 41

2.1.1.2.4. Carta Democrática Interamericana

2.1.1.2.5. Convención Americana - Pacto de San José. San José, Costa Rica, 22 de noviembre de 1969

2.1.1.2.6. Convención interamericana para prevenir, sancionar y erradicar la violencia contra la mujer “Convención de Belem Do Para”. Belem Do Pará, Brasil, 1994

2.1.1.3. Esfuerzos jurisprudenciales

2.1.1.3.1. Respecto a la definición de niño 46

2.1.1.3.2. Las “medidas de protección” a favor de los NNA 46

2.1.1.3.3. Los derechos de los NNA como un "derecho adicional” 47

2.1.1.3.4. El interés superior del niño $\quad 47$

2.1.1.3.5. Conclusión estándares Sistema Interamericano 47

2.1.2. Estándares nacionales $\quad 48$

2.1.2.1. Constitución Política (1991) 48

2.1.2.2. Ley orgánica de la defensa del niño 49

2.1.2.3. Ley 75 de $1968 \quad 49$

2.1.2.4. Ley 7 de $1979 \quad 50$

2.1.2.5. Código del Menor $\quad 51$

2.1.2.6. Ley 679 de $2001 \quad 52$

2.1.2.7. Ley 1098 de 2006

2.1.2.8. Ley 1146 de $2007 \quad 55$

2.1.2.9. Decreto 936 de 2013

2.1.2.10. Decreto 87 de $2017 \quad 56$

2.1.3. Jurisprudencia de las diferentes Cortes colombianas para la protección de los derechos de los NNA

2.1.3.1. Abuso sexual contra los NNA

2.1.3.2. Capacidad para el ejercicio de la sexualidad referida a los NNA 60

2.1.3.3. Valor del testimonio de los NNA frente a los procesos de violencia sexual 62 
2.1.3.5. El derecho de los niños a no ser objeto de violencia sexual 64

2.1.3.6. La prevención y protección contra el abuso sexual $\quad 64$

$\begin{array}{ll}\text { 2.1.3.7. El interés superior del niño } & 65\end{array}$

2.1.3.8. Conclusiones 66

CAPÍTULO $3 \quad 65$

3.0. ABUSO SEXUAL EN BOYACÁ

3.1. Descripción metodológica $\quad 65$

3.2. Recolección de información $\quad 71$

3.3. Sentencias objeto de análisis 66

$\begin{array}{ll}\text { 3.4. Ficha para análisis de sentencias } & 70\end{array}$

3.5. Aspectos para determinar la situación de las víctimas en el juicio 72

3.5.1. Aplicación instrumentos 73

3.5.1.1. Aplicación de los instrumentos de protección y atención para las víctimas $\begin{array}{ll}\text { de ASI establecidos por las Políticas Públicas } & 73\end{array}$

3.5.1.2. Seguimiento de los protocolos para la realización de los diferentes procedimientos $\quad 76$

3.5.1.3. Conocimiento de los operadores judiciales de los estándares internacionales en protección de las víctimas de ASI.

3.5.1.4. Debida diligencia por parte de los operadores judiciales al momento de investigar y realizar el proceso judicial

3.5.1.5. Conocimiento de los jueces y magistrados de la normatividad nacional e internacional y la jurisprudencia al momento de valorar los testimonios de las víctimas. 83

3.5.1.6. Articulación de las entidades encargadas de la protección de los NNA. 85

3.5.1.7. Aplicación de la normatividad colombiana y la jurisprudencia en el desarrollo del proceso judicial teniendo en cuenta el interés superior de los NNA. 86

$\begin{array}{ll}\text { 3.5.2. Casos Puntuales } & 87\end{array}$

$\begin{array}{lr}\text { 3.5.2.1. Caso Tatiana } & 87\end{array}$

$\begin{array}{ll}\text { 3.5.2.2. Caso de Yury N } & 90\end{array}$

$\begin{array}{ll}\text { 3.5.2.3. Caso Adolescentes } & 91\end{array}$

CAPÍTULO $4 \quad 82$

4.1. CONCLUSIONES 93 
4.1.1. Adopción de la normatividad 94

4.1.2. Dificultad de la denuncia de situaciones en los hogares 94

4.1.3. No se implementa la protección superior del niño 95

4.1.4. Existe violencia sexual infantil 95

4.1.5. El Estado colombiano refuerza su lucha contra esta problemática 97

4.1.6. Se presenta desarticulación de las entidades públicas involucradas 97

4.1.7. No se reducen los casos, solo se aumentan las penas 97

4.1.8. Se tienen fallas en la prevención y protección contra el abuso y la violencia $\begin{array}{ll}\text { sexual infantil } & 99\end{array}$

4.1.9. Faltan redes de apoyo para los jueces y magistrados 99

4.1.10. El abuso sexual contra los NNA no para 99

4.1.11. En Colombia se lucha contra el ASI a través de la normatividad y la jurisprudencia 100

4.1.12. Falta de aplicación del interés superior del niño 100

4.1.13. El aumento de las penas no disuade al agresor 101

4.1.14. Existe incumplimiento de los estándares de protección al menor 101

4.1.15. Se presenta preponderancia del proceso judicial sobre los derechos de la víctima 101

4.1.16. Colombia ha avanzado en la protección de los derechos de los NNA 102

4.2. RECOMENDACIONES 103

4.2.1. En cuanto a la falta educación y prevención 103

4.2.2. Respecto a los fracasos de las políticas públicas 103

$\begin{array}{ll}\text { REFERENCIAS } & 105\end{array}$

\section{LISTA DE TABLAS}

Tabla 1. Número de exámenes médicos por presunto abuso sexual 2005-2011 10

Tabla 2. Exámenes médico-legales por presunta violencia sexual en Boyacá 11

Tabla 3. Exámenes médico-legales por presunto abuso sexual por edad 2015

Tabla 4. Normas colombianas vigentes para la protección de NNA 55

Tabla 5. Sentencias objeto de análisis $\quad 66$

$\begin{array}{ll}\text { Tabla6. Ficha para análisis } & 70\end{array}$ 


\section{CONVENCIONES}

ASI: Abuso Sexual Infantil.

CADH: Convención Americana de Derechos Humanos.

CAIVAS: Centro de Atención Integral a Víctimas de Abuso Sexual.

CAPIV: Centro de Atención Penal Integral a Víctimas.

CAVIF: Centro de Atención e Investigación Integral Contra la Violencia Familiar.

CDN: Convención sobre los Derechos del Niño.

CDAW: Convención para la Eliminación de todas las Formas de Discriminación contra la Mujer (por su sigla en inglés).

CIDH: Comisión Interamericana de Derechos Humanos.

CRNV: Centro de Referencia Nacional sobre Violencia.

CTI: Cuerpo Técnico de Investigación.

ICBF: Instituto Colombiano de Bienestar Familiar.

IE: Institución Educativa.

INMLCF: Instituto Nacional de Medicina Legal y Ciencias Forenses.

NNA: Niños, niñas y adolescentes.

OEA: Organización de Estados Americanos.

OIT: Organización Internacional del Trabajo.

OMS: Organización Mundial de la Salud.

ONU: Organización de las Naciones Unidas.

SIM: Sistema de Información Misional.

SIVELCE: Sistema de Vigilancia Epidemiológica de Lesiones de Causa Externa.

SNBF: Sistema Nacional de Bienestar Familiar.

UNICEF: Fondo de las Naciones Unidas para la Infancia. 


\title{
EL ABUSO SEXUAL CONTRA NIÑOS, NIÑAS Y ADOLESCENTES EN BOYACÁ. SITUACIÓN DE LAS VÍCTIMAS FRENTE A LAS POLÍTICAS PÚBLICAS Y EL PROCESO JUDICIAL
}

\author{
Yolima Triana Robles \\ UNIVERSIDAD SANTO TOMÁS
}

\section{RESUMEN}

La presente tesis se propone abordar el abuso sexual de los niños en Boyacá, partiendo del análisis de los mecanismos que se han implementado para tratar de evitarlo, en el ámbito internacional y nacional.

En el proyecto, se estudian los estándares internacionales de los cuales Colombia hace parte, especialmente la Convención sobre los Derechos del Niño y los estándares nacionales aplicables a la problemática; así mismo, se presenta un breve análisis de la situación en el departamento de Boyacá.

PALABRAS CLAVES: Víctimas, abuso sexual, menores, defensa judicial de víctimas, derechos humanos, estándares internacionales, derecho a la justicia, la verdad y la protección.

\section{ABSTRACT}

The present thesis aims to address the sexual abuse of children in Boyacá, starting from the analysis of the mechanisms that try to avoid it, both internationally and nationally.

The international standards of Colombia are studied, in particular the Convention on the Rights of the Child and national standards, applicable to the issue; also, a brief analysis of the situation in the department of Boyacá is presented.

KEY WORDS: Victims, Sexual Abuse, Minors, Victim Advocacy, Human Rights, International Standards, Right to Justice, Truth and Protection. 


\section{INTRODUCCIÓN}

El abuso sexual en menores se ha venido trabajando intensamente a nivel mundial, por ser una problemática que está afectando de manera alarmante a todos los países y en todas las escalas de la sociedad.

Desde diferentes orillas se ha tratado de visibilizar el problema que durante mucho tiempo estuvo bajo un manto de impunidad y de silencio; tanto los gobiernos como las entidades no gubernamentales y actores privados han venido sacando a la luz pública, una realidad aberrante de esta forma de maltrato a la niñez que tiene un efecto devastador en nuestros niños.

La UNICEF, por ejemplo, ha iniciado campañas con el fin de dar la protección a los niños. Así, como parte de estos programas da a conocer informes da a conocer las cifras de abusos a menores, tanto a niñas como a niños, y realiza en unión con los gobiernos del mundo y especialmente con Latinoamérica, foros que permitan encontrar una voz para la protección de esta forma de abuso.

Internacionalmente es muy conocido el trabajo que ha venido desarrollando la organización no gubernamental (ONG) con sede en Ginebra, Suiza, Save the Children, la cual se ha convertido en un referente mundial para la protección de la niñez. Desde 1998 ha estado trabajando en la problemática de la explotación sexual y el abuso infantil, teniendo como líneas de trabajo la incidencia política, la sensibilización social y la formación de profesionales que coadyuven en la solución de la problemática o al menos permitan mitigar las terribles consecuencias en la vida de los niños víctimas del maltrato (Save the Children, s. f.).

En Colombia, desde el 2003 y a través del el Ministerio de Protección Social se ha venido implementando la "Política Nacional de Salud Sexual y Reproductiva" (Ministerio de Proteccion Social, 2003), con apoyo del ICBF, la Fiscalía, la Policía Nacional, el Ministerio de Justicia, el CTI, la Defensoría del Pueblo y los entes regionales; para este fin, el Estado colombiano creó el "Comité Interinstitucional Consultivo para la Prevención de la Violencia Sexual y Atención Integral de los Niños, Niñas y Adolescentes Víctimas del Abuso Sexual, mediante la Ley 1146 de 2007" ( Ley 1146 Congreso de la republica de Colombia, 2007,art,3).

En este contexto, la justicia colombiana tiene hoy el gran reto de ofrecer a las víctimas una adecuada asistencia, conforme a lo establecido por los estándares internacionales, de tal forma que 
sea realmente atendida su problemática y el daño causado por los actores de esta; y de igual manera sean reparados con su derecho a la justicia y a la verdad.

Dentro de la categorización por tipo de las víctimas existen las que han sido objeto de violencia sexual y que, por tratarse de NNA, deben ser tenidas en cuenta de manera especial como lo establece el artículo 44 de la Constitución Nacional y las diferentes Cortes colombianas.

Actualmente, Nacional e internacionalmente, se han endurecido aún más las penas por este tipo de delitos. No obstante, sigue siendo alta la tasa de abusos, y los mecanismos para evitarlos no han sido lo suficientemente efectivos.

Como se puede observar en la Tabla 1, el número de exámenes médicos por abuso sexual infantil entre 2005 y 2011 aumentó.

\section{Tabla 1}

Número de exámenes médicos por presunto abuso sexual 2005-2011.

\begin{tabular}{|l|l|l|}
\hline Rango de edad & 2005 & 2011 \\
\hline $0-4$ & 2.863 & 3.645 \\
\hline $6-11$ & 5.358 & 7.384 \\
\hline $0-17$ & 13.846 & 19.617 \\
\hline
\end{tabular}

Fuente: Instituto Colombiano de Bienestar Familiar (ICBF). (2012). Informe Nacional del Sistema de Información Misional.

Boyacá, aunque no está considerado como un departamento de alto riesgo para los menores, no está exento de esta problemática ya que para 2017 se presentaron, según la Defensoría del Pueblo y el Instituto de Medicina Legal, 275 casos de denuncias.

Boyacá está situado en la zona centro del país, en la cordillera Oriental de los Andes. Cuenta con una superficie de $23.189 \mathrm{~km}^{2}$, lo que representa el 2,03\% del territorio nacional y una división política con 123 municipios. Limita por el norte con los departamentos de Santander y Norte de Santander, por el este con los departamentos de Arauca y Casanare, por el sur con Meta y Cundinamarca, y por el oeste con Cundinamarca y Antioquia (Instituto Geografico Agustin Codazzi, 2016). 
La población está repartida en la zona urbana $(51,49 \%)$ y rural $(48,51 \%)$; la economía es principalmente agropecuaria. Según indica el Observatorio Nacional, a nivel regional en Boyacá para el año 2005 se reportaron solamente 33 casos de abuso sexual intrafamiliar; sin embargo, con el tiempo el número de víctimas ha ido aumentando considerablemente, razón por la cual este estudio trata de analizar por qué se ha incrementado en el departamento el ASI, dado que Boyacá era uno de los departamentos con más bajo índice en este flagelo.

A partir de 2012 cuando se reportaron 748 casos (149 pertenecientes al género masculino y 599 al género femenino), las cifras han ido en aumento de acuerdo con el Observatorio Nacional, la Defensoría del Pueblo y el ICBF. Así, en 2018 hubo un incremento del 34 \%, según reportes de estas entidades.

Tabla 2.

Exámenes médico-legales por presunta violencia sexual en Boyacá

\begin{tabular}{|c|c|c|c|c|c|c|c|}
\hline cotateo onst & 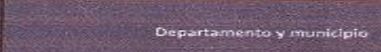 & $\cos \theta \operatorname{sen}$ & reaces & coros & $=0$ & $\cos 200$ & trove \\
\hline 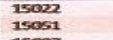 & nom & $=$ & $\infty \infty$ & & nem & & 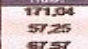 \\
\hline 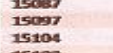 & $=$ & 1 & 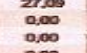 & & 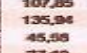 & & 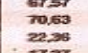 \\
\hline 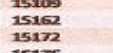 & $=$ & $\overline{3}$ & 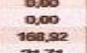 & 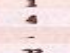 & 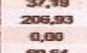 & 3 & 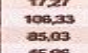 \\
\hline 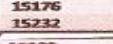 & Covoun & 2 & 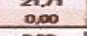 & 3 & & & 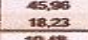 \\
\hline $\begin{array}{l}1 \text { sisas } \\
\text { sises }\end{array}$ & 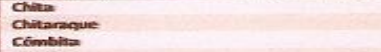 & $=$ & 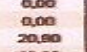 & & 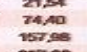 & 20 & 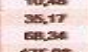 \\
\hline 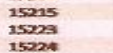 & 等 & 1 & 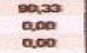 & 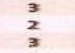 & 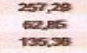 & & 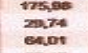 \\
\hline 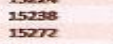 & $=$ & $=$ & 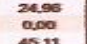 & $\frac{m}{2}$ & 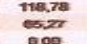 & & 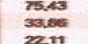 \\
\hline $\begin{array}{lll}15093 \\
1502006\end{array}$ & $=$ & $i$ & sioe & 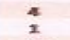 & $=0$ & $z_{2}^{3}$ & 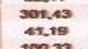 \\
\hline 100005 & 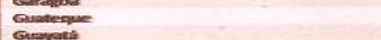 & & 趈我 & & 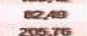 & & sins \\
\hline & $=$ & $=$ & 我禺 & $\stackrel{x}{*}$ & sing & & 2057 \\
\hline sisas & 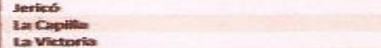 & $=$ & 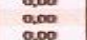 & & som & & $\sin _{\infty \rightarrow \infty}$ \\
\hline tistoss & $=$ & $\overline{5}$ & 我我 & $i$ & wis & $i_{2}^{4}$ & 我里 \\
\hline 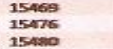 & $=$ & & 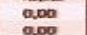 & & 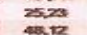 & & 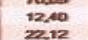 \\
\hline $\begin{array}{l}150509 \\
15090\end{array}$ & $=\infty$ & $=$ & 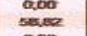 & $\frac{3}{2}$ & $\sin _{\infty \rightarrow \infty}$ & & $\begin{array}{l}\text { sase } \\
\text { sase }\end{array}$ \\
\hline 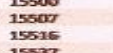 & somes & $\frac{1}{2}$ & 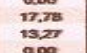 & 6 & 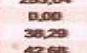 & & 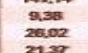 \\
\hline 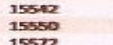 & $=0$ & 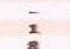 & 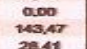 & $x_{3}^{1}$ & 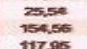 & $\sum_{0}^{2}$ & 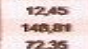 \\
\hline 105000 & $=$ & i & 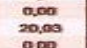 & 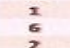 & 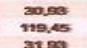 & & 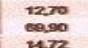 \\
\hline 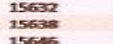 & sons & 1 & 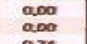 & 3 & sir & 3 & 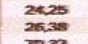 \\
\hline 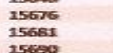 & 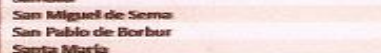 & $=$ & 步 & $\frac{2}{4}$ & 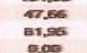 & $\frac{2}{4}$ & 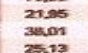 \\
\hline 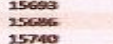 & $=$ & 2 & 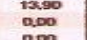 & $\begin{array}{l}1 \\
5 \\
5\end{array}$ & 集 & $\frac{2}{5}$ & 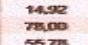 \\
\hline 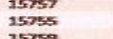 & schers & $=$ & $\infty \frac{\infty}{\infty \infty \infty}$ & $z$ & $\begin{array}{lll}\infty \\
\infty 200\end{array}$ & & 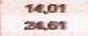 \\
\hline 157728 & $s=$ & $\therefore$ & 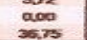 & $\frac{3}{2}$ & 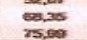 & $\frac{1}{3}$ & 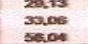 \\
\hline 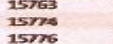 & 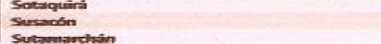 & 2 & 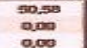 & $i$ & 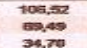 & $\frac{5}{1}$ & 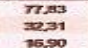 \\
\hline 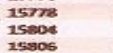 & $\begin{array}{l}\sum_{n=1}^{n=1} \\
\text { nom }\end{array}$ & : & 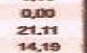 & $\begin{array}{c}1 \\
\frac{1}{5} \\
s\end{array}$ & 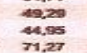 & $\frac{1}{3}$ & 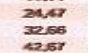 \\
\hline 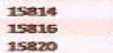 & sion & $\approx$ & 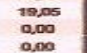 & $\frac{2}{3}$ & 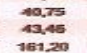 & . & 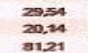 \\
\hline 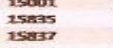 & 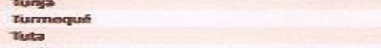 & $\frac{13}{x}$ & 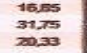 & $\frac{1}{2}$ & 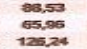 & 3 & 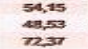 \\
\hline 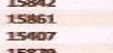 & $=0$ & $\frac{2}{2}$ & 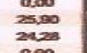 & $\frac{2}{6}$ & 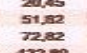 & $\frac{1}{3}$ & 象es \\
\hline
\end{tabular}


Fuente: Instituto Nacional de Medicina Legal y Ciencias Forenses / Grupo Centro de Referencia Nacional sobre Violencia / Sistema de Información Nacional de Estadísticas Indirectas.

Según el informe anual 2012 del Instituto Nacional de Medicina Legal y Ciencias Forenses - INMLCF,

En el departamento de Boyacá se realizaron 200 exámenes legales por presunto delito sexual a niños y niñas menores de 5 años, y un número similar de exámenes por violencia sexual a niños de 6 a 11 años, entre 2005 y 2011 (Instituto Nacional de Medicina Legal y Ciencias Forenses - INMLCF, 2012).

Es evidente entonces que existe una problemática bastante grave y que los mecanismos implementados por el Gobierno colombiano no parecen frenar el problema, ni que los medios judiciales que han incrementado las penas hayan logrado que los índices de violencia sexual contra los NNA se reduzcan.

Se hace necesario entonces un replanteamiento de los mecanismos con los que cuenta el Estado colombiano para lidiar con la violencia sexual en contra de los NNA, ya sea reforzando las políticas públicas, o el endurecimiento de penas u otros elementos que permitan que se efectivice la protección a los NNA víctimas de violencia, para que los afectados tengan la posibilidad de una verdadera justicia en la cual sus derechos sean plenamente reconocidos y respetados.

De acuerdo con lo anterior, se hace necesario analizar la situación del ASI en Boyacá teniendo en cuenta las víctimas, los esfuerzos del Estado y el proceso judicial para determinar ¿cuál es la situación en Colombia y especialmente en Boyacá de los NNA víctimas del ASI especialmente en el proceso judicial y de acuerdo con las políticas públicas? La respuesta a este interrogante será la base de esta investigación.

En consecuencia, se analizarán variables como la aplicación de los estándares internacionales, las dificultades del Estado para cumplir su función protectora, la labor de los operadores judiciales y cuales han sido las políticas públicas en la erradicación del ASI contra los NNA.

La hipótesis principal de la investigación fue determinar que las víctimas de ASI en Colombia y Boyacá siguen estando desprotegidas ante el avance de este delito en razón a que las políticas existentes no cumplen el cometido para las cuales fueron creadas y los operadores judiciales no aplican en determinados casos la rigurosidad requerida para que este flagelo pueda ser detenido y erradicado además que en muchos casos desconocen los estándares internacionales 
aplicables en materia de protección de los niños y adolescentes, a pesar de implementarse nuevas leyes e incrementar las penas además que algunas autoridades no tienen la debida diligencia al momento de presentar los casos y evaluar los testimonios de las víctimas.

De acuerdo con lo anterior, será el objetivo general de la investigación hacer una aproximación a la problemática del ASI, tomando como base el departamento de Boyacá; para establecer cuál es la situación de las víctimas frente al proceso judicial y por qué a pesar de los esfuerzos normativos y jurisprudenciales no se ha logrado la debida protección de las víctimas de ASI y por ende la disminución del delito de esta problemática tanto en el departamento como a nivel nacional.

Para desarrollar el objetivo general se adelantarán las siguientes acciones, que se irán desarrollando a través de los diferentes capítulos.

- Indagación de los estándares internacionales para la protección jurídica de la población víctima del ASI.

- Determinación de los estándares internos fijados en la normatividad, teniendo en cuenta los elementos legislativos y jurisprudenciales, el bloque de constitucionalidad y demás elementos existentes para la protección a dicha población.

- Conocer las políticas públicas colombianas aplicables en materia de protección y prevención a las víctimas de violencia sexual y ASI.

- Analizar el desarrollo procesal de los casos presentes en Boyacá en cuanto hace a los NNA víctimas de ASI, teniendo en cuenta aspectos como las actuaciones de los diferentes operadores judiciales, los lineamientos establecidos por los estándares internacionales y la aplicación de la legislación y jurisprudencia colombiana.

- Establecer las consecuencias tanto de orden Psicológico como social que el ASI produce en las victimas

- Adelantar conclusiones y elaborar propuestas que permitan visibilizar aún más la problemática del ASI. 
Dentro de la estructura de la presentación del trabajo hay cuatro capítulos. En el Capítulo 1 se abordará el ASI, así como las definiciones y los conceptos que harán parte del estudio y desarrollan el marco teórico. En el Capítulo 2 se incluyen tanto los estándares nacionales como los internacionales aplicables a la temática de la violencia sexual y el ASI en los NNA. El Capítulo 3 contiene lo correspondiente a Boyacá, y es la base de la investigación, en él se realiza el análisis del universo de sentencias de ASI obtenidas de la relatoría del Tribunal Superior del Distrito Judicial de Tunja y constituye la fundamentación que nos permite responder la pregunta de la investigación y conceptualizar las conclusiones finales del trabajo que se muestran en el Capítulo 4.

\section{Metodología}

La investigación de este trabajo se realizó de acuerdo con los lineamientos y presupuestos indicados en el módulo 56 (Universidad Santo Tomás, 2008), el proceso se dividió en tres etapas básicas que incluyeron a) la planeación del trabajo, b) su ejecución, y finalmente c) la consolidación y sintetizacion del mismo.

En la primera etapa se ajustó el proyecto de investigación en aspectos como el tema la ubicación geográfica, y el tiempo de realización que permitieron trazar la ruta metodológica para el desarrollo y la consecución del objetivo propuesto.

En la segunda etapa se realizó la revisión y extracción del material teórico documental de las diferentes fuentes utilizadas como libros, revistas, información de Internet e informes de diferentes entidades nacionales y extranjeras, normatividad y jurisprudencia de las distintas Cortes tanto nacionales como internacionales que nos permitieron construir y consolidar el análisis del trabajo.

Una vez obtenido el material se organizó y categorizo procediéndose a realizar los diferentes análisis requeridos del mismo, para finalmente y como última etapa consolidar y sintetizar la información con la cual se obtuvo el resultado y se respondió la pregunta formulada al comienzo del trabajo.

La investigación que se adelanto fue de tipo cualitativo y descriptivo donde se buscaba identificar las situaciones de los afectados por esta problemática y corresponde a la técnica documental deductiva por haber tenido como sustento el análisis interpretativo del tema en estudio 
Teniendo como base esta premisa se realizó un estudio de 24 sentencias, de segunda instancia en donde también se tuvo en cuenta las correspondientes a las primera instancias lo que haría un total de 48 casos, con los que se analizara el proceso y la forma como se aplicaron las normas judiciales y la situación de las víctimas frente al proceso judicial y el cumplimiento de los estándares mencionados; las sentencias en estudio hacen parte de la base de datos de la relatoría del Tribunal Superior del Distrito Judicial de Tunja sala penal; el periodo de fallos abarca desde el año de 2011 hasta el tiempo suficiente para que se permita obtener la respuesta a la pregunta base del trabajo.

Para la ubicación del espacio geográfico se tomó a Boyacá como objeto del estudio, y se estableció cuál es la situación de las víctimas frente a esas políticas, y frente a los procesos judiciales adelantados.

\section{CAPÍTULO 1}

\subsection{MARCO TEÓRICO}

\subsubsection{El abuso sexual contra los NNA. Generalidades}

Martínez (1982) define el abuso sexual como toda acción que un adulto, hombre o mujer, le impone a un niño con el fin de lograr placer sexual, con o sin contacto.

Kempe (1976), fundador de la Sociedad Internacional para la Prevención de los Niños Abusados y Maltratados, lo define como:

"La implicación de un niño o de un adolescente menor en actividades sexuales ejercidas por los adultos y que buscan principalmente la satisfacción de estos, siendo los menores de edad inmaduros y dependientes y por tanto incapaces de comprender el sentido radical de estas actividades y dar su consentimiento real" (Kempe, 1978 citado por Barudy, 1998: 161).

En Colombia viene definido por el artículo 2 de la Ley 1146 de 2007, que estipula lo siguiente: 
Se entiende por violencia sexual contra niños, niñas y adolescentes, todo acto o comportamiento de tipo sexual ejercido sobre un niño, niña o adolescente, utilizando la fuerza o cualquier forma de coerción física, psicológica o emocional, aprovechando las condiciones de indefensión, de desigualdad y las relaciones de poder existentes entre víctima y agresor “(Congreso de la República de Colombia, 2007, Ley 1146, art. 2).

Dice el Ministerio de Salud y Protección Social que

El Abuso Sexual Infantil (ASI) se define de múltiples formas tales como: todas aquellas acciones conscientes o inconscientes ejercidas por el abusador, a nivel físico y psíquico sobre la víctima, quien teniendo en cuenta su desarrollo no siempre está en condiciones de comprender esta actividad (Besten, 1997, citado en Almonte, Insunza y Ruiz, 2002). Así como cualquier contacto, acto, insinuación o amenaza que degrade o dañe el cuerpo y la sexualidad de una niña, niño, adolescente (los NNA), y que atenta contra su libertad, dignidad, formación e integridad sexual; concepto que obviamente abarca cualquier daño o intento de daño físico, psicológico o emocional (citado en Abril, Abuso Sexual Infantil: Protocolo de protección integral en Colombia 2016)

Intebi (2011) en su libro Proteger, reparar, penalizar indica que "Es innegable que el abuso sexual tiene un efecto por sí mismo, que tiene como base los desequilibrios de poder, de conocimientos y de gratificación que existen entre el agresor y el niño o niña o adolescente". (Intebi, Proteger,reparar, penalizar, 2011)

Save de Children (2012) en su Manual de Formación sobre Violencia Sexual y Atención a las Víctimas expone "El abuso sexual genera un daño potencialmente dañino en la parte emocional en los niños ya que no son comportamientos consensuado, y si resultan con frecuencia ser causantes de posteriores traumas; dañan la relación entre la víctima y su entorno familiar o social; pueden resultar dolorosos, producen temor y confusión”.

Existen elementos que, según algunos estudiosos del tema, como Rodes (2011), permiten diferenciar un comportamiento sexual abusivo, de uno que no lo es. Elementos como: la existencia de poder sobre la victima que permite poder controlarla física o emocionalmente, el grado de conocimientos diferente del agresor y la victima lo que hace que esta no entienda a cabalidad lo que 
representa el acto y lo que este puede acarrear consecuentemente tanto física como mentalmente al producirse el abuso sexual, y las diferencias en la satisfacción obtenida: el agresor se satisface sexualmente, y la víctima no obtiene nada más que el miedo y la vergüenza.

En este contexto, según la Asociación Mujeres por la Salud (s.f), se consideran comportamientos abusivos los que van desde

Acciones que no suponen un contacto sexual como las proposiciones verbales o la exhibición de los órganos genitales, hasta la penetración anal o vaginal. Algunos de estos comportamientos son: exhibirse desnudo delante del menor con el fin de excitarse sexualmente; observar al menor vestirse o desvestirse o cuando está en el baño, orina, etc., con el mismo fin: tocarle, besarle, agarrarle; y forzarle a ver imágenes o películas, escuchar conversaciones sexuales, posar para fotografías, ver o presenciar actividades sexuales, sexo oral o vaginal, y ser sometido(a) a tratamientos médicos innecesarios (Asociacion de mujeres para la salud, s.f.)

Intebi (2007) en el documento Valoración de sospechas de abuso sexual infantil establece dos tipos de abuso sexual: el primero es el que denomina "Comportamientos sexuales sin contacto físico" y que consisten en:

Comentarios sexualizados hacia el niño o la niña (lo más frecuente es que se realicen en su presencia, sin embargo, el(la) agresor(a) puede realizar comentarios obscenos por teléfono, notas o cartas); exhibición de genitales frente al niño o la niña llegando, a veces, incluso a masturbarse delante de él o ella; el voyerismo (espiar la intimidad del niño, niña o adolescente); la exhibición de materiales pornográficos al niño, niña o adolescente (libros, revistas o películas, videos, DVD); y la inducción a que el niño, niña o adolescente se desnude 0 se masturbe delante del (la) agresor(a) (Intebi, www.serviciossocialescantabria.org, 2007).

El segundo corresponde a "Comportamientos con contacto sexual” que pueden ser realizados por encima o por debajo de la ropa, y que incluyen: "Tocamientos en las partes íntimas (genitales, glúteos, pechos), inducción a que el niño, la niña o adolescente realice tocamientos al (la) agresor(a), frotamiento de los genitales del (la) agresor(a) contra el cuerpo o la vestimenta del niño, la niña o adolescente" (Intebi, www.serviciossocialescantabria.org, 2007). 
A pesar de los esfuerzos del Estado, no ha sido posible disminuir el número de infracciones, pues a diario se reportan más casos de abuso sexual a menores, que se dan en el contexto tanto del entorno familiar como del cercano.

Según la Policía Nacional (PONAL, 2017) y el INMLCF (2012):

El $80 \%$ de los casos que son denunciados el agresor es conocido por la víctima, o pertenece a su entorno familiar, por lo que hay que fortalecer los canales de comunicación en los hogares ya que el riesgo, muchas veces, está al interior de la familia y de sus allegados más cercanos.

Según el Grupo Centro de Referencia Nacional sobre Violencia (CRNV) del INMLCF a través del Sistema de Vigilancia Epidemiológica de Lesiones de Causa Externa (SIVELCE), que es el que se encarga de recopilar la información relacionada con el ejercicio médico legal, "durante el año 2015 se realizaron 22.155 exámenes médico-legales por presunto delito sexual (Instituto Nacional de Medicina Legal y Ciencias Forenses, 2016)".

Tabla 3.

Exámenes médico-legales por presunto abuso sexual por edad 2015.

\begin{tabular}{|c|c|c|c|c|c|c|c|c|c|}
\hline \multirow[b]{2}{*}{ Grupo de edad } & \multicolumn{3}{|c|}{ Hombre } & \multicolumn{3}{|c|}{ Mujer } & \multicolumn{3}{|c|}{ Total } \\
\hline & Casos & $\%$ & $\begin{array}{c}\text { Tasa } x \\
100,000 \\
\text { hab. }\end{array}$ & Casos & $\%$ & $\begin{array}{l}\text { Tasa } x \\
100.000 \\
\text { hab. }\end{array}$ & Casos & $\%$ & $\begin{array}{c}\text { Tasa } x \\
100.000 \\
\text { hab. }\end{array}$ \\
\hline foo a 04) & 597 & 18,21 & 27,00 & 2.011 & 10,65 & 95,28 & 2.608 & 11,77 & 60,35 \\
\hline$(05$ a 09) & 1.269 & 38,70 & 58,29 & 4.162 & 22,05 & 199,95 & 5.431 & 24,51 & 127,53 \\
\hline (10 a 14) & 954 & 29,09 & 43,61 & 7.648 & 40,52 & 365,04 & 8.602 & 38,83 & 200,85 \\
\hline$(15$ a 17) & 245 & 7,47 & 18,44 & 2.295 & 12,16 & 180,05 & 2540 & 11,46 & 97,57 \\
\hline (18 a 19) & 46 & 1,00 & 5,17 & 509 & 2,70 & 59,77 & 555 & 2,51 & 31,86 \\
\hline (20a 24) & 68 & 2,07 & 3,10 & 876 & 4,64 & 41,80 & 944 & 4,26 & 21,99 \\
\hline$(25$ a 29$)$ & 34 & 1,04 & 1,70 & 479 & 2,58 & 28,54 & 513 & 2,32 & 12,96 \\
\hline$(30 a 34)$ & 28 & 0,85 & 1,61 & 308 & 1,63 & 17,08 & 336 & 1,52 & 9,49 \\
\hline (35 a 39) & 6 & 0,18 & 0,39 & 207 & 1,10 & 12,56 & 213 & 0,96 & 6,64 \\
\hline$(40 a 44)$ & 11 & 0,34 & 0,79 & 234 & 0,7 & 8,97 & 145 & 0,65 & 5,04 \\
\hline (45 a 49) & 6 & 0,18 & 0,44 & 96 & 0,51 & 6,36 & 102 & 0,46 & 3,54 \\
\hline (50 a 54) & 2 & 0,05 & 0,16 & 54 & 0,29 & 3,84 & 56 & 0,25 & 2,09 \\
\hline (55 a 59) & 6 & 0,18 & 0,57 & 31 & 0,16 & 2,65 & 37 & 0,17 & 1,67 \\
\hline (60 a 64) & 3 & 0,09 & 0,37 & 22 & 0,12 & 2,40 & 25 & 0,11 & 1,45 \\
\hline (65 a 69) & 2 & 0,06 & 0,33 & 15 & 0,08 & 2,15 & 17 & 0,08 & 1,30 \\
\hline$(70$ a 74$)$ & - & 0,00 & 0,00 & 8 & 0,04 & 1,58 & 8 & 0,04 & 0,86 \\
\hline (75 a 79) & 2 & 0,06 & 0,67 & 7 & 0,04 & 1.81 & 9 & 0,04 & 1,31 \\
\hline (80 y más) & - & 0,00 & 0,00 & 14 & 0,07 & 3,45 & 14 & 0,06 & 203 \\
\hline Total & 3.279 & 300 & 33,78 & 78.876 & 200 & 77,35 & 22.155 & 100 & 45,36 \\
\hline
\end{tabular}


Fuente: Instituto Nacional de Medicina Legal y Ciencias Forenses, Grupo de Referencia Nacional sobre Violencia, Sistema de Información de Clínica y Odontología Forense, Sistema de Información Nacional de Estadísticas Indirectas.

Según el CRNV (2016):

La edad media de las víctimas fue de 12,45 años y la edad modal de 13 años. En la distribución por sexo la edad media de los hombres valorados fue de 9,73 años y en las mujeres 12,93 años; el grupo quinquenal más afectado fue el de 10 a 14 años. (Instituto Nacional de Medicina Legal y Ciencias Forenses, 2016)

El INMLCF (2010), en su publicación Forensis, reporta que "durante el año 2010 se realizaron 15.053 exámenes medicolegales por presunto delito sexual en niños y niñas hasta los 17 años” (Instituto Nacional de Medicina Legal y Ciencias Forenses, 2016). Posteriormente el mismo instituto reportó para 2015 que "se realizaron 22.155 exámenes medicolegales por presunto delito sexual, en el mismo rango de edad" (Instituto Nacional de Medicina Legal y Ciencias Forenses, 2016).

También el INMLCF (2010) indica que:

La tasa es de 46 casos por cada 100 mil habitantes y un incremento de 1.040 casos con respecto al año anterior, siendo las mujeres las más afectadas con un 85,2 \%. En promedio durante este periodo se practicaron 60 valoraciones diarias (Instituto Nacional de Medicina Legal y Ciencias Forenses, 2016).

Asegura el INMLCF (2016) que:

Durante el año, se atendieron 17.908 casos de menores remitidos por denuncias de presunto abuso sexual, y en 2017 en tan solo tres meses se dio atención por aparente violación a 4.315 menores de 17 años, presentándose el mayor número de casos en niñas y niños entre los 10 y los 14 años; les siguen los que están entre 5 y 9, y hasta los bebés también son víctimas (Instituto Nacional de Medicina Legal y Ciencias Forenses, 2016). 
En las investigaciones llevadas a cabo por la Fiscalía General de la Nación (FGN, 2016) en desarrollo de algunos procesos judiciales, se ha podido establecer que "los principales responsables son personas que se ubican en la primera línea de cercanía (primos, tíos, amigos) y que en muchos casos los victimarios son menores de edad (Palomino, 2017).

\subsubsection{Políticas públicas colombianas contra la violencia sexual}

El Estado colombiano firmo y refrendo la Convención sobre los Derechos del Niño y, por esta razón, ha creado diferentes entidades e implementado instrumentos para combatir los actos relativos a los delitos sexuales, diseñando políticas orientadas en la prevención y superación de delitos sexuales.

La política pública en temas de infancia se enmarca en el Plan Nacional de Desarrollo y se refuerza por los compromisos adquiridos en la Convención Internacional sobre los Derechos del Niño aprobada por el Congreso de la República de Colombia, mediante la Ley 12 del 22 de enero de 1991, en la cual introduce un cambio en la concepción social de la infancia (Consejo Nacional de Politica Economica, Departamento de planeacion, Republica de Colombia, 2007).

Según la línea de política pública para la prevención y erradicación de la explotación sexual comercial de niñas, niños y adolescentes 2018-2028, el Estado colombiano fundamenta su política a este respecto en tres ejes, entre los cuales se incluye el de la atención integral de abuso sexual (Instituto Colombiano de Bienestar Familiar, 2018).

EJE 1. Promoción de Derechos, Prevención, Participación y movilización social.

Se refiere a propuestas programáticas integrales y estrategias, nacionales y territoriales, orientadas a reconocer y garantizar los derechos y evitar que las niñas, los niños y adolescentes sean víctimas de explotación sexual.

EJE 2. Atención y restablecimiento de derechos. El objeto es brindar una atención integral a niñas, niños y adolescentes víctimas de Explotación Sexual Comercial de Niños, Niñas y Adolescentes (ESCNNA) para asegurar el restablecimiento de los derechos, la no repetición y evitar la revictimización en las rutas de atención intersectoriales.

EJE 3. Judicialización, vigilancia y control de los explotadores sexuales. Se ocupa de articular la institucionalidad estatal en virtud de garantizar el derecho a la justicia y reparación integral de niñas, niños y adolescentes que hayan sido víctimas de los delitos relacionados con explotación sexual comercial; así mismo, visibilizar y emprender 
estrategias útiles que permitan incrementar la denuncia y facilitar a operadores judiciales la investigación y condena de los victimarios (Instituto Colombiano de Bienestar Familiar, 2018).

Se entienden por políticas públicas de infancia y adolescencia, el conjunto de acciones que adelanta el Estado, con la participación de la sociedad y de la familia, para garantizar la protección integral de los niños, las niñas y los adolescentes" (Congreso de la República de Colombia, 2006, Ley 1098).

Las políticas públicas "se ejecutan a través de la formulación, implementación, evaluación y el seguimiento de planes, programas, proyectos y estrategias". (Ley 1098 de 2006 Congreso de la republica de Colombia, 2006, art. 201)

Así mismo, el artículo 202 de la Ley 1098 dispone como objetivos:

1) Orientar la acción y los recursos del Estado hacia el logro de condiciones sociales, económicas, políticas, culturales y ambientales, que hagan posible el desarrollo de las capacidades y las oportunidades de los niños, las niñas y los adolescentes, como sujetos en ejercicio responsable de sus derechos. 2) Mantener actualizados los sistemas y las estrategias de información que permitan fundamentar la toma de decisiones adecuadas y oportunas sobre la materia. 3) Diseñar y poner en marcha acciones para lograr la inclusión de la población infantil más vulnerable a la vida social en condiciones de igualdad. 4) Fortalecer la articulación interinstitucional e intersectorial. (Ley 1098 de 2006Congreso de la República de Colombia, 2006, Ley 1098, art.202).

En el artículo 203 de la Ley 1098 se establecen los principios rectores de las políticas públicas que, según el mismo artículo, se regirán como mínimo por los siguientes principios:

1. El interés superior del niño, niña o adolescente. 2. La prevalencia de los derechos de los niños, las niñas y los adolescentes. 3. La protección integral. 4. La equidad. 5. La integralidad y articulación de las políticas. 6. La solidaridad. 7. La participación social. 8. La prioridad de las políticas públicas sobre niñez y adolescencia. 9. La complementariedad. 10. La 
prioridad en la inversión social dirigida a la niñez y la adolescencia. 11. La financiación, gestión y eficiencia del gasto y la inversión pública. 12. La perspectiva de género (Congreso de la República de Colombia, 2006, Ley 1098, art,203).

En Colombia la política pública respecto a los NNA se orienta, a lograr que todos tengan condiciones básicas similares para vivir y desarrollarse, sin discriminación social, cultural o étnica.

Las políticas públicas en materia de protección infantil se articulan a través de los siguientes sistemas institucionales colombianos:

- Sistema Nacional de Bienestar Familiar (SNBF). Se define como "el conjunto de agentes, instancias de coordinación y articulación de relaciones existentes entre estos, para dar cumplimiento a la protección integral de los NNA y al fortalecimiento familiar" (Instituto Colombiano de Bienestar familiar, s.f.) desarrolla su labor a nivel nacional. Departamental, distrital y municipal

- Sistema de Protección Social. Es "el conjunto de políticas públicas orientadas a disminuir la vulnerabilidad y a mejorar la calidad de vida de los colombianos, especialmente de los más desprotegidos" (Congreso de la República de Colombia, 2002, Ley 789 articulo 1).

- Sistema Educativo. La educación en Colombia está a cargo del Ministerio de Educación Nacional y "establece las reglas aplicables al servicio público educativo" (Ley 115 de 1994 Congreso de la Republica de Colombia, 1994). Para este fin existen los establecimientos educativos (universidades, escuelas, colegios e institutos de formación como el SENA), en la educación descentralizada las Secretarias Municipales de Educación son las encargadas de trabajar conjuntamente con las autoridades municipales para el fin educativo y a nivel departamental la Secretaria Departamental.

- Sistema de Justicia. Según la Constitución nacional de 1991 (arts. 228-230), quien se encarga de administrar la justicia en Colombia es la rama Judicial; se compone de distintos órganos articulados del poder público destinado a dirimir conflictos conforme al derecho colombiano; de acuerdo a los tipos de proceso las jurisdicciones son: ordinaria, contenciosa administrativa, constitucional y la especializada (en temas de paz e indígenas). 
También hace parte de la estructura de la rama La Fiscalía General de la Nación, así como el Instituto de Medicina Legal y Ciencias Forenses.

Las defensorías de familia y el Instituto Colombiano de Bienestar familiar que son autoridades administrativas son piezas fundamentales y tienen competencia directa en la garantía de los derechos de los NNA, aunque no pertenecen al sistema de justicia sino a la rama ejecutiva.

Dentro de las políticas públicas en materia de infancia están:

\subsubsection{Documento Conpes Social 109, de diciembre de 2007}

Por medio de este documento se aprobó la Política Pública Nacional de Primera Infancia “Colombia por la Primera Infancia" (Consejo Nacional de politica Economica, 2007). Establece las líneas estratégicas sobre las cuales deberán orientarse las acciones de política pública en esta materia, las cuales son:

(I) Ofrecer apoyo integral a la primera infancia, (II) Mejorar la supervivencia y la salud de los niños y las niñas de 0 a 6 años y de las madres gestantes y en período de lactancia, (III) Mejorar los procesos de identificación en la primera infancia, (IV) Promover el desarrollo integral de la primera infancia, (V) Garantizar la protección y restitución de derechos, (VI) Mejorar la calidad de la atención integral, (VII) Fomentar la participación, (VIII) Realizar seguimiento y evaluación, (IX) Promover la comunicación y la movilización de la primera infancia, y (X) Promover la formación del talento humano y la investigación (Consejo Nacional de Política Económica Social , 2007).

Por otra parte, desarrolla lo preceptuado en el artículo 204 de la Ley 1098 de 2006, el cual indica:

“El Departamento Nacional de Planeación (DNP), el Ministerio de la Protección Social y el Ministerio de Educación Nacional, con la asistencia técnica del ICBF, deberá diseñar los lineamientos técnicos mínimos que deberán contener los planes de desarrollo en materia de infancia y adolescencia, teniendo en cuenta el ciclo de vida, el enfoque de garantía y el 
restablecimiento de derechos “(Congreso de la República de Colombia, 2006, Ley 1098, art. 204).

En ese sentido, el DNP publicó la cartilla Guía para Alcaldes. Marco para las Políticas Públicas y Lineamientos para la Planeación del Desarrollo de la Infancia y la Adolescencia en el Municipio, y para los candidatos que se presentaron a las elecciones de octubre de 2011, se desarrolló una cartilla que los orienta en la formulación de sus planes de gobierno (Departamento Nacional de Planeacion, 2007).

\subsubsection{Plan Nacional para la Niñez y la Adolescencia 2009-2019}

Contiene el compromiso del país con la infancia y adolescencia, a través de 12 objetivos que trataran de lograr en un lapso de 10 años, hasta 2019.

Este plan tiene como propósito que ningún NNA sea sometido a ningún tipo de abuso o maltrato y que su erradicación permita a los NNA crecer en mejores ambientes seguros y en pleno ejercicio de sus (Departamento Nacional de Planeación, 2009).

La Ley 1146 de 2007 crea en su artículo tercero crea el "Comités Interinstitucionales Consultivos para la prevención de la violencia sexual y la atención integral en niños, niñas y adolescentes víctimas del abuso sexual” ( Ley 1146 Congreso de la republica de Colombia, 2007).

A nivel departamental, se han establecido espacios y redes interinstitucionales que operan por medio de los Comités de Política Social, Mesas de Infancia y Adolescencia, Redes de Buen Trato, Mesas de Salud Mental, de Salud Sexual y Reproductiva o Redes Interinstitucionales específicas para el tema de la violencia sexual (Ministerio de Salud Republica de Colombia, 2011).

Como estrategia de atención intersectorial, en algunas ciudades fueron creadas las Casas de Justicia, los Centros de Atención Integral a Víctimas de Violencia Sexual (CAIVAS) y los Centros de Atención e Investigación Integral Contra la Violencia Familiar (CAVIF), con el fin de brindar atención intersectorial especializada a víctimas, en especial por parte de los sectores de protección y justicia (Fiscalia General de la Nacion, 2006).

En noviembre de 2014, se creó el Centro de Atención Penal Integral a Víctimas (CAPIV),

Como una estrategia de articulación interinstitucional de garantía a la administración de justicia en un mismo espacio, entre la Secretaría de Integración Social, la Fiscalía General 
de la Nación, la Alcaldía Mayor de Bogotá, la Policía Nacional, Medicina Legal y la Secretaría de la Mujer, entre otras entidades (Fiscalía General de la Nación, 2014, Resolución 1948).

El Fiscal General Luis Eduardo Montealegre en el acto de inauguración del CAPIV en noviembre de 2014 expuso que:

"El CAPIV es un espacio físico que responde a un modelo de atención en el que se incorporan todos los estándares de atención integral a las víctimas y se brinda la oferta institucional de las entidades que por ley cumplen funciones sociales y de protección a las víctimas, evitando la revictimización" (Secretaria Distrital de Integracion Social, 2014).

Actualmente en muchos municipios se cuenta con vías de atención intersectorial para la atención de víctimas de violencia sexual.

Podemos decir entonces que el Estado Colombiano preocupado por la problemática de la violencia sexual hacia los niños ha orientado sus políticas en esta materia teniendo en cuenta que los NNA son sujetos de derechos y actores sociales y debe garantizárseles esos derechos

\subsubsection{De Cero a Siempre}

Esta política de Estado fue convertida en ley de la República en agosto de 2016, y

"Es la Política de Estado para el Desarrollo Integral de la Primera Infancia, que busca aunar los esfuerzos de los sectores público y privado, de las organizaciones de la sociedad civil y de la cooperación internacional en favor de la Primera Infancia de Colombia” (Consejería Presidencial para la Primera Infancia, 2016).

Reúne los programas, servicios, proyectos, y acciones todo dirigido a la primera infancia, con el objetivo de ofrecer una real atención integral que efectivice y haga realidad que los niños entre 0 y 5 años puedan ejercer sus derechos.

De acuerdo con los tratados internacionales de los cuales Colombia hace parte, tanto el Estado como la familia, y por ende la sociedad tienen la obligación de garantizar la protección, salud, nutrición y educación desde el momento de la gestación hasta los 5 años. 
La política "De Cero a Siempre coordinará todas las instituciones, tanto públicas como privadas, para lograr garantizar una atención integral a 2.875 .000 niños y niñas" ( Comisión Intersectorial para la Atención Integral de la Primera Infancia , 2016).

De acuerdo con lo expuesto, se puede ver que existen aspectos por revisar, pues si bien las políticas públicas que se vienen desarrollando en Colombia en pro de la infancia y su protección, Buscan que las instituciones que trabajen en favor de la familia y la niñez en conjunto con la activa participación de la comunidad y las personas cumplan con el objetivo con el que fueron creadas o los mandatos que les fueron asignados y que implementen los programas y servicios que permitan garantizar y hacer respetar los derechos humanos y la protección integral de los niños y niñas; se hace necesario reforzar la protección del(a) niño(a) y adolescente contra cualquier forma de violencia, y especialmente el ASI, a fin de garantizar su seguridad y lograr así un mejor desarrollo psicosocial para los mismos (Departamento Nacional de Planeación, 2009).

Es claro que el Estado no ha podido cumplir plenamente con estos propósitos, pues aparte de algunos esfuerzos que realiza el ICBF y las comisarías de familia en el acompañamiento a las víctimas del ASI, la ayuda del Gobierno nacional es casi nula, pues así se tengan protocolos y rutas de atención, estos no funcionan por la falta de destinación de recursos para la financiación de estos sectores.

Según la Organización Mundial de la Salud (OMS), la política pública que se desarrolle en cualquier país debe estar en concordancia con el Código de los Niños y Adolescentes y será orientada primordialmente a dar la protección integral necesaria y a considerar a los NNA como grupos vulnerables y sujetos de derechos.

Colombia en sus políticas públicas tiene un componente que incluye protección contra la violencia infantil, pero no tiene realmente un componente específico para el ASI, considerada una de las formas de violencia sexual que está afectando gravemente a los NNA en el país.

De acuerdo con las políticas para la protección de la infancia y la adolescencia, en materia de prevención, la normatividad obliga de manera urgente integrar los "subcomités de infancia y familia, las redes del buen trato, las mesas de niñez y adolescencia, los modelos integrales de atención a víctimas de violencia sexual y violencia intrafamiliar" (Ministerio de salud y proteccion social); no obstante, en la práctica las entidades terminan trabajando de manera independiente ya 
sea porque no se crean los espacios necesarios para la interacción o, como en el caso de municipios lejanos, porque la ayuda estatal no llega nunca para implementar la logística.

Un claro ejemplo es que aunque existen diferentes protocolos de atención a víctimas de abuso sexual, únicamente hay un protocolo denominado "Modelo de intervención integral en casos de abuso sexual infantil" (Ministerio de salud republica de Colombia 2011), en el cual se contemplan una serie de acciones por ser realizadas, pero que nunca se llevan a cabo porque no se cuenta con los recursos necesarios, por tanto la atención se reduce a la denuncia y al acompañamiento en la fase inicial por parte de la comisaría de familia y el ICBF.

Tales acciones son la lucha contra el ASI, en coordinación con otras redes de apoyo o entidades de cualquier tipo que trabajen en pro del bienestar de los NNA; fomentar la prevención y procurar la detección del abuso, identificando factores de riesgo, atendiendo de forma eficiente a la víctima, lo que significa "desplegar las acciones de acogida, de exploración clínica, anamnesis, examen físico, tratamiento y prevención de infecciones de transmisión sexual; la atención psicosocial a la víctima y su familia" (Ministerio de Salud Republica de Colombia, 2011); informar el caso al ICBF y presentar la denuncia, además realizar la correspondiente intervención terapéutica requerida (diagnostico e intervención Psicológica o psiquiátrica).

\subsubsection{El proceso judicial, en los casos del ASI en los NNA}

Las normas colombianas han venido realizando un proceso de ajuste con el fin de modificar la normatividad y hacerla más acorde frente al problema que está generando el ASI.

El delito se encuentra tipificado en el Código Penal como un medio para tratar de combatirlo se endurecen las penas para los agresores; además, a través de diferentes leyes se impone la protección reforzada al menor y se pone de manifiesto el interés superior del niño, de acuerdo con los tratados internacionales y especialmente la Convención de los Derechos del Niño.

Es importante entonces conocer el proceso judicial que se sigue en el caso del ASI, que en la normatividad colombiana y dentro de los organismos encargados de la justicia, se considera a esta conducta como violación.

El manual de la Fiscalía General de la Nación (2009), establece el proceso por seguir:

"La víctima o quien presente la denuncia puede elegir entre una estación de policía, una comisaría de familia o la Fiscalía. De allí será enviado a Medicina Legal para que sea 
confirmada su versión y el resultado debe ser enviado al organismo que lo solicitó en un plazo máximo de 3 días.

La denuncia se puede hacer acusando a un sujeto determinado, o acusando a un desconocido; una vez enviada la denuncia a la oficina de admisiones y registro, se hará una valoración del tipo de delito y se mandará a la unidad de previas y permanentes, donde se determina si la denuncia amerita que se abra una investigación del caso.

Una vez abierta la investigación, y según el delito, el caso es enviado a la unidad que corresponda. Cuando es una violación, el proceso llega a cualquiera de las tres unidades de vía encargadas de los delitos que atentan contra la vida, la libertad y el pudor sexual (juzgado de menores, Fiscalía o ICBF)" (Fiscalia General de La nacion Colombia, 2009).

"Si la indagatoria no fue realizada, el fiscal asignado por el coordinador debe llevarla a cabo; en el caso contrario, tomará la ampliación de la denuncia por parte de la víctima, el victimario y los testigos (si los hay). El paso siguiente es realizar la resolución de la situación jurídica. A partir de ese momento empieza la recolección de pruebas hasta que el fiscal califique el proceso" (Fiscalia General de La nacion Colombia, 2009).

"Una vez calificado el proceso, se envía al juzgado penal del circuito donde se inician las diligencias del juzgamiento, con dos posibilidades: llamamiento a juicio, en el que se dicta la sentencia; y sobreseimiento temporal o definitivo" (Fiscalia General de La nacion Colombia, 2009).

Sin embargo, dentro del proceso judicial se evidencian situaciones que no permiten que las víctimas obtengan en la materia de los casos una verdadera justicia. Dentro de estas están:

Los operadores judiciales no cuentan con grupos interdisciplinarios especializados que incluyan psicólogos o trabajadores sociales que les permitan tener herramientas de apoyo para que en el tema de abuso sexual puedan tomar una decisión más justa para las víctimas de la agresión y no terminen favoreciendo al agresor.

El Estado, por otra parte, tampoco contempla un programa para la capacitación de los operadores judiciales (fiscales, jueces y funcionarios de policía judicial) que manejan estas conductas punibles, para su sensibilización y conocimiento de la temática real del ASI.

Entonces así se promulguen más leyes o se endurezcan las penas, nada de esto será suficientemente efectivo, hasta tanto el Estado no invierta recursos en la prevención del ASI y en la 
formación de los operadores judiciales que permita que sus decisiones favorezcan a la víctima y no al victimario.

Además, es urgente incorporar en nuestra cultura y en todas las esferas sociales la formación en los derechos humanos y establecer políticas públicas, para la prevención y atención a los menores, pero que no se queden únicamente en el papel y las buenas intenciones, y por el contrario permitan un manejo preventivo más que sancionatorio.

A pesar de que Colombia ha adoptado los acuerdos y tratados internacionales para la protección de NNA, el país apenas ha hecho avances limitados en esos compromisos.

Lo anterior ocurre, ya que en las políticas de protección a los menores hay un cuello de botella en la implementación judicial y en la aplicación por parte de los operadores jurídicos de estos sistemas de protección a los menores.

Al examinar las cifras, los datos y los indicadores de infancia en Colombia y al realizar una comparación entre la situación de ayer con la de hoy, solo se encuentran avances en el incremento de las penas, pero no una reducción significativa de los casos de ASI en los NNA.

Prueba de esto lo constituyen las leyes 599 de 2000, o Código Penal; la Ley 1236 de 2008, que modifico algunos artículos relativos a delitos de abuso sexual; y la Ley 1146 de 2007, que busca prevenir la violencia sexual mediante la expedición de normas al respecto e incluye la atención integral de los NNA abusados sexualmente.

Es preocupante ver que, con respecto a los procesos de rehabilitación y resocialización de las víctimas, no se encuentra bien definido, e inclusive los protocolos del ICBF no son suficientes para dar la atención integral de los NNA víctimas del abuso sexual.

De acuerdo con la legislación nacional e internacional se debe propender por evitar la revictimización (Rochel, 2005; Palomero, 2007; Unicef, 2009) y garantizar el cumplimiento de los derechos de los NNA (ICBF, 2006); sin embargo, en los estrados judiciales estos preceptos no se cumplen y por ejemplo un proceso judicial conlleva años, en los cuales la víctima no puede olvidar la agresión porque siempre está expuesta por ser parte del proceso (revictimización).

El Abuso Sexual Infantil (ASI) se define de múltiples formas como: todas aquellas acciones conscientes o inconscientes ejercidas por el abusador, a nivel físico y psíquico, sobre la víctima, quien teniendo en cuenta su desarrollo no siempre está en condiciones de comprender esta actividad (Besten, 1997 citado en Almonte, Insunza y Ruiz, 2002) (Abril, Abuso Sexual Infantil : Protocolos de Proteccion Integral en Colombia) en , así como 
Cualquier contacto, acto, insinuación o amenaza que degrade o dañe el cuerpo y la sexualidad de una niña, un niño, adolescente (los NNA), y que atenta contra su libertad, dignidad, formación e integridad sexual; concepto que obviamente abarca cualquier daño o intento de daño físico, psicológico o emocional (Fiscalía General de la Nación, 2010 citado en Ministerio de la Protección Social, 2011) (Ministerio de Proteccion Social ¡, Colombia).

De acuerdo con las políticas de "protección de la infancia y la adolescencia" (Departamento Nacional de Planeación, 2007), en materia de prevención, la normatividad obliga de manera urgente “integrar los subcomités de infancia y familia, las redes del buen trato, las mesas de niñez y adolescencia, y los modelos integrales de atención a víctimas de violencia sexual y violencia intrafamiliar" (Departamento Nacional de Planeacion, 2007).

No obstante, en la práctica las entidades terminan trabajando de manera independiente ya sea porque no se crean los espacios necesarios para la interacción o, como en el caso de municipios lejanos, porque la ayuda estatal no llega nunca para implementar la logística.

En cuanto al proceso judicial, el Estado tampoco contempla un programa para la capacitación de fiscales, jueces y demás operadores judiciales que hacen parte del manejo de estas conductas criminales; no existen grupos interdisciplinarios especializados que incluyan psicólogos o trabajadores sociales que permitan que el operador judicial cuente con herramientas de apoyo que le posibiliten tomar decisiones más justas en los casos del ASI y no terminen favoreciendo al agresor.

Entonces, así se promulguen más leyes o se endurezcan las penas, nada de esto será suficientemente efectivo, hasta tanto el Estado no invierta recursos en la prevención del ASI y en la formación de los operadores judiciales, que permita que sus decisiones favorezcan a la víctima y no al victimario. 


\section{CAPÍTULO 2}

\subsection{ESTÁNDARES INTERNACIONALES Y NACIONALES EN MATERIA DE PROTECCIÓN JURÍDICA A LA POBLACIÓN VÍCTIMA DE VIOLENCIA SEXUAL}

\subsubsection{Estándares internacionales}

Dentro de los mecanismos para proteger los niños contra la violencia sexual se tienen tratados que establecen obligaciones para ser incorporados por los Estados en sus legislaciones, sus mecanismos de supervisión, las directrices para una implementación eficaz y las estrategias para lograr que el compromiso adquirido sea totalmente efectivo.

Y es que cuando se trata de la protección de los NNA contra esta forma de violencia, la intervención se debe realizar tanto a nivel local como internacional, incluyendo tanto a la familia y a los entornos sociales, educativos, sanitario y judicial, y desde el punto de vista del legislativo y de políticas públicas.

Es innegable que cualquier forma de violencia sexual que se ejerza en contra de los NNA entraña un problema social que conlleva repercusiones en su vida, en su ámbito de desarrollo y en todos y cada uno de los contextos en los que la víctima se desarrolla.

\section{Según la UNICEF,}

La dificultad para atacar este problema en algunos países se da porque en los "sistemas jurídicos estatales" no se dispone de "recursos suficientes para proceder con eficacia y rapidez contra los autores de delitos sexuales con menores y por lo tanto se dificulta ostensiblemente llevar a la práctica los derechos garantizados a los niños" (UNICEF, 2013).

La comunidad internacional ha venido trabajando arduamente en pro de una protección eficaz contra la violencia sexual de los NNA; un reflejo de este esfuerzo está plasmado en numerosos documentos y mecanismos internacionales que demuestran cómo se integra la comunidad internacional en esta lucha. 
Dentro de estos instrumentos están:

\subsubsection{El Sistema universal de protección de derechos humanos dentro del marco de las Naciones Unidas}

La Organización de las Naciones Unidas (ONU) “es una entidad de carácter internacional, integrada por gobiernos de todo el mundo que buscan unir esfuerzos para conseguir buenos resultados en materia de paz, seguridad, progresos tanto económicos como sociales, cuestiones humanitarias y de derechos humanos" (Perez, 2008).

Trabaja en pro de la niñez a través de la UNICEF, que es el Fondo de las Naciones Unidas para la Infancia, cuya principal finalidad es promover la protección de los derechos de los niños (ONU, s.f.).

Las Naciones Unidas han sostenido una lucha constante en pro de erradicar la violencia sexual en contra de los NNA. Así, se ha logrado implementar los siguientes instrumentos de importancia y aplicabilidad mundial:

\subsection{Convención sobre los Derechos del Niño (CDN)}

Fue adoptada por la "Asamblea General de las Naciones Unidas el 20 de noviembre de 1989 y aprobada en Colombia mediante la Ley 12 del 22 de enero de 1991” (OAS.org, s.f.).

Es el marco orientativo de las legislaciones nacionales. Fue adoptada por las Naciones Unidas y aprobada por la totalidad de la Asamblea General de la ONU; con esta se "reconoce a todos los niños y las niñas la titularidad de derechos humanos que atienden a su especial vulnerabilidad y necesidades de protección como seres humanos en desarrollo" (UNICEF, 2006).

En el artículo 1se define como niño "a todo ser humano menor de 18 años, salvo que, en virtud de la ley que le sea aplicable, haya alcanzado antes la mayoría de edad" (UNICEF, 2006).

Así mismo la Convención tiene unos protocolos complementarios, que proporcionan un marco jurídico con el fin que los Estados diseñen y adecuen su legislación interna y sus leyes orgánicas tendientes a proporcionar la debida protección a la población infantil; al ratificar la Convención sobre los Derechos del Niño, cada Estado adquiere el compromiso de reconocer e implementar los derechos incluidos en esta. 
La Convención sobre los Derechos del Niño contiene específicamente tres artículos referidos expresamente a la violencia contra los NNA (artículos 19, 34, 39). Particularmente, el artículo 19 exige

"Medidas legislativas, administrativas, sociales y educativas apropiadas para proteger al niño contra toda forma de perjuicio o abuso físico o mental, descuido o trato negligente, malos tratos o explotación, incluido el abuso sexual”, mientras se hallen bajo la protección de un adulto responsable del mismo (ONU, 1989).

En ese sentido,

1. "Los Estados Parte adoptarán todas las medidas legislativas, administrativas, sociales y educativas apropiadas para proteger al niño contra toda forma de perjuicio o abuso físico o mental, descuido o trato negligente, malos tratos o explotación, incluido el abuso sexual, mientras el niño se encuentre bajo la custodia de los padres, de un representante legal o de cualquier otra persona que lo tenga a su cargo" (Unicef, s.f.).

2. Esas medidas de protección deberían comprender, según corresponda, procedimientos eficaces para el establecimiento de programas sociales con objeto de proporcionar la asistencia necesaria al niño y a quienes cuidan de él, así como para otras formas de prevención y para la identificación, notificación, remisión a una institución, investigación, tratamiento y observación ulterior de los casos antes descritos de malos tratos al niño y, según corresponda, la intervención judicial (Unicef, s.f.)l.

En el artículo 32 numeral 1, se prohíbe la explotación sexual de los niños y establece "el derecho del niño a no ser explotado ni a realizar trabajos que no le permitan educarse correctamente y genere un daño tanto en su desarrollo físico o mental o en su salud" (ONU, 1989)

En el artículo 34 se encuentra el compromiso de los Estados Parte hacia la protección del niño para evitar cualquier forma de explotación y violencia sexual. En consecuencia, los Estados Parte deberán tomar todas las medidas de carácter nacional, bilateral y multilateral que se requieran para impedir: 
"La incitación o la coacción para que un niño se dedique a cualquier actividad sexual ilegal;

La explotación del niño en la prostitución u otras prácticas sexuales ilegales; La explotación del niño en espectáculos o materiales pornográficos” (ONU, 1989).

El artículo 39 promulga la obligatoriedad de los Estados de adoptar las medidas necesarias para que los menores y adolescentes víctimas de violencia sexual o cualquier otro tipo de violencia puedan tener una adecuada recuperación tanto física como psicológica que le permita vivir socialmente con una buena calidad de vida (ONU, 1989).

Sin embargo, y como lo señala Beloff (2014) en su comentario del artículo 19 de la Convención sobre los Derechos del Niño, "seguimos siendo protagonistas de una apropiación meramente retórica de los derechos humanos de la infancia sin mayor impacto en la realidad de las prácticas vinculadas con la protección a la niñez" (Beloff, 2014).

A la "Convención sobre los Derechos del Niño" se le puede considerar como el primer instrumento internacional vinculante jurídicamente en donde se incorporan todos los derechos humanos (civiles, culturales, económicos, políticos y sociales).

Dentro de la aplicación de los derechos humanos era muy importante que los niños gozaran de un instrumento que los protegiera y les garantizara sus derechos, razón por la cual se decidió a Nivel mundial por parte de los dirigentes de los países participantes dotar a los niños de un instrumento dirigido exclusivamente a ellos que les proporcionara una protección especial y fue así como se instituyo esta Convención.

Para asegurar el cumplimiento de la Convención y sus protocolos existe el "Comité de los Derechos del Niño (CRC, por su sigla en inglés)," el cual es un órgano de expertos independientes, quienes supervisan que en los Estados parte se aplique la "Convención sobre los Derechos del Niño" e igualmente sus dos primeros Protocolos (Protocolo facultativo que trata sobre la participación de los niños en los conflictos armados y el Protocolo facultativo relativo a la comercialización de niños, con fines de prostitución y pornografía.

Sobre el derecho de los NNA a no ser "objeto de ninguna forma de violencia", se publicó por parte del comité en 2011 la observación general número 13. Mediante este documento el Comité marca las pautas para entender en profundidad este derecho y la manera como debe ser interpretado el artículo 19 de la Convención. 


\subsubsection{2. "Protocolo Facultativo de la Convención sobre los Derechos del Niño relativo a la venta de niños, la prostitución infantil y la utilización de niños en la pornografía"}

Este protocolo se aprobó por parte de la Asamblea General el día 25 de mayo de 2000, y entró en vigor el 18 de enero de 2002, en Colombia se adoptó a través de la Ley 769 de 2002.

Este protocolo contempla la "prostitución infantil" y la utilización de menores en pornografía, que constituye una nueva forma de violencia contra los NNA.

De igual forma, la venta de niños debe entenderse como una forma de violencia y explotación infantil si está asociada a fines sexuales.

Establece el Protocolo que se considera violencia contra los NNA:" ofrecer, entregar o aceptar, por cualquier medio, un niño con fines de explotación sexual"; así como la producción, distribución, divulgación, importación o exportación, de material que involucre a NNA de igual manera se considera el vender o poseer el material antes señalado.

Incorpora el artículo tercero la obligatoriedad de los Estados Parte a "incluir dentro de su legislación penal los actos abusivos en contra de los niños" aun si se han cometido dentro o fuera de su territorio.

Así mismo, el artículo 4 del Protocolo requiere que en todos los Estados Parte persigan estos delitos, instituyendo las disposiciones que sean necesarias para realizar esta labor de forma efectiva.

Centra este Protocolo especialmente la atención en la criminalización de la comercialización de NNA, la prostitución infantil y el utilizar a estos en la producción pornográfica; y enfatiza que se debe fomentar una mayor concientización social y se debe reforzar la cooperación internacional para la eliminación de este delito.

El Protocolo Facultativo complementa la "Convención de los Derechos del Niño” y exige a las partes unos requisitos esenciales con el fin se terminar con la explotación y la violencia sexual de la infancia. 


\subsection{Convención para la Eliminación de todas las Formas de Discriminación contra la Mujer (CDAW)}

Dentro de los tratados internacionales de derechos humanos, la Convención ocupa un importante lugar por incorporar el enfoque de género al conjunto de los derechos humanos en sus distintas manifestaciones.

Pero la CDAW no es solo una declaración de derechos encaminados únicamente a la mujer, sino que contiene una serie de programas para logar que los Estados garanticen efectivamente esos derechos.

La CDAW (artículo 3) define a la mujer como objeto de la discriminación, por esto incita a los Estados Parte a que implementen

Todas las medidas apropiadas, inclusive de carácter legislativo para asegurar el desarrollo y adelanto de la mujer, con el objeto de garantizarle el ejercicio y el goce de los derechos humanos y las libertades fundamentales en igualdad de condiciones con el hombre (Naciones Unidas, Oficina del alto comisionado,1979)

Entre los artículos que comprende el texto de esta Convención (CEDAW), se destaca la igualdad de la mujer, concentrándose en tres aspectos básicos: como sus derechos civiles, y su condición socio jurídica; igualmente se ocupa de temas como la reproducción y las incidencias que factores de tipo cultural generan en las relaciones entre hombres y mujeres.

Dentro de la temática así mismo se abordan diferentes ámbitos en los cuales la mujer se desenvuelve. Algunos son: funciones estereotipadas y prejuicios, prostitución, educación, la mujer rural, igualdad ante la ley, matrimonio y familia.

También trata la planificación familiar, el tiempo entre los alumbramientos y el acceso a niveles de formación educacional para que ellas puedan acceder realmente a esos derechos.

La CDAW es legalmente vinculante, es decir que los países que la han aceptado tienen la obligación de cumplir el compromiso adquirido, por haberla firmado. Este compromiso incluye: implementar el principio de igualdad sin distingo de sexo; eliminar normas que permitan la discriminación y adoptar las necesarias para prohibir la misma; establecer tribunales que tengan como objetivo la protección de la mujer contra esa discriminación; y asegurar que se eliminen los actos de discriminación contra la mujer por parte de individuos, organizaciones y empresas. 


\subsection{Convenio 182 sobre las peores formas de trabajo infantil (Ley 704 de 2001)}

Adoptado por la OIT en 1999 y la Recomendación 90, que la complementa.

Su importancia reside en que abole la esclavitud infantil, el trabajo forzoso y prohíbe el tráfico de NNA.

El Convenio 182 en su artículo 1 considera que

La efectiva eliminación del trabajo infantil es tan imperiosa, que se ha vuelto obligatorio para los Estados miembros ratificantes, la adopción de medidas de carácter inmediato y que tengan eficacia para que se pueda llevar a cabo la prohibición y eliminación de las peores formas de trabajo infantil. (OIT, 1999).

También señala que el utilizar, reclutar u ofrecer niños para ser usados en la prostitución o en la pornografía constituye una de las peores formas de trabajo infantil.

Para una comprensión total del convenio 182 se debe tener en cuenta la Recomendación 190 de 1999 que trata de las peores formas de trabajo a que pueden ser sometidos los niños; ya que el fin de las recomendaciones es la de poder interpretar y aplicar en forma correcta los convenios y esta es la que corresponde al ya mencionado convenio.

\subsection{Protocolo para prevenir, reprimir y sancionar la trata de personas, especialmente de mujeres y niños}

La Asamblea General de las Naciones Unidas lo adopta e el 15 de noviembre de 2000 (Ley 800 de 2003) y se constituye en un complemento de la "Convención de Palermo contra la Delincuencia Transnacional Organizada" (Naciones Unidas, oficina contra la droga y el delito, 2000).

Es uno de los tres protocolos complementarios que se desarrollan en especial en materia de delitos organizacionales. Contiene normativa aplicable directamente a la ejecución y el manejo que deben adoptar los Estados Parte para la prevención, la represión y la sanción de los delitos de "trata de personas". 
Se incluyen en el Protocolo mecanismos que pretenden prevenir el delito de trata de personas, y que permitan sancionar este delito a nivel internacional fomentar la ayuda recíproca entre los Estados para que el proceso y objetivo en general sean realizables.

Se adhiere a la Convención de Palermo y establece la extrema necesidad de reunir en un solo cuerpo la normativa que protege a las mujeres y los niños de los delitos contrarios a la integridad humana y de trata de personas.

El artículo 2 del Protocolo especifica sus fines:

a) Prevenir y combatir la trata de personas, prestando especial atención a las mujeres y los niños; b) Proteger y ayudar a las víctimas de dicha trata, respetando plenamente sus derechos humanos; y c) Promover la cooperación entre los Estados Parte para lograr esos fines (ONU, 2000).

El Protocolo en su artículo 5 determina que cada Estado dentro de sus posibilidades y en cuanto lo aplicable "debe individualizar y aplicar las normas necesarias para penalizar y sancionar el delito de trata de personas" (ONU, 2000).

En el artículo 14, se establece una cláusula denominada de salvaguardia en las disposiciones finales, la cual establece que lo que se disponga en el protocolo no afectara de ninguna manera las obligaciones de los Estados y sus responsabilidades ni los derechos que estos preceptúen en conformidad con el derecho internacional humanitario en relación a las personas (ONU, 2000).

Esto hace referencia a las obligaciones que tiene el Estado de forma interna, y ningún aspecto internacional le inhibe de cumplirlos ante sus administrados.

En cuanto a los estándares internacionales del sistema universal de protección de derechos humanos de Naciones Unidas, se puede concluir que a nivel internacional son grandes los esfuerzos por reconocer a los menores como seres en desarrollo, derechos y cuidados especiales, todo a la luz del interés superior de estos; lo cual significa que tanto el Estado como la sociedad así como los que tienen bajo su cuidado los NNA están en la obligación de velar por que esos derechos estén garantizados y se cumplan a plenitud.

La protección para NNA está definida por la "Convención sobre los Derechos del Niño" y los diferentes protocolos y contiene el "principio del interés superior del niño y la niña" en la políticas internacionales y nacionales; así, es claro que los NNA tienen derechos que han sido 
introducidos por los Estados parte en su ordenamiento jurídico, a través de los acuerdos internacionales. El compromiso es entonces el de implementar medidas para la protección de esos derechos y el de no ser sometidos a la explotación sexual.

\subsubsection{Sistema Interamericano de Protección de los Derechos Humanos y especialmente de} los derechos de los NNA

No posee el "Sistema Interamericano de Protección de los Derechos Humanos" elemento alguno de tipo declarativo o convencional que de forma alguna establezca específicamente los derechos humanos relativos a los NNA en el continente.

No obstante, como si existen esos instrumentos a nivel internacional que contemplan expresamente la orden de dar protección especial a los NNA que no cumplan aun los 18 años; estos se utilizan en este sistema para garantizar la protección a que tienen derecho los NNA; teniendo como base el artículo 19 de la "Convención Americana sobre Derechos Humanos" que puede considerarse como la máxima expresión de la protección especializada con la que se deben cobijar los NNA.

Para cumplir con el propósito de velar por los NNA, la Organización de Estados Americanos (OEA) se apoya en los siguientes tratados:

Convención sobre los Derechos del Niño (CDN), adoptada por la Asamblea General de las Naciones Unidas el 20 de noviembre de 1989 y aprobada en Colombia mediante la Ley 12 del 22 de enero de 1991 (Congreso de la Republica de Colombia, 1991).

"Convenio 182, adoptado por la OIT en 1999, y la Recomendación 90 - que la complementasobre las peores formas de trabajo infantil (Ley 704 de 2001). Fija la abolición de prácticas como la esclavitud infantil, el trabajo forzoso y el tráfico de niños (ICBF, 2009).

Protocolo Facultativo de la Convención sobre los Derechos del Niño relativo a la venta de niños, la prostitución infantil y la utilización de niños en la pornografía, aprobado por la Asamblea General el 25 de mayo de 2000, que entró en vigor el 18 de enero de 2002, y fue adoptado por Colombia a través de la Ley 769 de 2002. (Naciones unidas Oficina alto comisionado, s.f.)

Protocolo para prevenir, reprimir y sancionar la trata de personas, especialmente de mujeres y niños, adoptado por la Asamblea General de la Naciones Unidas el 15 de noviembre de 2000 (Ley 
800 de 2003), que complementa la Convención de Palermo contra la Delincuencia Transnacional Organizada de diciembre de 2000 (Naciones Unidas, oficina contra la droga y el delito, 2000).

Además, en el Sistema Interamericano, a los niños se le reconocen sus derechos humanos en los siguientes instrumentos:

\subsubsection{1. "Declaración Americana de los Derechos y Deberes del Hombre"}

Fue aprobada en 1 IX Conferencia Internacional Americana, Bogotá, 1948.

El artículo 1 de la Declaración Americana comprende derechos tales como el derecho a la vida, a la libertad personal y a la seguridad, que se encuentran respectivamente reconocidos de forma autónoma por los artículos 4 y 7 de la Convención Americana.

El principal aporte de la Declaración Americana actualmente está en tener en cuenta el valor orientador en la protección de los derechos humanos. El valor jurídico de esta declaración se encuentra reconocido en su artículo 29, literal d) de la Convención Americana y por la Opinión Consultiva 10-89 de la Corte Interamericana de Derechos Humanos (CIDH).

Respecto a la protección infantil, el artículo VII establece que "toda mujer en estado de gravidez o en época de lactancia, así como todo niño, tienen derecho a protección, cuidados y ayuda especiales" (OEA,1948).

\subsubsection{2. "Convención Interamericana sobre Desaparición Forzada de Personas, Belem Do} Pará, Brasil, 9 de junio de 1994"

La Declaración sobre la protección de todas las personas contra las desapariciones forzadas señala en su preámbulo que "las desapariciones forzadas afectan los valores más profundos de toda sociedad respetuosa de la primacía del derecho, de los derechos humanos y de las libertades fundamentales, y que su práctica sistemática representa un crimen de lesa humanidad"(ONU, 1992).

Se expone en este documento que

Al realizarse una desaparición forzada se están violando múltiples derechos que son esenciales y pertenecen al ser humano en su calidad de persona, que estos derechos son inderogables acorde esto con lo consagrado en "la Convención Americana sobre Derechos Humanos, en la "Declaración Americana de los Derechos y Deberes del Hombre y en la “Declaración Universal de Derechos Humanos (OEA, 1994a). 
El artículo XII indica la necesidad que los Estados que hacen parte trabajen de forma mancomunada brindando toda la cooperación posible en la "búsqueda, identificación, localización y restitución de menores que hubieren sido trasladados a otro Estado o retenidos en este, como consecuencia de la desaparición forzada de sus padres, tutores o guardadores" (OEA, 1994).

\subsection{Protocolo Adicional a la Convención Americana sobre Derechos Humanos en Materia de Derechos Económicos, Sociales y Culturales "Protocolo de San Salvador"}

Fue suscrito el 17 de noviembre de 1988 en San Salvador y Aprobado por Colombia mediante la Ley 319 del 20 de septiembre de 1996 (Senado de la republica de Colombia, 1996).

En el artículo séptimo se reconoce que de acuerdo con el artículo sexto del mismo protocolo todas las personas tienen derecho al trabajo en igualdad de condiciones; para este fin los Estados incluirán dentro de su ordenamiento interno de manera especial, la no realización por parte de menores de 18 años de actividades laborales en horario nocturno o que pongan en riesgo su salud o su moralidad. Si el trabajador es menor de 16 años, primará la educación sobre el horario laboral y no podrá impedírsele su derecho a la instrucción. (OEA, 1988).

En el artículo 15. apartado 3. Se establece el compromiso de proteger al grupo familiar y que se garantice a los NNA tanto durante su época de lactancia como la de escolaridad una alimentación adecuada a sus requerimientos, para su normal desarrollo durante todo su proceso de crecimiento hasta lograr su plena madurez tanto física como intelectual. Así mismo se deben implementar programas especiales que involucren a la familia y se logre crear un ambiente propicio para el pleno desarrollo de los NNA con valores de comprensión, solidaridad, respeto y responsabilidad (OEA, 1988).

El artículo 16. Establece el derecho que tienen los NNA a ser protegidos por su entorno familiar social y del Estado, que son los padres quienes deben velar por el menor y que a no ser que se presente una situación excepcional un niño de corta edad no puede ser separado de la madre salvo que sea por orden judicial. También se establece el derecho a la gratuidad 
y obligatoriedad de la educación y el poder acceder a una formación educativa mayor (OEA, 1988).

\subsection{Carta Democrática Interamericana}

Aprobada el 11 de septiembre de 2001, en sesión especial de la Asamblea de la Organización de los Estados Americanos (OEA) en Lima (Perú) (OEA, 2016).

Tiene como objetivo principal fortalecer la institucionalidad democrática. El documento establece lo que se puede considerar como una democracia representativa, en donde existe el respeto a los derechos humanos, la separación e independencia de los poderes públicos y la libertad de expresión.

Dice la carta en el artículo 16, que la educación es clave para fortalecer las instituciones democráticas, promover el desarrollo del potencial humano y el alivio de la pobreza y fomentar un mayor entendimiento entre los pueblos. Para lograr estas metas, es esencial que una educación de calidad esté al alcance de todos, incluyendo a las niñas y las mujeres, los habitantes de las zonas rurales y las que pertenecen a las minorías (OEA, 2001).

De igual forma, el artículo 27 establece que los programas y las actividades se dirigirán a promover la gobernabilidad, la buena gestión, los valores democráticos y el fortalecimiento de la institucionalidad política y de las organizaciones de la sociedad civil. Se prestará atención especial al desarrollo de programas y actividades para la educación de la niñez y la juventud como forma de asegurar la permanencia de los valores democráticos, incluidas la libertad y la justicia social (OEA, 2001).

\subsection{Convención Americana - Pacto de San José. San José, Costa Rica, 22 de noviembre de 1969}

Aprobada por Colombia mediante la Ley 16 de 1972.

La Convención Americana, o "Pacto de San José de Costa Rica", consagra el derecho de los NNA a ser protegido por la familia, la sociedad y el mismo Estado.

La Convención establece como medios de protección dos órganos competentes: A la" Comisión Interamericana de Derechos Humanos (CIDH) y a la Corte Interamericana de Derechos Humanos (CIDH, 1969). 
La “Comisión Interamericana de Derechos Humanos" es un órgano principal de la OEA que se encarga de la protección y promoción de los D.H a nivel mundial. La comisión ha puesto siempre un especial interés en lo relativo a los D.H de los NNA. Por tal razón en su periodo ordinario de sesiones número 100 realizado en Washington D. C. entre el 24 de septiembre y el 13 de octubre de 1998, creo la "Relatoría sobre los Derechos de la Niñez" (CIDH, 1998) que tiene como tarea estudiar y promocionar acciones y actividades que permitan realizar una evaluación sobre la situación de los D.H de los NNA en todos los Estados que hacen parte de la OEA, y proponerle a estos que adecuen sus normas internas para que se hagan efectivos los D.H de los NNA (OEA, 2013).

La Corte Interamericana de Derechos Humanos es la institución judicial de carácter autónomo de la OEA, su fin es aplicar y realizar la correcta interpretación de la "Convención Americana sobre Derechos Humanos" y de los otros tratados que atañen a la misma materia.

En desarrollo de su labor emite opiniones consultivas(interpretación de la Convención Americana, otros tratados y leyes de manera abstracta; esto es, sin un caso en concreto), por la emisión de sentencias contenciosas (interpretación de la Convención Americana y otros tratados que le reconocen competencia a partir de casos concretos en los que se denuncia la violación de derechos humanos), y por medio de resoluciones de medidas provisionales (estrechamente relacionadas con los casos contenciosos: son medidas que se dictan para evitar que se consuma de manera irreparable una violación de derechos humanos) (Corte Interamericana de Derechos Humanos, 2018).

\subsubsection{6. "Convención interamericana para prevenir, sancionar y erradicar la violencia contra la mujer “Convención de Belem Do Para”. Belem Do Pará, Brasil, 1994}

La Convención de Belem Do Pará, en el artículo 7, establece que

En este documento se condena cualquier tipo de violencia que se ejerza sobre la mujer; y se acuerda adoptar de forma urgente y sin dilaciones por parte de los Estados, los mecanismos para prevenir sancionar y eliminar cualquier forma de violencia contra las mismas, estos mecanismos se harán a través de políticas públicas que permitan el logro de este objetivo. Se establece que no dable aceptar que una mujer pueda ser agredida de forma alguna y que las autoridades y sus agentes deben velar cumplan con esta obligación, en caso de presentarse 
algún tipo de violencia hacia la mujer se debe llevar a cabo por parte de los operadores judiciales las labores de prevención, investigación y sanción de las conductas que atenten contra la mujer; de igual manera se acuerda la inclusión dentro del ordenamiento interno de Normas de tipo penal, civil y administrativo o de cualquier otra naturaleza que permitan realizar la protección integral de la mujer. Se debe contar con las medidas jurídicas que eviten que el agresor hostigue, amenace o intimide de manera alguna a la mujer o que ponga en peligro su integridad física o moral. En caso de no existir dentro de la normatividad interna medidas legislativas o existir algunas que permitan el maltrato y la agresión están deben abolirse y establecerse las que permitan la protección de la mujer y su acceso a un proceso justo y eficaz en el cual pueda tener derecho a la reparación y a su derecho de no repetición (OEA, 1994b).

Los firmantes de la convención se comprometieron a proveer la atención necesaria a la mujer víctima de violencia, involucrando tanto al sector oficial como al privado, ya sea estableciendo programas especiales o creando centros de acogida en donde tanto la mujer como la familia cuente con una atención especializada. (OEA, 1994b).

Respecto a la vulnerabilidad de la mujer que se puede dar en razón a su etnia o por ser migrante o refugiada o por ser víctima de desplazamiento los Estados se comprometen a adoptar las medidas necesarias para su protección de la violencia en su contra, dentro de este grupo también se incluyen las mujeres en estado de gestación, o que presenten alguna discapacidad, sea menor de edad o adulta mayor o su situación económica se vea afectada por problemas de conflictos armados interno o de privación de su libertad (OEA, 1994b).

\subsubsection{Esfuerzos jurisprudenciales}

La competencia de la Corte inicia cuando se presenta el caso y esta avoca conocimiento de los hechos, verifica su ocurrencia según se plantee en la demanda, decide si se presenta la violación referida y verifica el vínculo entre los hechos y las violaciones a los derechos humanos alegadas, y ordena que se garanticen los derechos conculcados y de ser el caso que se repare a las víctimas. 
Para hacer el análisis de la jurisprudencia se tomarán aspectos como: a) definición de niño y adolescente, b) medidas de protección a favor de los NNA c) los derechos de los NNA como un “derecho adicional" y e) el interés superior del niño.

\subsection{Respecto a la definición de niño}

En la sentencia del caso "Niños de la calle", la Corte señaló que "el artículo 19 de la Convención Americana no define qué se entiende como "niño" (Corte IDH, 1999, Sentencia Serie C N. 63, párr. 188). No obstante ese tribunal utilizo como definición de niño el referido en el artículo 1 de la "Convención sobre Derechos del Niño que considera como tal "a todo ser humano que no haya cumplido los 18 años, salvo que, en virtud de la ley que le sea aplicable, haya alcanzado antes la mayoría de edad" (Corte Interamericana de Derechos Humanos, 1999)

En esta sentencia la CIDH por primera vez que se había violado el artículo 19 de la Convención Americana (Derechos del Niño), el cual establece que: "todo niño tiene derecho a las medidas de protección que su condición de menor requiere por parte de su familia, de la sociedad y del Estado" (Corte Interamericana de Derechos Humanos, 1999).

Indicó además que ser mayor de edad implica poder ejercer plenamente sus derechos y poseer una capacidad de decidir y actuar característica esta que no está presente en gran medida en los niños lo que no supone que no sean sujetos sometidos a derechos que son inherentes al ser humano, en otra palabra "son sujetos de derechos, titulares de derechos inalienables e inherentes a la persona humana (Corte IDH, 2002, Opinión Consultiva OC-17/02, párr. 41 y 42).

\subsection{Las "medidas de protección" a favor de los NNA}

La Corte Interamericana ha establecido que los articulo19 de la convención y el 17 de la misma están estrechamente relacionados ya que reconoce a la familia como la base fundamental de la sociedad; y que por lo tanto debe ser objeto de protección tanto del Estado como de la misma sociedad. De igual manera reconoce el derecho a la privacidad que tiene el entorno familiar y que está consagrados en el artículo 11.2 de la convención que prohíbe las "injerencias arbitrarias o abusivas en la familia" (Corte IDH, 2010, Sentencia del 25 de mayo, párr. 157).

La corte al referirse a las medidas de protección a los NNA cita el caso colombiano de "las masacres de Ituango" perpetradas por grupos paramilitares en los corregimientos de La Granja y El 
Aro en el municipio de Ituango (Antioquia). Respecto a esto, la Corte se refirió en sentencia del 1 de julio de 2006 diciendo que existe: "Una responsabilidad agravada del Estado cuando se configuran dichas injerencias cuyas víctimas son niños, niñas y adolescentes, teniendo en cuenta 'su condición de vulnerabilidad, en razón de su edad" (Corte interamericana de Derechos Humanos, 2006, Sentencia del 1 de julio, párr. 244-246).

\subsection{Los derechos de los NNA tomados como derecho adicional}

Jurisprudencialmente la Corte ha ratificado que los NNA, son sujetos de derecho dentro de los Derechos Humanos en las mismas condiciones que los adultos es decir no existe distinción en razón a su edad, pero si tienen derechos adicionales especiales por su condición de NNA (Corte IDH, 2002, Opinión Consultiva OC-17/02, párr. 54); (Corte IDH, 2004, Sentencia del 2 de septiembre, párr. 147).

Según la Corte es el artículo 19 de la Convención Americana quien explica lo que debe ser tomado como derecho adicional y complementario, dirigido a quienes por no haber alcanzado física y emocionalmente su desarrollo completo deben contar con una protección especial (Corte IDH, 2002, Opinión Consultiva OC-17/02, párr. 53, 54 y 60); (Corte IDH, 2004, Sentencia del 2 de septiembre, párr. 147); (Corte IDH, 2009, Sentencia del 24 de noviembre, párr. 184); (Corte IDH, 2010, Sentencia del 25 de mayo, párr. 164).

\subsubsection{4. "Interés superior del niño"}

En la sentencia del caso González y otras (“Campo algodonero"), dijo la Corte que

La prevalencia del interés superior del niño debe ser entendida como la necesidad de satisfacción de todos los derechos de la infancia y la adolescencia, que obliga al Estado e irradia efectos en la interpretación de todos los demás derechos de la Convención cuando el caso se refiera a menores de edad (Corte IDH, 2009, Sentencia del 16 de noviembre, párr. 408). (Ibañez, Juana .s,f))

Las sentencias de la Corte IDH han permitido que se haya investigado los hechos presentados y se haya podido identificar y sancionar a quienes fueron autores de los mismos, y que se adopten 
en los Estados disposiciones internas que aseguren el cumplimiento de las decisiones adoptadas por la Corte.

\subsection{Conclusión estándares Sistema Interamericano}

Como puede observarse, en Latinoamérica la problemática del ASI es una realidad que los Estados han tratado de manejar a través de la incorporación de los instrumentos internacionales como la Convención de los Derechos del Niño y sus diferentes protocolos.

Se puede colegir entonces que los países latinoamericanos y la OEA han realizado esfuerzos grandes en la prevención y protección a los NNA de la violencia sexual con el reforzamiento de algunas políticas en materia de legislación que permitan tratar de disminuir la problemática.

\subsubsection{Estándares nacionales}

\subsubsection{Constitución Política (1991)}

El artículo 1 establece como uno de los principios fundamentales el respeto a la dignidad humana y establece que

Los niños, niñas y adolescentes deberán ser protegidos de cualquier situación que afecte su desarrollo físico social moral educativo, así que no pueden estar en estado de abandono ni ser objeto de violencia física o moral, no pueden ser secuestrados, explotados laboral, o económicamente, y deben ser protegidos especialmente contra la explotación sexual, su venta y comercialización con fines sexuales o de cualquier otro tipo que implique riesgo para su integridad y que "gozarán también de los demás derechos consagrados en la Constitución, en las leyes y en los tratados internacionales ratificados por Colombia (Const., 1991, art. 1).

El artículo 44 igualmente preceptúa que

Son derechos fundamentales de los niños: la vida, la integridad física, la salud y la seguridad social, la alimentación equilibrada, su nombre y nacionalidad, tener una familia y no ser separados de ella, el cuidado y amor, la educación y la cultura, la recreación y la libre expresión de su opinión (Congreso de la republica de Colombia, 1991, art. 44). 
Estos derechos consagrados en la Constitución nacional tienen rango constitucional, lo que significa que no pueden ser derogados por norma inferior a esta, que los contiene y según los procedimientos establecidos para reformar la Carta.

Tener un rango constitucional significa que, por encima de todo el ordenamiento jurídico de un país, está la Constitución Política del mismo que se considera como la máxima ley del Estado y fundamenta el resto del ordenamiento interno, y ninguna ley la puede derogar o cambiar.

Igualmente, el artículo 93 establece que

Los tratados y convenios internacionales ratificados por el Congreso, que reconocen los derechos humanos y que prohíben su limitación en los estados de excepción, prevalecen en el orden interno. Los derechos y deberes consagrados en esta Carta se interpretarán de conformidad con los tratados internacionales sobre derechos humanos ratificados por Colombia. El Estado colombiano puede reconocer la jurisdicción de la Corte Penal Internacional en los términos previstos en el Estatuto de Roma, adoptado el 17 de julio de 1998 por la Conferencia de Plenipotenciarios de las Naciones Unidas y, consecuentemente, ratificar este tratado de conformidad con el procedimiento establecido en esta Constitución. La admisión de un tratamiento diferente en materias sustanciales por parte del Estatuto de Roma con respecto a las garantías contenidas en la Constitución tendrá efectos exclusivamente dentro del ámbito de la materia regulada en él (Congreso de la Republica de Colombia, 1991.Const. art. 93).

\subsubsection{Ley orgánica de la defensa del niño}

(Congreso de la República de Colombia, 1946, Ley 83)

En esta ley se trató por primera vez el tema de la protección de los menores con limitaciones. Estableció la jurisdicción para los NNA. Definió, que son los estados de peligro tanto físico como moral, y las correspondientes medidas para la protección de los NNA y creo el" Consejo Nacional de Protección" (Congreso de la Republica de Colombia, 1947).

Esta ley representó los primeros esfuerzos del Estado colombiano por proporcionar una protección a los menores de 18 años; por tanto, se puede considerar que inició el camino para llegar hasta el momento actual cuando ya se cuenta con una protección de los NNA, acorde con lo preceptuado en el artículo 19 de la Convención del Niño. 
El artículo 1 establecía que el menor de 18 años, hombre o mujer, que se encuentre abandonado o en peligro físico o moral debería ser objeto de asistencia y protección.

De igual manera, el artículo 6 indicaba que los menores deberían tener la asistencia de un médico psiquiatra, quien debería evaluar a los NNA enviados por la justicia, realizándoles exámenes médicos generales y psiquiátricos, y determinar el procedimiento para mantener la salud en todos sus aspectos a los mismos, recomendar su envió a centros de salud o de protección y la separación del entorno familiar si se requería según el caso.

\subsubsection{Ley 75 de 1968}

Esta ley crea el "Instituto Colombiano de Bienestar Familiar (ICBF)". Esta norma se encuentra aún vigente y representa la voluntad del Estado por crear una entidad con énfasis en los NNA; crea entonces el ICBF con carácter de establecimiento público con personería jurídica, autónoma administrativamente y un patrimonio propio.

El ICBF es la entidad que trabaja por la prevención y protección integral de la primera infancia, la niñez, la adolescencia y el bienestar de las familias en Colombia, brindando atención especialmente a aquellos en condiciones de amenaza, inobservancia o vulneración de sus derechos, llegando a más de 8 millones de colombianos con sus programas, estrategias y servicios de atención, con 33 sedes regionales y 211 centros zonales en todo el país (ICBF, s.f.).

\subsubsection{Ley 7 de 1979}

Se encuentra aún vigente; crea el "Sistema Nacional de Bienestar Familiar" (Congreso de la República de Colombia, 1979, Ley 7). Preceptúa que el bienestar de la familia se considera un servicio público del cual es responsable el Estado y que se prestara a través del "Sistema Nacional de Bienestar Familiar conforme lo establece esta ley por medio de entidades tanto del gobierno como privadas debidamente autorizadas.

Según el PNDU, en la publicación Abecé del Sistema Nacional de Bienestar familiar (2014):

El Sistema Nacional de Bienestar Familiar es el conjunto de agentes, instancias de coordinación y articulación y de relaciones existentes entre estos para dar cumplimiento a la 
protección integral de los NNA y el fortalecimiento familiar en los ámbitos nacional, departamental, distrital y municipal (PNUD, 2014).

En la Ley 7 también se establecen (en los artículos 3 al 7) los derechos de los niños tales como:

Ser parte en los programas estatales y acceder a la formación básica, recibir por parte del Estado asistencia especial, tener un buen nombre y una nacionalidad, tener acceso a la educación, al bienestar social, a la salud, la recreación y el deporte, a vivir en familia, a los cuidados y tratamientos necesarios hasta logar su recuperación en caso de enfermedad, y en caso de desastres ser de los primeros en recibir asistencia. (Congreso de la República de Colombia, 1979, Ley 7).

\subsubsection{Código del Menor}

(Presidencia de la República de Colombia, 1989, Decreto 2737).

Su Importancia radicó en que garantizaba a los NNA que estuvieran en el país, ejercer y disfrutar de forma efectiva de todos los derechos fundamentales preceptuados. Así mismo, definió y estableció las medidas para dar la debida protección a los NNA, y la forma de relacionarse el Estado, la familia y la sociedad con los NNA desde el momento de nacer hasta adquirir la mayoría de edad.

Su objetivo fue:

Consagrar los derechos fundamentales del menor, determinar los principios rectores que orientan las normas de protección al menor, tanto para prevenir situaciones irregulares como para corregirlas, definir las situaciones irregulares con las cuales pueda encontrarse el menor; origen, características y consecuencias de cada una de tales situaciones, determinar las medidas que deben adoptarse con el fin de proteger al menor que se encuentre en situación irregular. señalar la competencia y los procedimientos para garantizar los derechos del menor, establecer y reestructurar los servicios encargados de proteger al menor que se encuentre en situación irregular, sin perjuicio de las normas orgánicas y de funcionamiento que regulan el Sistema Nacional de Bienestar familiar (Congreso de la republica de Colombia, Decreto2737, 1989). 
El artículo 8 establecía el derecho del menor a no ser abandonado, no sufrir ningún tipo de violencia, a ser cuidado y tratado con respeto, a no ser objeto de violencia sexual o cualquier tipo de explotación; consagro que el Estado debería garantizar su protección integral.

A pesar de que el Código del Menor consagraba principios para la protección de los NNA solamente contemplaba situaciones irregulares que enfrentaban algunos NNA y no brindaba una protección integral al resto, con base en esta falencia fue necesario instituir la "Ley de Infancia y Adolescencia".

\subsubsection{Ley 679 de 2001}

El objeto de esta ley es dictar "medidas de protección contra la explotación, la pornografía, el turismo sexual y demás formas de abuso sexual con menores de edad. Establece normas de carácter preventivo y sancionatorio, y otras disposiciones en desarrollo del artículo 44 de la Constitución de 1991” (Congreso de la republica de Colombia, 2001).

Su importancia radica en que por primera vez en la normatividad colombiana se avoca la protección de los niños en asuntos sexuales; su aplicación está sujeta a todo tipo de personas (naturales y jurídicas) cuyo domicilio este en Colombia, y a regirse de acuerdo al artículo 62 de la Ley 300 de 1996 respecto del turismo nacional o internacional.

Se incluye en esta ley la reglamentación sobre redes globales y su uso en el que se vean involucrados menores; y se establece la prohibición a los proveedores y servidores de alojar material de algún tipo en el que aparezcan actividades sexuales que involucren menores de edad.

Artículo 7. Prohibiciones. Los proveedores o servidores, administradores y usuarios de redes globales de información no podrán:

1. Alojar en su propio sitio imágenes, textos, documentos o archivos audiovisuales que impliquen directa o indirectamente actividades sexuales con menores de edad.

2. Alojar en su propio sitio material pornográfico, en especial en modo de imágenes o videos, cuando existan indicios de que las personas fotografiadas o filmadas son menores de edad.

3. Alojar en su propio sitio vínculos o links, sobre sitios telemáticos que contengan o distribuyan material pornográfico relativo a menores de edad (Congreso de la Republica de Colombia, 2001, Ley 679, 2001). 
La ley también creo un fondo para luchar contra la contra la explotación sexual de los NNA cuyo objeto es la financiación de programas para la prevención y la lucha contra esta problemática para esto el gobierno colombiano creo una cuenta especial que hace parte del ICBF (Congreso de la República de Colombia, 2001, Ley 679).

\subsubsection{Ley 1098 de 2006}

Llamada "Código de la Infancia y la Adolescencia".

Tiene por finalidad garantizar a los NNA un desarrollo adecuado dentro de una familia y un entorno social adecuado, en donde reciban amor comprensión y puedan ser felices; velar por que los derechos estipulados en convenciones, tratados, protocolos, normas internas y constitucionales se cumplan a cabalidad; para este fin instituye leyes sustantivas y procesales para la protección de los NNA (Congreso de la Republica de Colombia, Ley 1098 de 2006)

Está encaminada a todos los NNA hasta adquirir su mayoría de edad y a los que habiendo llegado a esta tengan alguna protección especial por parte del Estado; todos cobijados con los principios universales de igualdad, dignidad, solidaridad, equidad y justicia social; sus enfoques buscan garantizar a los NNA, su desarrollo pleno y armonioso, en un ambiente sano y de convivencia (Congreso de la Republica de Colombia, Ley 1098, 2006).

La naturaleza de las normas contenidas en este Código es de orden público, de carácter irrenunciable y los principios y las reglas en ellas consagradas se aplicarán de preferencia a las disposiciones contenidas en otras leyes (Congreso de la Republica de Colombia, Ley 1098, 2006).

Establece la protección integral como:

El reconocimiento de los niños, niñas y adolescentes como sujetos de derechos, la garantía y cumplimiento de estos, la prevención de su amenaza o vulneración y la seguridad de su restablecimiento inmediato, en desarrollo del principio del interés superior del niño (Congreso de la Republica de Colombia, Ley 1098, 2006).

El Estado colombiano ha materializado este propósito mediante la implementación y creación de políticas públicas, programas y otra serie de acciones que se realizan a nivel nacional, 
departamental distrital y municipal y municipal asignando los recursos necesarios tanto de tipo económico como humanos.

La Ley de Infancia y Adolescencia no solo permite la protección de los NNA, sino que también trae la parte sancionatorio en caso de los NNA ser infractores de la normatividad colombiana.

La ley mencionada elimina cualquier tipo de beneficio penal para los abusadores de NNA; no se aplicarán rebajas de penas por sentencia anticipada o confesión, ni se permitirá la casa por cárcel para los abusadores; de igual manera y consecuentemente endurece las penas para este tipo de delitos y reconoce que la niñez y la juventud son de vital importancia en cualquier sociedad.

El artículo 9 establece "la prevalencia de los derechos de los NNA" que ha sido la base para importantes decisiones judiciales:

Dice esta norma que los derechos de los NNA prevalecerán sobre cualquier otro derecho que tengan las personas en decisiones judiciales, administrativas o cualquier otra que se adopte relacionadas con ellos y en caso de conflictos por esta razón prevalecerán los de los NNA

En caso de conflicto entre dos o más disposiciones legales, administrativas o disciplinarias, se aplicará la norma más favorable al interés superior del niño, niña o adolescente (Congreso de la Republica de Colombia, Ley 1098, 2006 ).

El artículo 11, dispone que cualquier persona puede exigir que los derechos de los NNA sean restablecidos, pero teniendo en cuenta lo que disponga la ley respecto a la legitimidad en la causa para presentar las correspondientes acciones judiciales o los procedimientos de tipo administrativo en favor de los NNA (Congreso de la República de Colombia, 2006, Ley 1098).

Se puede afirmar entonces que esta Ley conforme a la normatividad colombiana nos permite definir principios como el interés superior, la igualdad social y de género, la prevalencia de los derechos de los NNA, las corresponsabilidades que deben tener el Estado, la familia y la sociedad para ser garantes de los derechos de los NNA y la exigibilidad de estos frente a decisiones de tipo administrativo o judicial en los cuales estén involucrados.

Esta ley igualmente trata lo relativo a políticas públicas, tema que será tratado más adelante en este estudio. 


\subsubsection{Ley 1146 de 2007}

Contiene la normatividad para prevenir el ASI y dar la atención integral de los NNA abusados sexualmente. Esta norma permitió que se fortalecieran los espacios intersectoriales y se preste una atención integral a las víctimas de abuso sexual

Creo los “Comités Interinstitucionales Consultivos para la Prevención de la Violencia Sexual y Atención Integral de los NNA", víctimas de la violencia sexual, en todo el territorio nacional (Congreso de la Republica de Colombia, Ley 1146, 2007).

estableció que

Los entes territoriales tanto departamentales, como distritales y municipales, se constituirán bajo la coordinación de las Secretarías de Salud y el Instituto Colombiano de Bienestar Familiar a través de sus Regionales, Comités Interinstitucionales Consultivos para la Prevención de la Violencia Sexual y Atención Integral de los Niños, Niñas y Adolescentes Víctimas del abuso Sexual, según sea su competencia ( Ley 1146 Congreso de la republica de Colombia, 2007, art 4).

Establece que del Comité harán parte, el Ministerio Publico, una Comisaría de Familia, el Juez de Familia del lugar y, en su defecto, el Juez Municipal o el Juez Promiscuo Municipal; y que se rendirán informes semestrales y se incluirán las propuestas de programas y políticas al Subcomité de Infancia y Familia del Consejo de Política Social (Congreso de la Republica de Colombia, Ley 1146, 2007, art, 4).

\subsubsection{Decreto 936 de 2013}

Reorganiza el "Sistema Nacional de Bienestar Familiar", a cargo del ICBF y lo articula con las entidades que tienen la responsabilidad de garantizar los derechos de los NNA, de prevenir que estos sean vulnerados y dar la protección necesaria hasta la restitución de los mismos (Presidencia de la Republica de Colombia, Decreto 936, 2013).

\subsubsection{Decreto 87 de 2017}

Reglamento el funcionamiento del "Fondo contra la Explotación Sexual de Niños, Niñas y Adolescentes", se creó según el artículo 24 de la Ley 679 de 2001, la cual fue adicionada y 
robustecida por la Ley 1336 de 2009, con el objeto de proveer rentas destinadas a la inversión social, garantizar la financiación de los planes y programas de protección integral, y restablecer los derechos de los NNA víctimas de explotación sexual (Presidencia de la Republica de Colombia, Decreto 87 de 2017, 2017).

Establece con base en algunos artículos de la Ley 679 de 2001 que son recursos para el fondo los siguientes:

Las partidas que se le asignen en el presupuesto nacional, los recursos provenientes de crédito interno y externo, las donaciones que reciba, los recursos de cooperación nacional o internacional, los bienes, rendimientos y frutos que generen los inmuebles que hayan sido utilizados para la comisión de actividades de utilización sexual de niños, niñas y adolescentes, y cuya extinción dominio se haya decretado, así como los recaudos generados en virtud la destinación provisional de tales bienes, los recursos provenientes del recaudo del impuesto sobre el alquiler de películas de clasificación X para adultos, los recursos provenientes del impuesto de salida de extranjeros del territorio colombiano, los recursos provenientes de las multas impuestas por el Ministerio de Tecnologías de la Información Comunicaciones, con ocasión de las sanciones administrativas a proveedores o servidores, administradores y usuarios responsables, que operen en el territorio colombiano, por incumplimiento a lo consagrado en artículo 10 la Ley 679 de 2001, y los demás que obtenga a cualquier título (Presidencia de la Republica de Colombia, Decreto 87, 2017).

Tabla 4.

Normas colombianas vigentes para la protección de los NNA

\begin{tabular}{|l|l|}
\hline NORMA & ASPECTO QUE REGULA \\
\hline Ley 906 de 2004 & $\begin{array}{l}\text { Código de Procedimiento Penal. Artículos 205, 206, 207, 208, } \\
209,210,210,213,231,214,217,217,218,219,219,219,188 \\
\text { y } 188 .\end{array}$ \\
\hline Ley 1098 de 2006 & $\begin{array}{l}\text { Consagra la protección integral de NNA con el objeto de } \\
\text { garantizar los derechos y libertades estipuladas en los tratados } \\
\text { Internacionales. }\end{array}$ \\
\hline
\end{tabular}




\begin{tabular}{|c|c|}
\hline Ley 1146 de 2007 & $\begin{array}{l}\text { Contiene normas para prevenir el ASI y brindar la atención } \\
\text { integral de los NNA abusados sexualmente. }\end{array}$ \\
\hline Ley 975 de 2005 & de las víctimas en procesos de paz. \\
\hline Ley 1236 de 2008 & $\begin{array}{l}\text { Modifica algunos artículos del Código Penal en cuanto a los } \\
\text { delitos de abuso sexual. }\end{array}$ \\
\hline Ley 1257 de 2008 & $\begin{array}{l}\text { Contiene normas para sensibilizar, prevenir y sancionar formas } \\
\text { de violencia y discriminación contra la mujer, reforma los C.P. } \\
\text { C.P.P y la Ley } 294 \text { de } 1996\end{array}$ \\
\hline Ley 1329 de 2009 & $\begin{array}{l}\text { Modifica el Título IV de la Ley } 599 \text { de } 2000 \text { y se imponen otras } \\
\text { disposiciones para la lucha contra la explotación sexual y } \\
\text { comercialización de NNA. }\end{array}$ \\
\hline Ley 1336 de 2009 & Adiciona y fortalece la Ley 679 de 2001 \\
\hline Ley 1453 de 2011 & Reforma el C.P, el C.P.P y el Código de Infancia y Adolescencia. \\
\hline Ley 1652 de 2013 & $\begin{array}{l}\text { Regula la entrevista y el testimonio en procesos penales de NNA } \\
\text { víctimas de delitos contra la libertad, integridad y formación } \\
\text { sexuales. }\end{array}$ \\
\hline Ley 1714 de 2014 & $\begin{array}{l}\text { Adopta medidas que garanticen que las víctimas de ASI tengan } \\
\text { acceso a la Justicia. }\end{array}$ \\
\hline Ley 1709 de 2014 & $\begin{array}{l}\text { Enfoque diferencial de penas y medidas de aseguramiento, } \\
\text { competencia de jueces, penas y medidas de aseguramiento. }\end{array}$ \\
\hline Ley 765 de 2002 & $\begin{array}{l}\text { Aprueba el "Protocolo Facultativo de la Convención sobre los } \\
\text { Derechos del Niño" en cuanto a la comercialización y venta de } \\
\text { NNA, la prostitución infantil y su utilización en pornografía. }\end{array}$ \\
\hline Ley 679 de 2001 & $\begin{array}{l}\text { Expide estatuto para prevenir y evitar que los NNA sean } \\
\text { explotados y usados en la pornografía y el turismo sexual. }\end{array}$ \\
\hline Decreto 2968 de 2010 & $\begin{array}{l}\text { Crea la "Comisión Intersectorial para la promoción y garantía de } \\
\text { los derechos sexuales y reproductivos". }\end{array}$ \\
\hline $\begin{array}{l}\text { Resolución } 459 \text { de } \\
2012 \text { del Ministerio de } \\
\text { Salud }\end{array}$ & $\begin{array}{l}\text { Aprueba el "Protocolo de atención integral en salud para víctimas } \\
\text { de violencia sexual". }\end{array}$ \\
\hline
\end{tabular}




\begin{tabular}{|l|l|}
\hline $\begin{array}{l}\text { Resolución 6022 de } \\
2010\end{array}$ & $\begin{array}{l}\text { Aprueba los lineamientos técnicos del "programa especializado } \\
\text { de atención" a NNA, víctimas de violencia sexual a los que no se } \\
\text { les han respetado sus derechos. }\end{array}$ \\
\hline
\end{tabular}

Fuente: Instituto de Bienestar Familiar (ICBF). (ICBF, 2016)

\subsubsection{Jurisprudencia de las diferentes Cortes colombianas para la protección de los derechos de los NNA}

El Estado colombiano consciente de la problemática que representa el ASI en el país ha hecho ingentes esfuerzos por sumarse a la lucha mundial contra este flagelo; por esta razón se encuentra en el Código Penal vigente en Colombia los "delitos contra la libertad, integridad y formación sexuales tipificados en el Libro II, Título IV (Congreso de la Republica de Colombia, Codigo Penal, 2000).

Pero no solo el Estado se ha preocupado por expedir normatividad relativa a la protección de los NNA, sino que las mismas Cortes han legislado al respecto; un ejemplo claro es la sentencia de la Corte (2008), en la que prohíben tener relaciones con menores de 14 años.

Para el análisis de la jurisprudencia se tendrá en cuenta aspectos como: a) violencia sexual infantil, b) capacidad para el ejercicio de la sexualidad referida a los NNA, c) valor del testimonio de los NNA frente a los procesos de violencia sexual, d) derecho de los NNA a no sufrir violencia sexual, e) la prevención y protección contra el abuso sexual, y f) el interés superior del niño.

\subsubsection{Abuso sexual contra los NNA}

Las Cortes colombianas se han preocupado por recalcar lo concerniente a la protección especial a quienes no hayan cumplido 14 años y por eso enfatizan la importancia de la medida diferenciada o protección reforzada. Además, frente al ASI recogen en diferentes sentencias los postulados de la “Convención de los Derechos del Niño" y su derecho a no ser objeto de ninguna forma de violencia, entendiéndose el ASI como una forma de violencia. Así lo ha dicho la Corte a este respecto:

La medida diferenciada sin duda persigue un fin constitucional por cuanto el artículo 44 constitucional señala a los menores no solo como sujetos de especial protección sino además sujetos de una protección reforzada. Así pues, evitar que sobre menores de 14 años se ejerzan 
actos abusivos de tipo sexual cumple fielmente con los propósitos señalados por la Constitución para los niños, en este caso los menores de 14 años (Corte Constitucional, Sentencia C- 876, 2011).

La Ley penal ha incrementado las penas a "quien vulnere o violente los derechos sexuales o reproductivos de los menores mayores de 14 años" (Corte Constitucional, Sentencia C- 876, 2011).

Así mismo, las Cortes han reiterado el compromiso que tiene Colombia con los tratados internacionales. Así se han expresado al respecto:

A partir del artículo 44 de la Carta, en concordancia con los artículos 19-1, 34, 35 y 36 de la Convención sobre los Derechos del Niño, es posible afirmar la existencia en nuestro ordenamiento del derecho de los niños, niñas y adolescentes a no ser objeto de ninguna forma de violencia, especialmente de violencia sexual (Corte Constitucional, Sentencia T-843, 2011).

El reconocimiento de este derecho se fundamenta además en la importancia que un entorno de crianza respetuoso y exento de violencia tiene para la realización de la personalidad de los niños y para el fomento de ciudadanos sociales y responsables que participen activamente en la comunidad local y en la sociedad en general (Corte Constitucional, Sentencia T-843, 2011).

\subsubsection{Capacidad para el ejercicio de la sexualidad referida a los NNA}

A pesar de que ningún instrumento internacional ha establecido una edad en la pueda considerarse que se pueden tener relaciones sexuales, en muchos países se ha fijado una atendiendo a razones como la inmadurez del niño para comprender el acto sexual, lo que puede ocasionar daños en su sexualidad.

En Colombia se ha fijado la edad de consentimiento en los 14 años, aun cuando es claro que la protección del artículo 34 de la CDN en contra de la explotación sexual de los menores de edad se extiende hasta los 18 años, con independencia de que exista una "edad de consentimiento sexual inferior" (Hodgkin y Newell, 2007) (Gonzalez, 2016). 
La Corte al referirse a la edad de consentimiento ha expresado

Las personas menores de 14 años no se encuentran en condiciones de asumir sin consecuencias para el desarrollo de su personalidad el acto sexual, debido al estadio de madurez que presentan sus esferas intelectiva, afectiva y volitiva. Los actos sexuales cometidos sobre ese grupo afectan el desarrollo de su personalidad y pueden producir alteraciones importantes que incidan luego en su vida y equilibrio futuro (Corte Suprema de Justicia, Sala de Casacion Penal, Sentencia 13466, 2000).

Según lo anterior, en Colombia se considera que una persona tiene la suficiente capacidad para entender el acto sexual sin que sufra menoscabo de su posterior vida sexual a los 14 años; no obstante, no es claro por qué razón se considera esta edad como la apropiada, pues es una realidad que actualmente y gracias a la tecnología y los medios de comunicación, los NNA entran en contacto con su sexualidad de forma directa a menos edad que antes, razón por la cual la posibilidad de una sexualidad temprana es mayor. Por otro lado, tampoco es tan cierto que, al llegar a esa edad, mágicamente se adquiera la capacidad de entender con plenitud lo que implica la sexualidad responsable, sino que este es un proceso que incluye una formación para su cabal comprensión.

\subsubsection{Valor del testimonio de los NNA frente a los procesos de violencia sexual}

Cuando un menor hace parte de un proceso penal se debe tener en cuenta que esta debe ser efectiva realmente y no meramente de figuración, teniendo cuidado en que la información que se les proporcione pueda ser comprendida de acuerdo con su edad y su nivel de educación; de igual manera, las entrevistas que se les haga deben estar acordes con lo previsto en el C.I.A.

Según lo anterior, en las primeras etapas de indagación e investigación quien debe actuar será el defensor de familia, quien interrogará al niño(a) con el cuestionario que remita el juez o el fiscal.

La Ley 1652 de 2013 establece para este procedimiento que, si la entrevista forense es realizada por el CTI a los NNA víctimas, el cuestionario de preguntas debe ser revisado anteriormente por el defensor de familia.

La Corte Constitucional, mediante sentencia T-117 del 7 de marzo de 20132, expuso que "La entrevista forense debe ser tomada por expertos en psicología o cualquier otra ciencia del 
comportamiento humano, en un ambiente de confianza que influye en la declaración libre del menor (Corte Constitucional de Colombia, Sentencia T -117/13, 2013).

Según la Jurisprudencia los testimonios de las víctimas den ASI son de gran valor en el proceso penal. En este sentido, la Corte Suprema de Justicia sostuvo que: "A partir de investigaciones científicas es posible concluir que el dicho del menor, por la naturaleza del acto y el impacto que genera en su memoria, adquiere gran credibilidad cuando es la víctima de abusos sexuales" (Corte Suprema de Justicia Colombia, Sentencia 23706, 2006).

En Colombia la "Constitución Política elevó al niño a la posición de sujeto merecedor de especial protección por parte del Estado, la sociedad y la familia (artículos 44 y 45) (Congreso de la Republica de Colombia, Constitucion Politica, 1991).

Con base en esto es claro que el testimonio de la victima de ASI tiene valor probatorio y por tanto debe ser valorada y tenida en cuenta por el operador judicial al momento de hacer su análisis del caso. No le corresponde al menor agredido demostrar la ocurrencia del hecho sino al Estado (Corte Suprema de Justicia, 2006, Proceso 23706).

La doctrina actualizada contenida en los fallos de la Corte Suprema de Justicia y de la Corte Constitucional, coincide con los resultados de investigaciones científicas según las cuales, la mayoría de los niños poseen la capacidad moral y cognitiva de dar su testimonio en los tribunales y su dicho deber ser analizado junto con los demás medios de convicción allegados a un proceso, particularmente en los casos de abusos sexuales, en los cuales, ante los intentos de disminuir la revictimización del niño, se acude a psicólogos especialistas que ayuden al menor a expresar lo sucedido (Corte Constitucional de Colombia, Sentencia T- 078, 2010) .

\subsubsection{Testimonio del menor}

EL "Código de la Infancia y la Adolescencia" traza el derrotero que debe seguir un proceso judicial que incluya como víctimas a los NNA para así garantizarles la debida protección y garantizar el cumplimiento de todos sus derechos. 
Se debe tener cuidado cuando se decrete y realice la prueba testimonial por parte de los NNA para no revictimizarlos y se debe estudiar por parte del operador judicial la pertinencia, utilidad y conducencia del testimonio de los NNA, sin perder de vista que también es un derecho de la víctima a ser escuchado y a ser tenida en cuenta su aseveración respecto a los hechos.

Actualmente es discrecionalidad del juez si decreta o no el testimonio del NNA si decreta o no la práctica del testimonio del NNA cuando esta es solicitada por la fiscalía o una de las partes en la acusación y audiencia preparatoria.

Con base en lo expuesto por las diferentes sentencias es claro que el testimonio del menor debe ser parte importante dentro de los procesos judiciales que los involucren por ser víctimas de abusadores, teniendo especial cuidado en no revictimizar a los NNA objeto del ASI, razón por la cual es necesario que todos los operadores judiciales apliquen estos criterios en el momento de la realización de los procesos.

\subsubsection{El derecho de los niños a no ser objeto Abuso sexual}

En Colombia las Cortes han reiterado lo dicho por el CDN, en cuanto a no ser objeto de ninguna forma de violencia, especialmente de violencia sexual.

Así, la Corte Constitucional dice que:

Con base en el artículo 44 de la Constitución Nacional y en concordancia con los artículos 19-1, 34, 35 y 36 de la Convención sobre los Derechos del Niño, es posible afirmar que existe en nuestro ordenamiento, el derecho de los niños, niñas y adolescentes a no ser objeto de ninguna forma de violencia, especialmente de violencia sexual (Corte Constitucional, Sentencia T-843, 2011).

Bajo ningún concepto se debe permitir que los niños sigan siendo objeto de violencia sexual, ni que sus derechos sigan siendo menoscabados; esto en concordancia con lo preceptuado en las diferentes sentencias de las Cortes colombianas.

\subsubsection{La prevención y protección contra el abuso sexual}

Según el artículo 19 de la CDN, Los Estados parte están obligados a establecer medidas, mecanismos y programas para la prevención del ASI a los NNA. 
Los objetivos principales de los programas de prevención del abuso deben ir orientados a evitarlo y detectarlo en una etapa temprana; en este aspecto Colombia ha implementado a través del Ministerio de Educación programas para la educación sexual en las aulas escolares.

La Corte Constitucional ha afirmado, en diferentes sentencias que la educación se constituye en el principal elemento en la lucha contra el abuso sexual, cumple una función preventiva y permite que los NNA se formen y desarrollen valores que les aseguren entender a la sociedad y no ser víctimas de los depredadores sexuales, quienes se valen de la ignorancia para acceder a ellos.

De esta forma la Ley 1146 de 2007 cumple con la función de reforzar al sistema educativo colombiano y por esta razón se requiere que todas las instituciones educativas tengan dentro de su formación académica, una catedra de educación sexual, que inicialmente se pensó para estudiantes de decimo y once grado por poseer un grado de comprensión y desarrollo mayor y ser este grupo de alto riesgo en cuanto a actividad sexual se refiere, pero que debe ser extensiva a todos los niveles guardando las debidas proporciones de edad y desarrollo.

Una de las maneras de prevenir el ASI en los NNA es mediante la educación y la implementación de campañas tendientes a visibilizar los medios de que se valen los agresores sexuales. La Corte Constitucional ha defendido la implementación de la cátedra de sexualidad en los colegios, no obstante, en algunas instituciones esta cátedra se dicta más desde un punto de vista religioso, lo que desvirtúa lo preceptuado por las Cortes.

\subsubsection{El interés superior del niño}

Las cortes colombianas se han pronunciado respecto al tema de la protección especial hacia los NNA y el carácter de supremacía en el interés de los mismos.

Ha dicho la Corte Constitucional que:

Aunque el interés superior del menor alude a la protección integral y simultánea del desarrollo integral y la calidad de vida del menor, analizado desde el punto de vista de su situación particular y concreta, esta Corporación se ha encargado de definir los criterios 
jurídicos que han de guiar la labor de las autoridades judiciales y administrativas en la protección eficaz de dichas garantías, a través del reconocimiento e identificación del interés superior del menor en casos puntuales (Corte Constitucional Republica de Colombia, Sentencia T- 973, 2011).

Dichos criterios son, entre otros, los siguientes: la garantía del desarrollo integral del menor, la garantía del pleno ejercicio de sus derechos fundamentales, la protección del menor frente a riesgos prohibidos, la necesidad de evitar cambios desfavorables en las condiciones presentes del menor involucrado y la necesidad de tomar en cuenta las opiniones expresadas por el menor respecto del asunto que se decide (Corte Constitucional Republica de Colombia, Sentencia T- 973, 2011).

En suma, el interés superior del menor es un principio rector, ampliamente reconocido por el derecho internacional y reproducido de manera directa en la Constitución Política, que propende por la máxima satisfacción de los derechos de que son titulares todos los niños, niñas y adolescentes, entendidos como fundamentales, prevalentes e interdependientes (Corte Constitucional Republica de Colombia, Sentencia T- 973, 2011).

\subsubsection{Conclusiones}

Aunque la violencia sexual de menores sigue siendo una problemática mundial que no ha podido ser erradicada, la implementación de estándares internacionales para luchar contra esta representa el esfuerzo del mundo por proteger a sus NNA de este flagelo.

La CDN, adoptada por las ONU en 1989, es quizá la que mejor responde a la solución de esta problemática pues cuenta con artículos que establecen los derechos de los NNA, y señala como se deben interpretar las normas que contiene; para lograr una integral protección a estos, que sean objeto de ASI.

Los estándares internacionales constituyen una nueva visión de los NNA, pues al reconocérseles sus derechos y dárseles protección especial se incrementa la posibilidad de ser escuchados y su testimonio tener valor probatorio en procesos de cualquier tipo de los que hagan parte y donde ya la potestad del juez no será discrecional.

En la actualidad un número significativo de Estados ha ratificado los tratados y aceptado los protocolos que dan la protección a los NNA, del ASÍ a su normatividad interna tanto a nivel 
latinoamericano, como en Europa, sin embargo, aún subsiste en algunos países alguna reticencia a aceptar plenamente estos mecanismos internacionales y su reconocimiento ha sido de forma gradual, aceptando algunas normas y otras no.

Colombia ha venido implementando leyes, decretos y algunas políticas públicas se ha venido ocupando de la problemática del ASI; de igual manera, las altas Cortes han hecho otro tanto a través de la jurisprudencia y el análisis de los casos.

A pesar que Colombia ratificó la CDN con la Ley 12 de 1991, el proceso fue lento y se vino a consolidar casi una década después. 


\section{CAPÍTULO 3: Análisis de sentencias: situación de las víctimas en casos de ASI en Boyacá}

\subsection{Descripción metodológica.}

Como ya se indicó anteriormente para este estudio se seleccionaron 24 sentencias de la base de datos de la relatoría Sala Penal del Tribunal Superior del Distrito Judicial de Tunja de fallos emitidos en el periodo 2011- 2018 considerando que este periodo es suficiente para permitirnos obtener la respuesta a la pregunta planteada al inicio del trabajo y además porque la fuente utilizada para la información posee la información necesaria y un alto grado de confiabilidad.

Mediante el uso de una matriz se buscó identificar la problemática por las cuales atraviesa la víctima en desarrollo del proceso judicial y la efectiva ayuda recibida por el Estado colombiano mediante la aplicación de las políticas públicas y que permitieron responder la pregunta de investigación; para poder lograr este resultado, las sentencias se examinaron mediante una ficha en la que se incluyeron aspectos como la información básica, los aspectos a analizar y problemática presentada por las victimas ante las políticas públicas y el desarrollo del proceso judicial.

En el estudio se tendrá en cuenta aspectos como tipo de abusador, parentesco, o grado de cercanía con la víctima, familia y entorno social en que se desenvuelve la victima

Así mismo se analizará la efectividad de los programas de atención a las victimas implementadas por el Estado colombiano a través de sus políticas públicas y el papel del sistema judicial ante este abuso y se revisará si en los casos en estudio se cumplieron las normas tanto nacionales como internacionales para la protección y atención de los NNA objetos de este estudio.

\subsection{Recolección de la información.}

Se solicitaron y obtuvieron de la relatoría del Tribunal Superior del Distrito Judicial de Tunja, sala penal un total de 21 sentencias de segunda instancia; no obstante, en las sentencias de segunda instancia también se incluyó las actuaciones de primera instancia y de los juzgados de primera instancia otra tres para un total de 24 , sumando un gran total de 48 sentencias en el periodo comprendido entre 2011 y 2018 lo que nos da una línea de tiempo de 8 años que se puede considerar que da la certeza y la confiabilidad necesaria a la fuente. 


\subsection{Sentencias objeto del análisis.}

Tabla No 5

\begin{tabular}{|c|c|c|c|c|c|c|}
\hline - & SENTENCIA O CUI & $\begin{array}{c}\text { VICTIM } \\
\text { A }\end{array}$ & $\begin{array}{c}\text { PROCESAD } \\
0\end{array}$ & RADICADO No & $\begin{array}{c}\text { AUTORIDAD } \\
\text { COMPETEN } \\
\text { TE }\end{array}$ & $\begin{array}{l}\text { HECHO } \\
\text { PUNIBLE }\end{array}$ \\
\hline 1 & $\begin{array}{c}\text { SENTENCIA P- N.o } 0120 \\
\text { del } 27 / 1 / 2016\end{array}$ & $\begin{array}{l}\text { L.M.G. } \\
\text { M. }\end{array}$ & $\begin{array}{c}\text { DIEGO } \\
\text { APOLINAR } \\
\text { GARCIA } \\
\text { QUINTERO }\end{array}$ & 2014/0072 & $\begin{array}{c}\text { TRIBUNAL } \\
\text { SUPERIOR } \\
\text { DEL } \\
\text { DISTRITO } \\
\text { JUDICIAL DE } \\
\text { TUNJA } \\
\text { SALA DE } \\
\text { DECISIÓN } \\
\text { PENAL }\end{array}$ & $\begin{array}{c}\text { ACTO } \\
\text { SEXUAL CON } \\
\text { MENOR DE } \\
\text { CATORCE } \\
\text { AÑOS }\end{array}$ \\
\hline 2 & $\begin{array}{c}\text { SENTENCIA P- N. } 033 \text { del } \\
6 / 5 / 2016\end{array}$ & D.L.P.C. & $\begin{array}{c}\text { JHON } \\
\text { ALEJANDRO } \\
\text { RODRÍGUEZ } \\
\text { PÁEZ }\end{array}$ & 2014/0330 & $\begin{array}{c}\text { TRIBUNAL } \\
\text { SUPERIOR } \\
\text { DEL } \\
\text { DISTRITO } \\
\text { JUDICIAL DE } \\
\text { TUNJA } \\
\text { SALA DE } \\
\text { DECISIÓN } \\
\text { PENAL }\end{array}$ & $\begin{array}{c}\text { ACTO } \\
\text { SEXUAL CON } \\
\text { MENOR DE } \\
\text { CATORCE } \\
\text { AÑOS }\end{array}$ \\
\hline 3 & $\begin{array}{c}\text { SENTENCIA P- N.o } 029 \text { del } \\
16 / 6 / 2016\end{array}$ & A.R.F. & $\begin{array}{l}\text { SEGUNDO } \\
\text { TEGOLO } \\
\text { FORERO } \\
\text { MORALES }\end{array}$ & 2014/0368 & $\begin{array}{c}\text { TRIBUNAL } \\
\text { SUPERIOR } \\
\text { DEL } \\
\text { DISTRITO } \\
\text { JUDICIAL DE } \\
\text { TUNJA SALA } \\
\text { DE } \\
\text { DECISION } \\
\text { PENAL }\end{array}$ & $\begin{array}{c}\text { ACTO } \\
\text { SEXUAL CON } \\
\text { MENOR DE } \\
\text { CATORCE } \\
\text { AÑOS }\end{array}$ \\
\hline 4 & $\begin{array}{c}\text { SENTENCIA P- N. } 089 \text { del } \\
16 / 86 / 2018\end{array}$ & Y.T.T. & $\begin{array}{l}\text { PEDRO } \\
\text { ANTONIO } \\
\text { PARRA } \\
\text { IBAÑEZ }\end{array}$ & $2016 / 0808$ & $\begin{array}{c}\text { TRIBUNAL } \\
\text { SUPERIOR } \\
\text { DEL } \\
\text { DISTRITO } \\
\text { JUDICIAL DE } \\
\text { TUNJA SALA } \\
\text { DE } \\
\text { DECISIÓN } \\
\text { PENAL }\end{array}$ & $\begin{array}{c}\text { ACCESO } \\
\text { CARNAL } \\
\text { VIOLENTO }\end{array}$ \\
\hline 5 & $\begin{array}{c}\text { SENTENCIA P- N.ㅇ } 0126 \\
\text { del } 17 / 1 / 2019\end{array}$ & J.C.B. P & $\begin{array}{c}\text { JOSÉ } \\
\text { ANTONIO } \\
\text { REINA } \\
\text { RODRÍGUEZ }\end{array}$ & $2017 / 0460$ & $\begin{array}{c}\text { TRIBUNAL } \\
\text { SUPERIOR } \\
\text { DEL } \\
\text { DISTRITO } \\
\text { JUDICIAL DE } \\
\text { TUNJA SALA } \\
\text { DE } \\
\text { DECISIÓN } \\
\text { PENAL }\end{array}$ & $\begin{array}{c}\text { ACCESO } \\
\text { CARNAL } \\
\text { VIOLENTO }\end{array}$ \\
\hline
\end{tabular}




\begin{tabular}{|c|c|c|c|c|c|c|}
\hline 6 & $\begin{array}{c}\text { SENTENCIA P- N.o } 017 \text { del } \\
12 / 4 / 2019\end{array}$ & $\begin{array}{l}\text { A.M.Z.G } \\
\text {.y } \\
\text { J.N.B.M. }\end{array}$ & $\begin{array}{c}\text { EDUARDO } \\
\text { ERNESTO } \\
\text { CANTOR } \\
\text { ÁVILA }\end{array}$ & 2018-0186-01 & $\begin{array}{c}\text { TRIBUNAL } \\
\text { SUPERIOR } \\
\text { DEL } \\
\text { DISTRITO } \\
\text { JUDICIAL DE } \\
\text { TUNJA } \\
\text { SALA DE } \\
\text { DECISION } \\
\text { PENAL }\end{array}$ & $\begin{array}{c}\text { ACTO } \\
\text { SEXUAL CON } \\
\text { MENOR DE } \\
\text { CATORCE } \\
\text { AÑ̃S }\end{array}$ \\
\hline 7 & $\begin{array}{c}\text { SENTENCIA P- N.․ } 025 \text { del } \\
19 / 4 / 2018\end{array}$ & $\begin{array}{l}\text { L. M. G. } \\
\text { A. }\end{array}$ & $\begin{array}{c}\text { LUIS } \\
\text { ABELARDO } \\
\text { RODRÍGUEZ } \\
\text { GIL }\end{array}$ & 2016-0697-01 & $\begin{array}{c}\text { TRIBUNAL } \\
\text { SUPERIOR } \\
\text { DEL } \\
\text { DISTRITO } \\
\text { JUDICIAL DE } \\
\text { TUNJA } \\
\text { SALA DE } \\
\text { DECISION } \\
\text { PENAL }\end{array}$ & $\begin{array}{c}\text { ACCESO } \\
\text { CARNAL } \\
\text { ABUSIVO } \\
\text { AGRAVADO } \\
\text { EN } \\
\text { CONCURSO } \\
\text { HOMOGÉNE } \\
\text { OY } \\
\text { SUCESIVO }\end{array}$ \\
\hline 8 & $\begin{array}{c}\text { SENTENCIA P- N. } 0056 \text { del } \\
26 / 7 / 2019\end{array}$ & AMRG & $\begin{array}{l}\text { PEDRO } \\
\text { JOSÉ LÓPEZ } \\
\text { ARIAS }\end{array}$ & 2017-0965-01 & $\begin{array}{c}\text { TRIBUNAL } \\
\text { SUPERIOR } \\
\text { DEL } \\
\text { DISTRITO } \\
\text { JUDICIAL DE } \\
\text { TUNJA } \\
\text { SALA DE } \\
\text { DECISION } \\
\text { PENAL }\end{array}$ & $\begin{array}{c}\text { ACCESO } \\
\text { CARNAL } \\
\text { ABUSIVO } \\
\text { CON MENOR } \\
\text { DE CATORCE } \\
\text { AÑOS }\end{array}$ \\
\hline 9 & $\begin{array}{c}\text { SENTENCIA P- N.o } 064 \text { del } \\
1 / 9 / 2016\end{array}$ & $\begin{array}{l}\text { E.Y.M. } \\
\text { M. }\end{array}$ & $\begin{array}{l}\text { CARLOS } \\
\text { JULIO } \\
\text { MARTÍN } \\
\text { MARTíN }\end{array}$ & $2015-0681$ & $\begin{array}{c}\text { TRIBUNAL } \\
\text { SUPERIOR } \\
\text { DEL } \\
\text { DISTRITO } \\
\text { JUDICIAL DE } \\
\text { TUNJA } \\
\text { SALA DE } \\
\text { DECISION } \\
\text { PENAL }\end{array}$ & $\begin{array}{c}\text { ACCESO } \\
\text { CARNAL } \\
\text { ABUSIVO } \\
\text { CON MENOR } \\
\text { DE CATORCE } \\
\text { AÑOS }\end{array}$ \\
\hline 10 & $\begin{array}{c}\text { SENTENCIA P- N.. } 066 \text { del } \\
28 / 7 / 2017\end{array}$ & $\begin{array}{l}\text { J.P.R.S y } \\
\text { A.T.C. B }\end{array}$ & $\begin{array}{l}\text { MAURO } \\
\text { EDMUNDO } \\
\text { ACOSTA } \\
\text { GALINDO }\end{array}$ & 2015-0777-01 & $\begin{array}{c}\text { TRIBUNAL } \\
\text { SUPERIOR } \\
\text { DEL } \\
\text { DISTRITO } \\
\text { JUDICIAL DE } \\
\text { TUNJA } \\
\text { SALA DE } \\
\text { DECISION } \\
\text { PENAL }\end{array}$ & $\begin{array}{c}\text { ACTO } \\
\text { SEXUAL CON } \\
\text { MENOR DE } \\
\text { CATORCE } \\
\text { AÑOS }\end{array}$ \\
\hline 11 & $\begin{array}{c}\text { SENTENCIA P- N.o } 068 \text { del } \\
13 / 8 / 2018\end{array}$ & A.T.R. A & $\begin{array}{c}\text { JOSÉ } \\
\text { VICENTE } \\
\text { MORA }\end{array}$ & $2017-00130$ & $\begin{array}{c}\text { TRIBUNAL } \\
\text { SUPERIOR } \\
\text { DEL } \\
\text { DISTRITO } \\
\text { JUDICIAL DE } \\
\text { TUNJA } \\
\text { SALA DE } \\
\text { DECISION } \\
\text { PENAL }\end{array}$ & $\begin{array}{c}\text { ACCESO } \\
\text { CARNAL O } \\
\text { ACTO } \\
\text { SEXUAL } \\
\text { ABUSIVO } \\
\text { CON } \\
\text { INCAPAZ DE } \\
\text { RESISTIR }\end{array}$ \\
\hline & & A.L.B.C. & & 2015-0369 & $\begin{array}{c}\text { TRIBUNAL } \\
\text { SUPERIOR } \\
\text { DEL } \\
\text { DISTRITO }\end{array}$ & $\begin{array}{c}\text { ACTOS } \\
\text { SEXUALES } \\
\text { CON MENOR }\end{array}$ \\
\hline
\end{tabular}




\begin{tabular}{|c|c|c|c|c|c|c|}
\hline 12 & $\begin{array}{c}\text { SENTENCIA P- N.o } 084 \text { del } \\
7 / 12 / 2016\end{array}$ & & $\begin{array}{l}\text { FERNANDO } \\
\text { CATÓLICO } \\
\text { DAZA }\end{array}$ & & $\begin{array}{l}\text { JUDICIAL DE } \\
\text { TUNJA } \\
\text { SALA DE } \\
\text { DECISION } \\
\text { PENAL }\end{array}$ & $\begin{array}{l}\text { DE CATORCE } \\
\text { AÑOS } \\
\text { AGRAVADO }\end{array}$ \\
\hline 13 & $\begin{array}{c}\text { SENTENCIA P- N.o } 086 \text { del } \\
\text { 8/11/2016 }\end{array}$ & D.E. G & $\begin{array}{l}\text { JOSÉ DE } \\
\text { JESÚS } \\
\text { CAÑÓN }\end{array}$ & $2015-06018$ & $\begin{array}{c}\text { TRIBUNAL } \\
\text { SUPERIOR } \\
\text { DEL } \\
\text { DISTRITO } \\
\text { JUDICIAL DE } \\
\text { TUNJA } \\
\text { SALA DE } \\
\text { DECISION } \\
\text { PENAL }\end{array}$ & $\begin{array}{c}\text { ACTOS } \\
\text { SEXUALES } \\
\text { VIOLENTOS, } \\
\text { AGRAVADO }\end{array}$ \\
\hline 14 & $\begin{array}{c}\text { SENTENCIA P- N.o } 135 \text { del } \\
\text { 18/1/2019 }\end{array}$ & $\begin{array}{l}\text { D.M.M. } \\
\text { F }\end{array}$ & $\begin{array}{c}\text { HÉCTOR } \\
\text { EMILIO } \\
\text { MORENO } \\
\text { CABALLERO }\end{array}$ & 2017-0748-01 & $\begin{array}{c}\text { TRIBUNAL } \\
\text { SUPERIOR } \\
\text { DEL } \\
\text { DISTRITO } \\
\text { JUDICIAL DE } \\
\text { TUNJA } \\
\text { SALA DE } \\
\text { DECISION } \\
\text { PENAL }\end{array}$ & $\begin{array}{c}\text { ACCESO } \\
\text { CARNAL } \\
\text { ABUSIVO } \\
\text { CON MENOR } \\
\text { DE CATORCE } \\
\text { AÑOS } \\
\text { AGRAVADO } \\
\text { EN } \\
\text { CONCURSO } \\
\text { HOMOGÉNE } \\
\text { OY } \\
\text { SUCESIVO }\end{array}$ \\
\hline 15 & $\begin{array}{c}\text { SENTENCIA P- N.o } 016 \text { del } \\
15 / 4 / 2016\end{array}$ & $\begin{array}{l}\text { I.Y.G.A. } \\
\text { M.D.L.R } \\
\text { K.S.G.Z }\end{array}$ & $\begin{array}{c}\text { JOSÉ } \\
\text { FRANCISCO } \\
\text { CORONAD } \\
\text { O NARANJO }\end{array}$ & 2015-0106 & $\begin{array}{l}\text { TRIBUNAL } \\
\text { SUPERIOR } \\
\text { DEL } \\
\text { DISTRITO } \\
\text { JUDICIAL DE } \\
\text { TUNJA } \\
\text { SALA DE } \\
\text { DECISION } \\
\text { PENAL }\end{array}$ & $\begin{array}{c}\text { ACCESO } \\
\text { CARNAL } \\
\text { VIOLENTO EN } \\
\text { CONCURSO } \\
\text { HOMOGÉNE } \\
\text { OY } \\
\text { SUCESIVO, } \\
\text { EN } \\
\text { CONCURSO } \\
\text { HETEROGÉNE } \\
\text { O CON } \\
\text { SUMINISTRO } \\
\text { A MENOR DE } \\
\text { DROGA QUE } \\
\text { PRODUZCA } \\
\text { DEPENDENCI } \\
\text { A }\end{array}$ \\
\hline 16 & $\begin{array}{c}\text { SENTENCIA P- N.o } 020 \text { del } \\
\text { 9/3/2018 }\end{array}$ & CAMC & $\begin{array}{l}\text { SEGUNDO } \\
\text { SALOMÓN } \\
\text { ROJAS } \\
\text { MONROY }\end{array}$ & $\begin{array}{c}154696103189201080100 \\
(2017-0122) .\end{array}$ & $\begin{array}{c}\text { TRIBUNAL } \\
\text { SUPERIOR } \\
\text { DEL } \\
\text { DISTRITO } \\
\text { JUDICIAL DE } \\
\text { TUNJA } \\
\text { SALA DE } \\
\text { DECISION } \\
\text { PENAL }\end{array}$ & $\begin{array}{c}\text { ACTO } \\
\text { SEXUAL CON } \\
\text { MENOR DE } \\
\text { CATORCE } \\
\text { AÑ̃S }\end{array}$ \\
\hline & $\begin{array}{c}\text { SENTENCIA P- N.o } 039 \text { del } \\
13 / 6 / 2016\end{array}$ & & $\begin{array}{l}\text { TIBERIO } \\
\text { JOSÉ }\end{array}$ & & $\begin{array}{c}\text { TRIBUNAL } \\
\text { SUPERIOR } \\
\text { DEL } \\
\text { DISTRITO }\end{array}$ & $\begin{array}{c}\text { ACTOS } \\
\text { SEXUALES } \\
\text { CON MENOR } \\
\text { DE CATORCE }\end{array}$ \\
\hline
\end{tabular}




\begin{tabular}{|c|c|c|c|c|c|c|}
\hline 17 & & $\begin{array}{l}\text { J.M.G. } \\
\text { M. }\end{array}$ & $\begin{array}{l}\text { GUERRA } \\
\text { FORERO }\end{array}$ & $\begin{array}{c}410016001279200900051(2 \\
014-0610)\end{array}$ & $\begin{array}{l}\text { JUDICIAL DE } \\
\text { TUNJA } \\
\text { SALA DE } \\
\text { DECISION } \\
\text { PENAL }\end{array}$ & $\begin{array}{c}\text { AÑOS } \\
\text { AGRAVADO } \\
\text { EN } \\
\text { CONCURSO } \\
\text { HOMOGÉNE } \\
\text { OY } \\
\text { SUCESIVO. }\end{array}$ \\
\hline 18 & $\begin{array}{c}\text { SENTENCIA P- N.o 051del } \\
31 / 5 / 2017\end{array}$ & D.A.N.R & $\begin{array}{c}\text { NESTOR } \\
\text { ARMANDO } \\
\text { NAUSAN } \\
\text { RODRIGUEZ }\end{array}$ & 2014-0061 & $\begin{array}{c}\text { TRIBUNAL } \\
\text { SUPERIOR } \\
\text { DEL } \\
\text { DISTRITO } \\
\text { JUDICIAL DE } \\
\text { TUNJA } \\
\text { SALA DE } \\
\text { DECISION } \\
\text { PENAL }\end{array}$ & $\begin{array}{c}\text { ACCESO } \\
\text { CARNAL } \\
\text { ABUSIVO } \\
\text { CON MENOR } \\
\text { DE CATORCE } \\
\text { AÑOS, } \\
\text { AGRAVADO }\end{array}$ \\
\hline 19 & $\begin{array}{c}\text { SENTENCIA P- N.o } 059 \text { del } \\
26 / 7 / 2017\end{array}$ & $\begin{array}{l}\text { A.M.S. } \\
\text { A }\end{array}$ & $\begin{array}{c}\text { JHON } \\
\text { FREDY } \\
\text { AVELLANED } \\
\text { A } \\
\text { MENDIVELS } \\
0\end{array}$ & $\begin{array}{c}151766000110201300197 \\
(20140616)\end{array}$ & $\begin{array}{c}\text { TRIBUNAL } \\
\text { SUPERIOR } \\
\text { DEL } \\
\text { DISTRITO } \\
\text { JUDICIAL DE } \\
\text { TUNJA } \\
\text { SALA DE } \\
\text { DECISION } \\
\text { PENAL } \\
\end{array}$ & $\begin{array}{c}\text { ACCESO } \\
\text { CARNAL } \\
\text { ABUSIVO } \\
\text { CON MENOR } \\
\text { DE CATORCE } \\
\text { AÑOS }\end{array}$ \\
\hline 20 & $\begin{array}{c}\text { SENTENCIA P- N.o } 062 \text { del } \\
30 / 6 / 2017\end{array}$ & E.Y.D. B & $\begin{array}{l}\text { RODOLFO } \\
\text { PALACIOS } \\
\text { CORREDOR }\end{array}$ & $\begin{array}{c}110016000013201000208 \\
(2015-0663)\end{array}$ & $\begin{array}{c}\text { TRIBUNAL } \\
\text { SUPERIOR } \\
\text { DEL } \\
\text { DISTRITO } \\
\text { JUDICIAL DE } \\
\text { TUNJA SALA } \\
\text { DE } \\
\text { DECISION } \\
\text { PENAL }\end{array}$ & $\begin{array}{c}\text { ACTO } \\
\text { SEXUAL CON } \\
\text { MENOR DE } \\
\text { CATORCE } \\
\text { AÑ̃S }\end{array}$ \\
\hline 21 & $\begin{array}{c}\text { SENTENCIA P- N.o } 079 \text { del } \\
22 / 8 / 2016\end{array}$ & V.P.F.R. & $\begin{array}{c}\text { JOSÉ } \\
\text { EUDILIO } \\
\text { ESCALA } \\
\text { SIERRA }\end{array}$ & $\begin{array}{c}151766000110200900366 \\
(2013-0088)\end{array}$ & $\begin{array}{c}\text { TRIBUNAL } \\
\text { SUPERIOR } \\
\text { DEL } \\
\text { DISTRITO } \\
\text { JUDICIAL DE } \\
\text { TUNJA SALA } \\
\text { DE } \\
\text { DECISION } \\
\text { PENAL }\end{array}$ & $\begin{array}{c}\text { ACTO } \\
\text { SEXUAL CON } \\
\text { MENOR DE } \\
\text { CATORCE } \\
\text { AÑOS }\end{array}$ \\
\hline 22 & $\begin{array}{c}\text { CUI } \\
11001600072120120007 \\
501\end{array}$ & D.R.R.F. & $\begin{array}{c}\text { FREDY } \\
\text { HERNAN } \\
\text { VILLAMOR } \\
\text { MARTINEZ }\end{array}$ & $\begin{array}{c}\text { CUI } \\
11001600072120120007501\end{array}$ & $\begin{array}{c}\text { JUZGADO } \\
\text { PROMISCUO } \\
\text { DEL } \\
\text { CIRCUITO } \\
\text { DE } \\
\text { MIRAFLORE } \\
\text { S } \\
\end{array}$ & $\begin{array}{c}\text { ACCESO } \\
\text { CARNAL } \\
\text { ABUSIVO } \\
\text { CON MENOR } \\
\text { DE } 14 \text { AÑOS }\end{array}$ \\
\hline 23 & $\begin{array}{c}15455600011820130015 \\
900\end{array}$ & L.F.M. R & $\begin{array}{l}\text { PEDRO } \\
\text { GIRALDO } \\
\text { LOAIZA }\end{array}$ & 15455600011820130015900 & $\begin{array}{c}\text { JUZGADO } \\
\text { PROMISCUO } \\
\text { DEL } \\
\text { CIRCUITO } \\
\text { DE } \\
\text { MIRAFLORE } \\
\text { S }\end{array}$ & $\begin{array}{c}\text { ACTO } \\
\text { SEXUAL } \\
\text { ABUSIVO } \\
\text { AGRAVADO }\end{array}$ \\
\hline
\end{tabular}




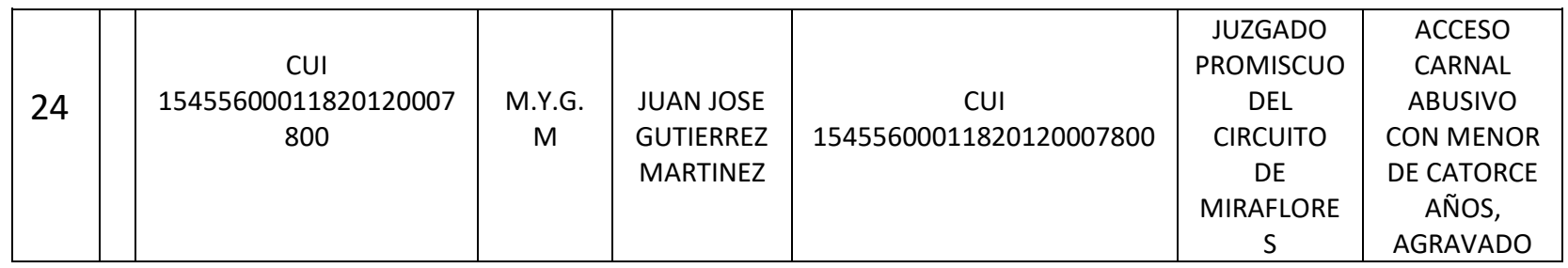

\subsection{Elaboración ficha para análisis.}

Tabla 6

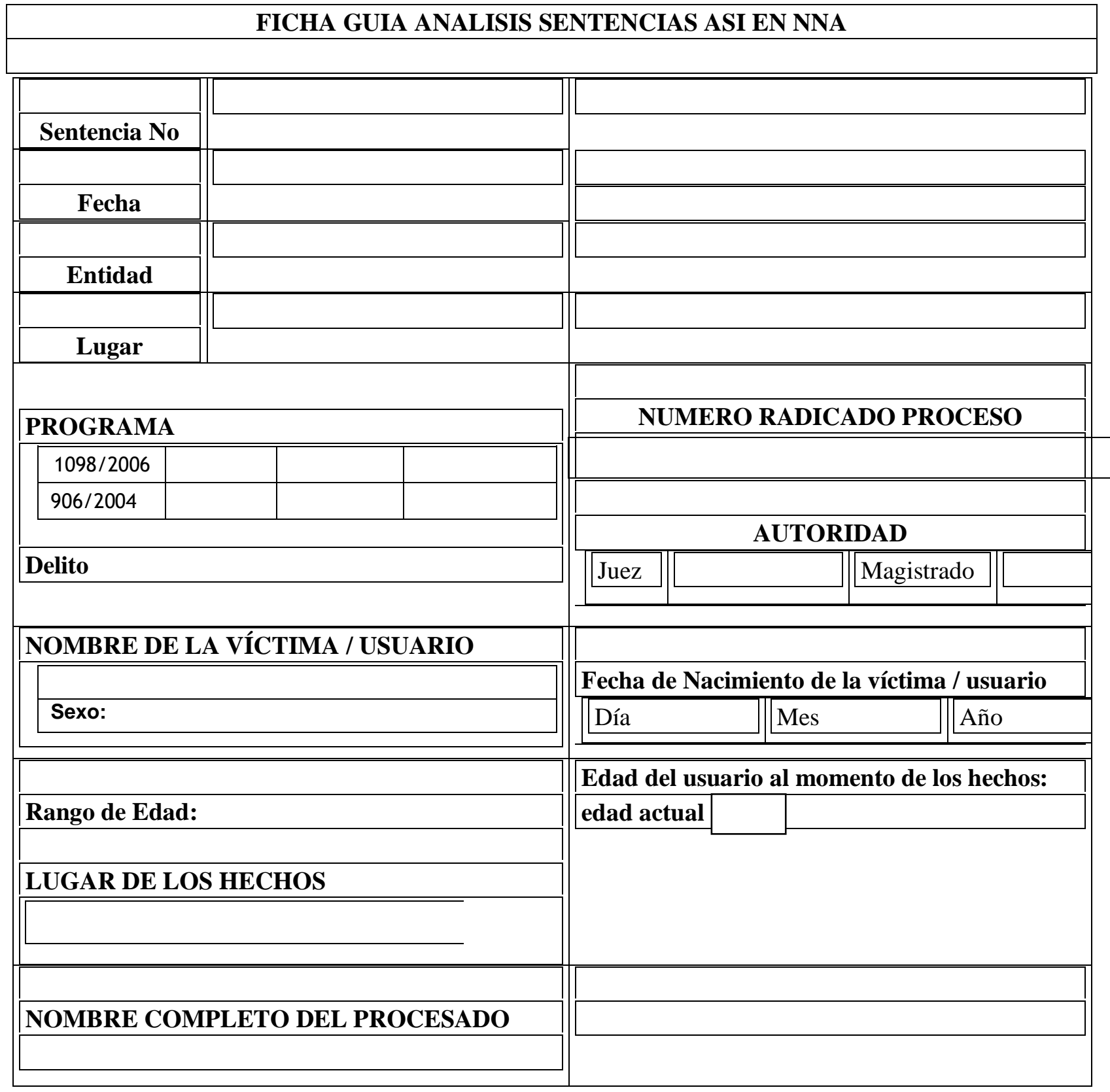




\begin{tabular}{|l||l||l|}
\hline $\begin{array}{l}\text { Tipificación de } \\
\text { la conducta }\end{array}$ & & \\
\hline
\end{tabular}




\subsection{Aspectos a analizar para determinar la situación de las víctimas de ASI.}

Una vez enmarcada el ASI dentro de la normatividad nacional e internacional y debidamente definidos y conceptualizados los conceptos referentes al tema se procede a realizar el análisis de las sentencias desde varios aspectos importantes, que constituyen las variables que nos permitirán establecer la situación de las victimas frente a la atención del Estado y frente al proceso judicial, así como los efectos que este delito les ha ocasionado en todos sus ámbitos.

Se realizo el análisis con base en los siguientes criterios:

Aplicación de los instrumentos de protección y atención para las víctimas de ASI establecidos por las Políticas Públicas.

Seguimiento de los protocolos para la realización de los diferentes procedimientos (entrevistas, exámenes, testimonios) según los lineamientos de los tratados internacionales y la metodología descrita para la atención de los NNA víctimas de ASI.

Conocimiento de los operadores judiciales de los estándares internacionales en protección de las víctimas de ASI.

Debida diligencia por parte de los operadores judiciales al momento de investigar y realizar el proceso judicial.

Conocimiento de los jueces y magistrados de la normatividad nacional e internacional y la jurisprudencia al momento de valorar los testimonios de las víctimas.

Articulación de las entidades encargadas de la protección de los NNA.

Aplicación de la normatividad colombiana y la jurisprudencia en el desarrollo del proceso judicial teniendo en cuenta el interés superior de los NNA. 


\subsubsection{Aplicación de los instrumentos}

\subsubsection{1- Aplicación de los instrumentos de protección y atención para las víctimas de ASI establecidos por las Políticas Públicas.}

El abuso sexual sigue siendo uno de los peligros más grandes a los cuales los NNA están expuestos. Esta problemática se ha convertido en algo tan común que para la misma sociedad a veces se hace invisible o tan cotidiana que la indolencia o la resignación o la misma indignación ya no representan una situación fuera de lo común a no ser que se trate de situaciones de extrema violencia.

Sin embargo, para las victimas este será un dolor y un estigma que hace mella por que la degrada y deshumaniza, dejándole secuelas que llevara por el resto de su vida.

En el año de 2000 el Estado colombiano a través del ministerio de la protección social desarrollo la denominada Guía del Menor Maltratado como parte de las políticas públicas tendientes a solucionar la problemática del ASI, básicamente esta guía indicaba las acciones que el las instituciones gubernamentales y muy especialmente las del sector de salud deberían realizar frente a la problemática y que se instituyeron en protocolos acordes con el Derecho Internacional Humanitario.

Se preciso que se debería realizar la atención de las víctimas de forma humana y profesional tendientes a minimizar las consecuencias y se estableció el compromiso de iniciar acciones para la protección y no repetición de otras formas de violencia.

De igual manera se estipulo que la atención tendría que garantizar un trato humano, digno y reparador; unos procedimientos estandarizados y efectivos para controlar los daños sobre su salud sexual y reproductiva, su salud mental y su medio familiar y social; y se deberían garantizar los insumos médicos necesarios para la aplicación de dichos procedimientos e intervenciones.

El objetivo de esto es aminorar la severidad de las consecuencias y el impacto del ASI que de acuerdo con las victimas será diferente en cada caso, y tendrá repercusiones importantes 
dependiendo de las circunstancias en que ocurrió el hecho, la calidad y oportunidad de los apoyos sociales recibidos, el tiempo de ocurrencia, la cercanía con el agresor, entre otros factores.

Según los protocolos establecidos en las políticas públicas se debe realizar una atención integral en donde se integren todas las disciplinas como la salud, las ciencias sociales, la atención jurídica y psicológica que dé cuenta de las diferentes necesidades (bio-psico-sociales) de las víctimas y la sanción de los agresores.

Desde este punto de vista la atención integral a las víctimas de ASI y al núcleo familiar debe propender por la atención, recuperación y protección integral, desde una perspectiva de la restitución de derechos.

Se debe tener en cuenta que lo primordial es el ser humano, lo que significa que lo primero es la víctima, no su declaración o su familia, o las evidencia, o el juicio o las autoridades de policía o los operadores judiciales.

De acuerdo con lo anterior, el Derecho Internacional Humanitario, y la normativa colombiana se requiere dar a las víctimas: apoyo emocional, tratar las condiciones generales de salud relacionadas con el ASI (emergencias médicas/psicológicas-trauma, intoxicaciones, cuidado general de la salud, etc.), profilaxis de ITS y VIH, hepatitis B, IVE, etc., tomar evidencias forenses cuando aplique, dar las medidas de protección de las víctimas, suministrar el tratamiento y rehabilitación de su salud mental, dar la orientación a la familia, activar las distintas redes de apoyo institucional, comunitario y familiar que permitan su atención integral.

Así lo contempla la ley 1164 de 2007, que propugna por la humanidad, dignidad, responsabilidad, la prudencia y el secreto.

De igual manera la Ley 1257 de 2008, trae que las víctimas de ASI o violencia sexual tienen derecho a recibir atención integral a través de servicios con cobertura suficiente, accesible y de la calidad, recibir información clara, completa, veraz y oportuna en relación con sus derechos, dar su consentimiento informado para los exámenes médicos y legales, escoger el sexo del facultativo para la práctica de los mismos dentro de las posibilidades ofrecidas por el servicio, recibir información clara, completa, veraz y oportuna en relación con la salud sexual y reproductiva, ser tratada con 
reserva de identidad al recibir la asistencia médica, legal, o asistencia social respecto de sus datos personales, los de sus descendientes o los de cualquiera otra persona que esté bajo su guarda o custodia, recibir asistencia médica, psicológica, psiquiátrica y forense especializada e integral en los términos y condiciones establecidos en el ordenamiento jurídico para ellas y sus hijos e hijas.

En el análisis de las sentencia se encontró que en todos los casos se realizaron los exámenes sexológicos por parte de profesionales de la medicina y se llevaron a cabo entrevistas y valoraciones tanto por parte de las comisarías de familia como por grupos de psicólogos del ICBF y del INML, no obstante estos procedimientos fueron realizados únicamente con el propósito de ser utilizados por los operadores judiciales y los profesionales del derecho para establecer la veracidad del hecho punible y así condenar u absolver al indiciado.

En la sentencia SP 01262017-460 se observa que la Psicóloga del INML, conceptúa que el menor presenta ansiedad y temor, síntomas estos de depresión y sentimientos de estigmatización ${ }^{1}$; de igual forma afirma que no realizo la correcta anotación de todas las preguntas realizadas, ni grabo la entrevista, que realizo una sola entrevista y que no aplico material psicotécnico a pesar que esto lo exige el artículo 47 del Código Bioético de la Psicología²

En la sentencia $20140368^{3}$, igualmente los psicólogos que realizaron las valoraciones encontraron en la victima signos de inseguridad, sentimientos de hostilidad hacia la figura masculina, ansiedad, malestar psicológico inhibición y retraimiento situación que se evidencia de igual forma las sentencias $20140330^{4}$.

La sentencia SP $-017^{5}$ muestra que a pesar que una de las victimas había sido objeto de intervención por parte del ICBF, no se le protegieron sus derechos, aunque presentaba deficiencias cognoscitivas evidentes, no se hizo un seguimiento ni se le valoro porque según el ICBF eso no procede en caso de restitución de derechos, este concepto claramente va en contravía de los protocolos internacionales en materia de protección de NNA y tuvo que ser objeto de ASI para así acceder a valoraciones psicológicas por parte de las instituciones gubernamentales.

\footnotetext{
${ }^{1}$ Tribunal Superior del Distrito Judicial de Tunja, SP 01262017-460, pág. 46.

2 Tribunal Superior del Distrito Judicial de Tunja, SP 01262017-460, pág. 33.

${ }^{3}$ Tribunal Superior del Distrito Judicial de Tunja, SP 2014 0368-029, pág. 12.

${ }^{4}$ Tribunal Superior del Distrito Judicial de Tunja, SP 2014 0330-033, pág. 4.

${ }^{5}$ Tribunal Superior del Distrito Judicial de Tunja, SP 2018-0186-01-017, pág. 121.
} 
En la sentencia SP 025, se observa que la víctima quedo en estado de embarazo por la violación a que fue objeto en reiteradas ocasiones, pero no se le presto ningún tipo de ayuda psicológica siendo que se trataba de una niña criando a otra niña con las consecuencias de tipo psicológico y social que esto entraña.

Según las normas del DIH dar una asistencia integral a las víctimas de ASI implica ir más allá de la sanación física, es crear los medios que garanticen también su recuperación emocional, sexual, social, que obtengan no solo la justicia a que tienen derecho legalmente, sino que su vida pueda ser retomada sin ningún tipo de secuela o estigma social.

Desde este punto de vista no se encuentra por lado alguno en el análisis de las sentencia estudiadas que a las víctimas se les haya brindado una asistencia psicológica para tratar de superar las consecuencias del abuso; pues como se colige de las sentencias no se hizo seguimiento a las víctimas, no se les proveyó de una ayuda psicológica de apoyo ni al entorno familiar, ni dentro del desarrollo del proceso ni posteriormente sino únicamente se cumplió con lo básico en la indagación, además en ninguna de las providencias se ordena realizarse procesos terapéuticos que puedan ayudar a la superación de las consecuencias y secuelas del abuso sufrido.

Tampoco se evidencia que se hayan aplicado los protocolos existentes en la materia y regulados por el ministerio de la protección social y el ICBF, lo que se traduce en que a pesar de existir los protocolos estos no se aplican por parte de las entidades encargadas de hacerlo ya sea por falta de presupuesto o por no tener la logística o desconocimiento de los encargados de llevarlos a cabo.

\subsubsection{2.- Seguimiento de los protocolos para la realización de los diferentes procedimientos (entrevistas, exámenes, testimonios) según los lineamientos de los tratados internacionales y la metodología descrita para la atención de los NNA víctimas de ASI.}

La Ley 1257 de 2008, la Ley 1448 de 2011 y la Ley 1719 de 2014 reconocen los derechos de las víctimas de abuso sexual y por ende son aplicables en el caso del ASI a los NNA; dentro de estos se encuentra el derecho a la verdad, a la justicia y a que los recursos judiciales sean efectivos en procura de estos objetivos 
Además, tienen derecho al respeto a y a la debida protección de su intimidad y privacidad, así como a su dignidad y a no ser revictimizada, ni discriminada teniendo por esta razón derecho a participar en el proceso penal con un acompañamiento y una asistencia técnica legal sin que su derecho sea menoscabado por los operadores judiciales o por otras de las partes participantes en el mismo, además que sus derechos deben ser restablecidos y protegida su salud tanto física como mental y la de su grupo familiar.

Esto significa que todos los procedimientos tanto de carácter medico como los que atañen a la salud mental de la víctima deben cumplir con un proceso que comienza con los exámenes médicos físicos, la toma de muestras forenses si las hubiere y todo esto protegido por una cadena de custodia que permita la preservación de los elementos probatorios obtenidos.

De este proceso también hace parte los correspondiente a la realización de entrevistas y valoraciones de tipo psicológico que deben ser lo más estrictos posibles sin que exista influencia de algún tipo sobre lo que relatan las víctimas y todo esto debe estar documentado y actualmente grabado para evitar dilaciones en el proceso porque dentro del marco del sistema penal acusatorio los profesionales que realizaron estos procedimientos pueden ser llamados a declarar sobre los mismos.

Según la Normatividad colombiana ya reseñada se debe realizar el proceso de atención y valoración siguiendo una secuencia que debe ser: entrevista, examen físico y mental, realización de pruebas diagnósticas o de control, y cierre.

En este aspecto es importante resaltar que la atención integral hace énfasis en evitar la revictimización de los NNA víctimas de ASI.

La victima inicialmente sufre la agresión que la deja emocionalmente y físicamente en estado de choque y vulnerabilidad manifiesto.

Posteriormente ocurre el fenómeno de la revictimización que incluye no solo al agredido sino también a su entorno familiar Maxime si la agresión ocurrió en la esfera intima de la misma, dentro del estudio se encontró que esta revictimización es realizada por las entidades encargadas de la atención del paciente y comienza con las mismas entidades prestadoras de salud y el personal que realiza la valoración inicial ( médicos, enfermeras, pediatras, ginecólogos, psicólogos o trabajadores sociales, personal administrativo), continua con las instituciones encargadas de los procesos de investigación e inicio del proceso judicial, (Comisarios de familia, policías, peritos jueces, 
criminólogos, psicólogos forenses, abogados), quienes en muchas ocasiones no tienen claro los procesos y procedimientos para la restitución de los derechos de los NNA víctimas de ASI.

En las sentencias en estudio es una constante este tipo de revictimización por que como puede observarse en las sentencias, SP $025^{6}, 056^{7}, 064^{8}, 068^{9}, 135^{10}, 016,051,059,062,079^{11}$, los NNA son sometidos a más de una valoración médica en tiempos diferentes y de igual manera se verifica que las valoraciones Psicológicas, entrevistas, cámaras Gesell y demás procedimientos se realizan por diferentes profesionales y en periodos de tiempo en ocasiones demasiado largos, lo que no permite que la víctima sane sus heridas psicológicas y por el contrario mantenga vivo el recuerdo de lo sucedido ${ }^{12}$.

Toda esta actuación va en contravía a lo preceptuado en la ley 1164 que postula la dignidad humana como un bien que no puede ser objeto de maltrato por parte de nadie persona o institución, e impone un deber y una responsabilidad a los profesionales tanto de la salud como a los operadores judiciales y demás profesionales intervinientes en el proceso, llama a la prudencia para utilizar los medios menos dañosos a las víctimas, e impone el secreto profesional dentro de los límites de la constitución nacional y la normatividad específica para este tipo de delitos.

\subsubsection{3.- Conocimiento de los operadores judiciales de los estándares internacionales en protección de las víctimas de ASI.}

La Convención Americana sobre Derechos Humanos y la Declaración Americana sobre los Derechos y Deberes del Hombre (en adelante, "Declaración Americana") afirman el derecho de cualquier persona a acceder a un recurso judicial sencillo y eficaz ante denuncias de violaciones a sus derechos, así como la obligación de los Estados de actuar con la debida diligencia para prevenir, investigar y sancionar y reparar estos hechos (www.cidh.org, 2013). La Corte Interamericana de Derechos Humanos (en adelante, "Corte" o "Corte Interamericana") ha explicitado que toda persona que ha sufrido una violación a sus derechos humanos "tiene derecho a obtener de los órganos competentes del Estado el esclarecimiento

\footnotetext{
${ }^{6}$ Tribunal Superior del Distrito Judicial de Tunja, Rad. 2018-0186-01- Sentencia No. 025, pág. 15.

${ }^{7}$ Tribunal Superior del Distrito Judicial de Tunja, Rad. 2017-0965-01- Sentencia No. 0056, pág. 82

${ }^{8}$ Tribunal Superior del Distrito Judicial de Tunja, Rad. 2015-0681-01-Sentencia No. 064, pág. 25

${ }^{9}$ Tribunal Superior del Distrito Judicial de Tunja, Rad. 2017-0130- Sentencia No. 068, pág. 10.

${ }^{10}$ Tribunal Superior del Distrito Judicial de Tunja, Rad. 2017-0748- Sentencia No. 0135 pág. 15,19,22,26.

11 Tribunal Superior del Distrito Judicial de Tunja, Rad. 2009-0366. Sentencia No. 079. Pág. 8 y 21.

12 Tribunal Superior del Distrito Judicial de Tunja, Rad. 2015-0369-01- Sentencia No. 084 pág. 38
} 
de los hechos violatorios y el establecimiento de las responsabilidades correspondientes, a través de la investigación y el juzgamiento que previenen los artículos 8 y 25 de la Convención (www.cidh.org, 2013).

En nuestro ordenamiento jurídico entre los operadores judiciales tenemos a los Jueces, fiscales, policía judicial, peritos y demás profesionales de apoyo del proceso jurídico.

Los jueces tienen el deber de realizar la protección judicial de los derechos violados, así como realizar los procedimientos de acuerdo al debido proceso, en función de lograr imponer la sanción a que haya lugar en caso de cometerse un delito.

Los fiscales por su parte realizan la investigación pertinente, supervisan que todo se realice dentro de la legalidad y velan por la ejecución de los fallos judiciales, son responsables que no exista impunidad, además deben realizar la imputación del delito cuidando que este acorde con la normatividad existente, velando que se ajuste a los tipos penales necesarios y no descuidando su labor para que el delito sea sancionado de acuerdo con la gravedad del mismo.

Los defensores tanto públicos como privados deben asegurar que el Estado cumpla con la obligación de que tanto la victima como el victimario sean objeto del poder punitivo del Estado de acuerdo con la calidad en que se encuentre; son garantes igualmente que se cumplan los debidos procesos y que las victimas obtengan justicia y la debida reparación de sus perjuicios, así como la plena restitución de sus derechos.

Es deber del Estado colombiano garantizar una capacitación permanente que sea accesible a los operadores de justicia.

La capacitación debe estar dirigida especialmente hacia aspectos que versen sobre los derechos humanos y muy especialmente sobre los estandartes internacionales en materia de protección de los NNA víctimas de ASI; pues en Colombia desafortunadamente se tiende a incluir este tema dentro de la violencia sexual dejando de lado que los NNA son objeto de atención especial por parte de las organizaciones internacionales y que mecanismos implementados en documentos como la Convención de los Derechos del niño, la convención de san salvador y Belem de O Para le dan un estatus que prevalece por encima de los derechos de las otras víctimas de violencia sexual.

Desde la orilla internacional y especialmente la CIDH ha propugnado por que los Estados tengan un plan de capacitación a estos operadores judiciales, pero que esta debe ser en materia de 
los derechos de grupos que necesitan un tratamiento especializado, entre estos se encuentran lógicamente los NNA.

Esto con el objeto que al momento de presentarse un caso de este tipo los operadores cuenten con la debida formación para que se apliquen los estándares internacionales en esta materia ya descritos anteriormente garantizando así el respeto a su dignidad, la adecuada participación dentro de los procesos que los involucren y tengan el pleno acceso a la justicia para tener derecho a la reparación integral por los daños sufridos tanto físicos como psicológicos; posibilitando de esta manera que el ASI sea prevenido, investigado y sancionado en los términos del derecho internacional y las normas establecidas para este tipo de delitos.

No obstante, en el desarrollo del proceso en Colombia no se aplican los estándares internacionales esto debido en gran parte a que como ya se dijo la ley 1098 catalogo este tipo de agresión como una forma de maltrato infantil y por esta razón se maneja de acuerdo con la normatividad colombiana.

Por otra parte, las nuevas leyes que endurecen las penas y promueven la protección integral de los NNA, coloca una mayor carga sobre los operadores judiciales, quienes pasan a ejercer como restablecedores de los derechos conculcados, esta presión que se ejerce sobre los jueces puede originar que se cometan errores en el proceso judicial, y que los mismos jueces solo tengan en cuenta la normatividad colombiana y la jurisprudencia nacional, dejando de lado los preceptos internacionales.

En el análisis de las sentencias se halló que el $90 \%$ de los fallos están sustentados en la normatividad y jurisprudencia colombiana, y que en muy pocas ocasiones se hace referencia a los estándares internacionales, esto no implica que los fallos no sean consistentes con el caso investigado, sino que los jueces no han tenido la suficiente capacitación respecto a estos temas.

Básicamente las sentencias muestran una clara tendencia a retomar lo preceptuado por la corte especialmente a lo referente a la validez del testimonio del menor, como se observa en la sentencia SP 056, SP 068, Sp135 del Tribunal Superior del Distrito Judicial de Tunja Sala Penal que traen como referencia las sentencias de la Corte Suprema 23706 de enero de $2006^{13}$, fallo 34568 de febrero de 2011, radicado $35080^{14}$ del 11 de mayo de 2011, radicado 41136 del 8 de agosto de 2016, radicado 23706 de 2006 y otras.

\footnotetext{
13 Tribunal Superior del Distrito Judicial de Tunja, Rad. 2017-0748- Sentencia No. 0135 pág. 11.

${ }^{14}$ Tribunal Superior del Distrito Judicial de Tunja, Rad. 2017-0130- Sentencia No. 068, pág. 31
} 
La sentencia $064^{15}$ del Tribunal Superior del Distrito Judicial de Tunja presenta una problemática que demuestra que en muchas ocasiones se deja de lado el interés superior el NNA y no se acata los preceptuado por las normas internacionales en materia de Protección, las sentencias de primera y segunda instancia resuelven la duda a favor del procesado a pesar que la víctima se halla en estado de incapacidad total razón por la cual no pudo recibirse su testimonio, no obstante los exámenes médicos si demostraron que fue accedida pero por su misma condición no se tuvo la debida diligencia para determinar cuándo pudo haber ocurrido esto, el sindicado por la cercanía pudo haber incurrido en la falta Maxime que la víctima no salió jamás de la esfera del círculo familiar, la discusión para la absolución se centró en la imposibilidad de determinar según los operadores judiciales el momento exacto en que la agresión ocurrió, no obstante estar probado que la víctima si fue abusada se determinó absolver al presunto agresor por el principio del indubio proreo, por encima del principio pro infans que debió prevalecer.

\subsubsection{Debida diligencia por parte de los operadores judiciales al momento de investigar y realizar el proceso judicial.}

Las autoridades judiciales tienen el deber y la obligación de garantizar los derechos fundamentales de los NNA víctimas de ASI, por esta razón los Fiscales deben adelantar las investigaciones pertinentes con gran diligencia, esto incluye realizarlas de forma oportuna sin dilaciones de ninguna naturaleza, permitir a las victimas participar del proceso garantizándoles ser escuchadas y sus testimonios tenidos en cuenta sin que esto vulnere su dignidad y su privacidad, realizar las actuaciones tendientes a la protección de las víctimas para que no se presenten nuevas agresiones, dar aviso oportuno en caso que el agresor sea objeto de alguna medida que lo ponga en libertad.

Punto importante a tener en cuenta es que los operadores judiciales deben armonizar los derechos de los NNA con los demás derechos, sin perder de vista que existe en Colombia la protección de los NNA que permite que los derechos de los mismos primen sobre otros derechos legales.

Por ejemplo, el principio de in dubio pro reo solo debe ser aplicado como resultado de una investigación donde se haya agotado todas las instancias investigativas y no se haya podido demostrar fehacientemente la ocurrencia del hecho.

${ }^{15}$ Tribunal Superior del Distrito Judicial de Tunja, Rad. 2015-0681-01-Sentencia No. 064, pág. 23. 
La debida diligencia también incluye dotar a los NNA de apoyos interdisciplinarios con el fin de atenuar las consecuencias de su participación en el proceso, teniendo siempre de presente que se trata de niños en donde la madurez y su indefensión son factores incidentes importantes aplicando siempre el principio pro infans como criterio hermenéutico.

Dentro del estudio de las sentencias se encontró, fallas debidas a la fiscalía especialmente en el aguo de primera instancia pues no se tuvieron en cuenta en el momento de la acusación factores como los elementos agravantes y las prohibiciones de no otorgarse ningún tipo de beneficio en favor del procesado, además en algunos casos no se realizó eficientemente la investigación correspondiente.

La sentencia 017 de 2019 nos permite ver una serie de errores cometidos por los diferentes operadores judiciales, en desarrollo del proceso judicial; inicialmente ante la denuncia la comisaria de familia impone una medida de amonestación a un agresor sexual ${ }^{16}$, posteriormente en la audiencia de legalización, formulación e imputación, no se le impuso medida de aseguramiento por falta de acreditación de requisitos; tuvo que la fiscalía 18 CAIVAS presentar el escrito de acusación modificando la imputación y adicionándole el concurso homogéneo y sucesivo y la circunstancia de agravación punitiva que no figuraba en la imputación inicial, ya que el fiscal no tuvo en cuenta la condición de la víctima que correspondía a persona en condición de vulnerabilidad por discapacidad Psíquica.

También es importante señalar que a pesar que en el testimonio de una de las víctimas se señaló al procesado como autor del delito de acceso carnal, la fiscalía no pudo probar este cargo y los testimonios de las víctimas no fue tenido en cuenta tanto en la primera como en la segunda instancia de tal manera que solo fue condenado por actos abusivos lo que demuestra los yerros en el proceso investigativo que dio como resultado que el agresor se viera favorecido por un delito menor al que correspondía.

En la sentencia SP 066, el fallador de segunda instancia reprocha a la fiscalía el hecho que no se haya realizado la imputación por el delito de acceso carnal abusivo ${ }^{17}$ dado que se daban los presupuestos del artículo 212 del código penal, y que las victimas señalaron con nitidez y claridad que el procesado penetraba con sus dedos la cavidad anal de las mismas.

\footnotetext{
${ }^{16}$ Tribunal Superior del Distrito Judicial de Tunja, Radicación No. 2018-0186-01, Sentencia 017 de 2019. pág. 2 y131.

17 Tribunal Superior del Distrito Judicial de Tunja, Radicación No. 2015-0777-01 Sentencia 066 de 2017. pág. 61.
} 
Este hecho evidencia el mal proceder de la fiscalía y la falta de la debida diligencia y el conocimiento de las normas jurídicas en la materia.

No debe perderse de vista que la normatividad colombiana no permite hacer más gravosa la situación del procesado razón por la cual así la ley endurezca las penas por estos yerros no se puede dar la aplicación como seria el espíritu del legislador.

La sentencia SP 056 del Tribunal Superior del Distrito Judicial de Tunja, muestra de forma fehaciente como durante el proceso la defensa fue dilatando el juicio y como el operador de primera instancia se equivoca al realizar las valoraciones de todas y cada una de las pruebas, aunque la imputación realizada por la fiscal era correcta el fallador desconoció los obrantes en el proceso y determino una absolución que no resistió el análisis realizado por el fallador de segunda instancia que determino que se encontraba más que probada fuera de toda duda la culpabilidad del procesado y por ende decidió revocar la sentencia absolutoria y proferir la de condena ${ }^{18}$; esto es una clara demostración que la potestad discrecional del juez muchas veces se impone a la normatividad nacional y a las normas internacionales.

En la sentencia No. 64 el Tribunal Superior del Distrito Judicial de Tunja reconoce que pese a la equivocación de la Fiscalía se debió haber sindicado de Acceso carnal en lugar de lesiones al momento de las alegaciones finales, pero como la Facultad punitiva se encuentra en cabeza de Esta corporación no tiene competencia para corregir el yerro. ${ }^{19}$

\subsubsection{5.- Conocimiento de los jueces y magistrados de la normatividad nacional e internacional y la jurisprudencia al momento de valorar los testimonios de las víctimas.}

En su resolución 2005/20, de 22 de julio de 2005, el Consejo Económico y Social aprobó las Directrices sobre la justicia en asuntos concernientes a los niños víctimas y testigos de delitos, estas hacen parte de una serie de normas y reglas de las Naciones unidas en lo concerniente a procesos judiciales.

Además de los derechos ya reseñados y especialmente los mencionados por la Convención sobre los Derechos de los niños, se debe tener en cuenta lo concerniente al trato digno, el acceso a

\footnotetext{
${ }^{18}$ Tribunal Superior del Distrito Judicial de Tunja, Rad. 2017-0965-01- Sentencia No. 0056, pág. 4, 14, 146, 148 y 152 S.s.

${ }^{19}$ Tribunal Superior del Distrito Judicial de Tunja, Rad. 2015-0681-01- sentencia No. 064 de 2016. Pág. 30.
} 
la información, a ser escuchado, a tener una asistencia eficaz, el derecho a su intimidad, a ser protegido durante el proceso judicial, a tener medidas preventivas y a la reparación.

Durante el proceso investigativo y la realización de exámenes los, estándares internacionales recomiendan la presencia de la persona de apoyo, y que si se hace necesario se realice el tratamiento necesario para asegurar la salud de la víctima.

La persona que funja como apoyo será quien represente al NNA, y de las autorizaciones correspondientes al profesional del derecho que lo representara judicialmente, en Colombia este profesional es designado por la Defensoría del pueblo y se denomina Representante Judicial de víctimas.

Respecto a las declaraciones y testimonios del NNA, se considera que ellos son capaces de ser testigos, salvo que se demuestre lo contrario mediante una prueba de incapacidad, de tal manera que su testimonio tendrá validez sin importar su edad siempre y cuando sea capaz de dar el testimonio, la prueba de capacidad debe ser ordenada por el juez o magistrado y se designara un profesional capacitado para que la realice, sin que esta pueda ser repetida nuevamente.

Es necesario que los Juzgados o tribunales tengan un lugar apropiado para la espera del NNA, y no se permitirá bajo ningún concepto que sean accesibles a los acusados o a sus familiares, así mismo el operador judicial dará prioridad a los testimonios de los NNA, sobre los demás testimonios con el fin de que su permanencia sea lo menor posible; es importante que la persona de apoyo designada pueda estar presente y el juez podrá permitirlo.

El juzgado donde se recepcióne la declaración deberá contar con elementos que permitan por ejemplo que un niño en discapacidad pueda estar cómodo, además durante el interrogatorio no se permitirá más que al abogado de la defensa realizar algún tipo de preguntas que puedan ocasionarle angustia o sean intimidantes, y causen sufrimiento en los NNA.

En el análisis de las sentencias se halló que el fallador se segunda instancia basa sus decisiones en la jurisprudencia nacional en donde se reconoce el valor probatorio del testimonio de los NNA.

Por ejemplo, la sentencia SP 016 trae a colación lo preceptuado por la Corte en la sentencia 28742 del 13 de febrero de 2008 
"De acuerdo con investigaciones de innegable carácter científico, se ha establecido que cuando el menor es la víctima de atropellos sexuales su dicho adquiere una especial confiabilidad. Una connotada tratadista en la materia ha señalado en sus estudios lo siguiente:

"Debemos resaltar, que una gran cantidad de investigación científica, basada en evidencia empírica, sustenta la habilidad de los niños/as para brindar testimonio de manera acertada, en el sentido de que, si se les permite contar su propia historia con sus propias palabras y sus propios términos pueden dar testimonios altamente precisos de cosas que han presenciado o experimentado, especialmente si son personalmente significativas o emocionalmente salientes [sic] para ellos. (...)

“...se infiere que el dicho del menor, por la naturaleza del acto y el impacto que genera en su memoria, adquiere gran credibilidad cuando es la víctima de abusos sexuales"

La sentencia SP 01262017-0460 con base en las sentencias de la Corte Suprema de Justicia 13119 del 15/12 /2000, 48231 del 30 /8/2017 y 46165 del 1/7 / de 2017, indica que el valor probatorio de un solo deponente es válido perfectamente para afianzar la certidumbre de una condena de acuerdo con el artículo 373 del Código de Procedimiento Penal

Como puede observarse la jurisprudencia colombiana ha reconocido reiteradamente en sus fallos la importancia de la versión de la víctima y por esto se le debe otorgar una especial confiabilidad, situación que está en armonía con los postulados internacionales pero que en determinadas ocasiones y por el poder discrecional del juez no es tenida en cuenta como debiera hacerse.

\subsubsection{6.- Articulación de las entidades encargadas de la protección de los NNA.}

Tanto la Normatividad internacional como la nacional están de acuerdo que debe existir una cooperación interinstitucional entre las diferentes entidades del Estado para un desempeño eficiente en el proceso de investigación y juzgamiento de un ASI en NNA, esto se traduce por ejemplo que si un fiscal solicita una orden de captura o detención, el juez debe librarlas oportunamente, o se deben poner a disposición dentro de la investigación informaciones que se encuentran en manos de otras entidades como la policía o el ejército, el ICBF o cualquier otra entidad. 
De no existir una colaboración eficaz entre las instituciones se pueden ocasionar demoras y tropiezos que no permitan que el delito sea investigado y judicializado con la celeridad que se requiere en estos casos.

Por esta razón los canales de cooperación deben ser regulados por el Estado ya que es su obligación hacerlo de tal manera que se institucionalice la colaboración y el intercambio de información que permita la realización de las labores de cada operador judicial.

\subsubsection{7.- Aplicación de la normatividad colombiana y la jurisprudencia en el desarrollo del proceso judicial teniendo en cuenta el interés superior de los NNA.}

Para efectuar una correcta aplicación del PRINCIPIO DEL INTERES SUPERIOR DEL NIÑO, ya tratado anteriormente, deben tenerse en cuenta aspectos facticos, como son las circunstancias específicas del caso, siendo este observado en su conjunto; teniendo siempre presente los criterios jurídicos dados por la normatividad y la jurisprudencia para la protección de los NNA

Las autoridades judiciales no pueden descuidar sus deberes constitucionales y legales cuando se trate de proteger a los NNA, lo que implica que deben tener un grado de diligencia mayor al momento de adoptar las decisiones jurídicas correspondientes ya que su decisión afectara en mayor o menor grado el proceso de desarrollo de los NNA.

En la Ley 1098 de Colombia, la violencia sexual contra los NNA, es catalogada como una forma de maltrato infantil, lo que representa un problema pues esto permite que no sea clara la diferencia entre los actos sexuales y los de agresión física o psicológica.

la Ley 1719 de 2014 "Por la cual se modifican algunos artículos de las Leyes 599 de 2000, 906 de 2004 y se adoptan medidas para garantizar el acceso a la justicia de las víctimas de violencia sexual, en especial la violencia sexual con ocasión del conflicto armado", crea nuevos delitos y endurece la pena para los delitos contra la integridad y formación sexual y establece por primera vez obligaciones concretas hacia las víctimas como la reparación la indemnización y la restauración.

La sentencia 025 nos muestra un desconocimiento por parte de la fiscalía y aun del mismo juez del articulo 199 numeral 7 de la ley 1098, al aceptar un preacuerdo con un agresor sexual con 
menor de 14 años pues este prohíbe cualquier tipo de beneficio para el acusado esto en concordancia con la Convención de los Derechos del Niño, y el mismo interés superior de los derechos de los NNA, no obstante en la segunda instancia la mayoría de la motivación se traduce en defender la actuación del fiscal y el juez y a definir congruencia y los principios de taxatividad penal y descuida realmente a la víctima; aunque la sentencia es condenatoria se nota que muchas veces el proceso se desvía del curso para tocar otros aspectos que no existirían si desde el principio de hubiese atendido a la normatividad en materia de protección hacia los NNA víctimas de ASI.

El estudio mostro que a pesar que existen leyes para la protección de los NNA y especialmente los artículos 42 y 44 de la Constitución Nacional lo proclaman, no existe un marco normativo especifico único y exclusivo que aborde la problemática, la ley 1098 que es una de las expresiones de los legisladores para el juzgamiento d estos delitos contra NNA contiene algunos avances significativos en este aspecto, y en su artículo 199 prohíbe cualquier tipo de beneficio para el victimario.

Como ya se expuso anteriormente los jueces al momento de la realización del juicio aun dudan entre aplicar el principio pro infans o el de indubio proreo, y como se evidencio en sentencias ya reseñadas en muchos caso el agresor ha quedado en libertad por que por causas como la dilación del proceso que conllevan a la aplicación de otros derechos del imputado, como los vencimientos de términos, o los errores en la imputación o de hecho la imposibilidad de tener una certeza por el tiempo transcurrido para la realización de los exámenes o de plano por la demora del proceso que puede llegar a ser hasta de 10 años.

Como ya se reseñó también anteriormente, afortunadamente la Jurisprudencia ha ido unificando criterios y ha avanzado en esta problemática conciliando los preceptos internacionales con la normatividad colombiana lo que ha permitido que en algunos casos las victimas tengan voz y representación real, situación que anteriormente se veía menoscabada por el poder discrecional de los jueces para tener en cuenta o no los testimonios de las víctimas. 


\subsubsection{Análisis casos puntuales}

\subsubsection{Caso Tatiana $N$}

\section{CUI 11001600072120120007501}

Tatiana tenía 11 años cuando fue abusada por el compañero sentimental de su progenitora, quien la accedió de forma violenta y la obligó a no decir nada bajo amenaza; ante la situación Tatiana le contó todo a su mamá, pero la reacción de esta no fue de protección hacia Tatiana, pues en lugar de tomar acciones encaminadas a evitar el abuso, le echó la culpa de todo.

Posteriormente la madre de Tatiana abandonó la casa donde residía dejando a su hija a merced del padrastro. A partir de ese momento, Tatiana fue constantemente víctima del abuso por parte de su padrastro, quien la obligó a convivir con él cómo su supuesta compañera y bajo la coerción de haber sido la culpable de la marcha de la madre.

Producto de estas violaciones repetidas Tatiana tuvo 3 hijos con su agresor, quien la maltrataba tanto física como psicológicamente. Cuando Tatiana cumplió la mayoría de edad, decidió abandonar a su padrastro, y denunciarlo por el abuso sexual y las agresiones de las cuales fue víctima por tantos años.

Recibida la denuncia en la comisaría de familia, se inició por parte de esta la constatación de los hechos y se remitió a la Fiscalía, para que se iniciara el proceso judicial correspondiente.

La víctima, una vez interpuesta la denuncia ante la comisaría, recibió un apoyo psicológico inicial por parte de la psicóloga de la entidad para que pudiera afrontar la denuncia y la posterior ratificación ante los estrados judiciales; en ese momento Tatiana contaba ya con 20 años.

En el proceso penal, la defensa planteó que no se trataba de un ASI, sino de un problema de violencia intrafamiliar entre compañeros. Durante la primera instancia, la Fiscalía en conjunto con la Unidad de Víctimas logró hacer prevalecer el derecho de la víctima, al demostrar que el abuso se inició cuando Tatiana contaba con 11 años y por lo tanto así hubiese denunciado siendo y a mayor de edad, esto se enmarcaba en el ASI.

Aunque en primera instancia el agresor fue condenado por abuso sexual agravado por ser la niña menor de 14 años, posteriormente el Tribunal Superior del Distrito Judicial de Tunja absolvió 
al agresor con la teoría de la prescripción por tiempo para realizar la denuncia y la poca credibilidad del testimonio de la víctima.

El operador judicial argumentó que se "trataba de una retaliación por parte de Tatiana para perjudicar al compañero sentimental" y justificar el abandono a este. Actualmente el caso se encuentra en la Corte Suprema de Justicia para casación.

\section{Análisis del caso frente a lo preceptuado por las políticas públicas, los estándares internacionales y nacionales y el proceso judicial}

En el caso en referencia es notorio cómo falla la protección integral de la niña, ya que desde el seno mismo de la familia no se le brinda la atención necesaria y antes, como señalan Vargas, Vargas y Mejía (1997), su palabra es menospreciada y la madre no asume un papel de defensa, sino que, al contrario, contribuye a agravar aún más la situación de la menor al hacerla culpable de la violencia sexual.

Los Mecanismos internacionales contemplados para dar protección y garantizar sus derechos no aparecen por ningún lado, especialmente lo referente al "interés superior del niño", como tampoco aparece la protección, que, según las normas colombianas y especialmente las Leyes 1098 y 1146, deberían habérsele dado a Tatiana.

Fallan los sistemas de protección del ICBF y especialmente falla el operador judicial, al asumir que por continuar viviendo con el agresor y tener hijos con este, subsana el hecho y deja de existir la conducta criminal.

No fue posible aplicar ningún tipo de protocolo de los establecidos, tanto a nivel nacional o internacional, porque la víctima fue sustraída de su entorno social hasta la mayoría de edad, al no permitirle volver al colegio y se ejerció una presión psicológica para que la menor no se relacionara con nadie.

Desafortunadamente el Estado colombiano dentro de su normatividad consagra que la acción penal prescribe en función del tiempo transcurrido, razón por la cual el operador judicial de segunda instancia consideró que ya había operado este fenómeno. 
También se evidenció en este caso, que a pesar de los programas que el Estado ha promulgado, el apoyo psicológico y seguimiento a las víctimas no se realiza integralmente como establece la normatividad, sino que de forma escasa se proporciona un apoyo inicial; por lo tanto, no se aplicó ningún protocolo de los consagrados en las normas y el ICBF.

Fallo la justicia porque, contrario a los tratados internacionales, no se le dio a la víctima la credibilidad que se promulga a pesar de que la jurisprudencia colombiana ha dicho en diversas sentencias, como la T-078/10 del 11 de febrero de 2010, que la víctima goza de la credibilidad y el derecho a presentar pruebas.

Este caso demuestra el desconocimiento flagrante del operador de segunda instancia de la normatividad, y de los tratados internacionales (principio pro infans) al considerar que, por haber existido una convivencia, se subsanaba el abuso sexual, aspecto que desvirtúa la normatividad colombiana y lo preceptuado en los mecanismos internacionales en materia de violencia sexual contra los NNA.

Falla la justicia al no endilgarle responsabilidad penal a la madre y considerar flagrantemente que se trata de una simple denuncia de acceso carnal abusivo, no obstante que el padrastro sometió a la menor y, desde el punto de vista de los estándares internacionales, esto podría catalogarse como matrimonio servil con menor de edad.

Hay una violación del principio de protección dentro del entorno familiar y de los estándares internacionales que prohíben uniones con menores de edad. (Matrimonio servil con menor de edad) y del principio pro infans.

\subsubsection{Caso de Yuri N.}

\section{CUI 15455600011820120007800}

Yuri fue abusada sexualmente por su abuelo paterno, en una ocasión que la niña lo visitó, en una finca de la vereda del municipio de Berbeo (Boyacá). 
Al regreso de la menor del fin de semana, la madre la notó distante y triste; en el colegio su rendimiento empezó a decaer y al observar estos cambios repentinos, la madre le indagó sobre el porqué de sus cambios de comportamiento. Logró que la niña finalmente contara lo sucedido con su abuelo y las amenazas por si llegaba a contar algo.

La madre de Yuri acudió a la comisaría de familia e instauró la denuncia contra el abuelo de la menor. La comisaría comenzó una intervención inmediata, tanto con la niña como con la familia, proveyéndole apoyo psicológico, y envió la denuncia a la Fiscalía, imputó cargos y se inició el proceso judicial con el fin de determinar lo ocurrido.

Se sometió a la menor al protocolo del ICBF, que incluyó la entrevista y la cámara Gesell, en donde en un espacio dividido por un espejo de un lado y con visión desde el otro, se lleva a cabo la entrevista por parte del Psicólogo; además se realizó la valoración por parte de Medicina Legal, llegándose a la certeza del abuso sexual denunciado por la madre.

Iniciado el proceso penal, el agresor fue condenado por "acceso carnal abusivo con menor de 14" años y enviado a la cárcel. Un año después del primer abuso, la madre de Yuri la envió a donde la tía en el casco urbano, para que la ayudara en algunos quehaceres. Al llegar donde la tía, fue recibida por el esposo de esta, quien la abusó sexualmente.

Nuevamente se realizó el procedimiento anteriormente descrito y el agresor fue judicializado y condenado por el delito antes mencionado.

\section{Análisis del caso frente a lo preceptuado por las políticas públicas, los estándares internacionales y nacionales y el proceso judicial}

Aquí se notó la intervención de las instituciones del Estado, tanto de la parte administrativa a través de la comisaría de familia, y de la judicial por medio de la Fiscalía y el juez, además del apoyo de la Defensoría del Pueblo mediante la asignación de un defensor de víctimas.

Se podría decir que en este caso se cumplieron parcialmente los estándares nacionales e internacionales al aplicarse el principio del "interés superior del niño" dentro de la actuación judicial, y dársele la credibilidad debida al "testimonio de la menor víctima".

De igual forma, se ejerció por parte del Estado una labor de protección, al menos en lo que hace referencia a los tiempos del proceso, pues una de las grandes falencias que se le ha criticado al sistema penal colombiano es el tiempo que toma llegar a una decisión judicial final. 
Lo que preocupa en este caso es que se demuestra lo que han venido manifestando los organismos internacionales y el IMLCF; y es que la mayoría de los casos de abuso sexual contra menores ocurre en el entorno familiar y la acción del Estado no incluye la prevención para estas situaciones más allá de la educación y algunas campañas que no son duraderas en el tiempo, sino que son esporádicas.

El programa De Cero a Siempre, que se convirtió en ley de la República, establece una protección integral y un apoyo y seguimiento por parte de las entidades del Estado, especialmente el ICBF, situación que no se denota en el caso ya que la menor fue nuevamente agredida, lo que indica que no hubo seguimiento ni acción por parte del Estado para impedir que la situación se repitiera, como efectivamente ocurrió,

El caso demuestra a las claras que, o bien ha fallado el Estado colombiano en sus políticas de prevención, o que las medidas tomadas en contra de los agresores no surten el efecto esperado por el Estado.

También es evidente que el incremento de las penas por parte de la justicia no disuade a los abusadores y por tal razón las políticas en esta materia no son lo eficaces que debían ser.

No se cumplieron los estándares nacionales ni internacionales en materia para la plena recuperación de la menor víctima y su entorno familiar, hasta su correcta integración social, sin ningún tipo de trauma que no le permita desarrollar una vida plena.

\subsubsection{Caso de actos sexuales contra adolescentes CUI 15455600011820130015900}

Pedro Pablo se desempeñaba como pastor de una comunidad religiosa en Ramiriquí, a donde asistían varias niñas con edades entre los 14 y los 16 años.

Valiéndose de su condición de pastor, lo que le concedía un papel preponderante dentro de la comunidad religiosa, invitaba a su despacho a las jóvenes adolescentes que asistían a los servicios religiosos para, supuestamente, hacer actos de purificación de sus cuerpos.

Una vez las niñas ingresaban al despacho procedía a realizarles tocamientos por todo el cuerpo, especialmente en las partes íntimas y los senos, situación que realizaba en cada oportunidad que las adolescentes asistían a las prácticas religiosas.

Una de las víctimas decidió contar lo que ocurría, y los padres de la menor lo denunciaron ante la Fiscalía. 
Instaurada la denuncia e iniciada la investigación de los hechos, se pudo establecer la veracidad de las afirmaciones de la adolescente; razón por la cual las demás víctimas decidieron unirse a la acción y denunciaron a Pedro Pablo.

El proceso judicial comenzó con estrategias dilatorias por parte de la defensa del imputado y de presiones hacia las víctimas a cargo de la misma comunidad religiosa, para que se retractaran de las acusaciones; por las demoras en el proceso y la mala actuación del operador judicial y con base en la normatividad colombiana, que contempla la posibilidad de la libertad por vencimiento de términos, el acusado fue dejado en libertad. Actualmente el proceso sigue su curso ante la justicia colombiana.

\section{Análisis del caso frente a las políticas públicas, los estándares nacionales e internacionales y el proceso judicial}

Este caso evidencia una situación que es cada vez más recurrente y es el abuso por parte de líderes religiosos. No podemos culpar aquí a las políticas públicas ni al Estado porque las víctimas no pertenecen a un estrato en donde la educación no sea accesible y no se tenga conocimiento de la problemática; por el contrario, pertenecen a grupos con acceso a todo tipo de información y con formación educativa.

Lo que preocupa en este caso es que se demuestra lo que han venido manifestando los organismos internacionales y el Instituto Nacional de Medicina Legal y Ciencias Forenses, y es que la mayoría de los casos de abuso sexual con menores ocurre en un entorno que se considera seguro y por una persona que según su condición debería ser una guía y un protector.

La justicia adelanta el proceso, pero con más tropiezos y dilaciones que avances efectivos, lo que genera desconfianza en la misma comunidad y contribuye a polarizar aún más a los diferentes sectores sociales.

Los operadores judiciales se debaten entre dos situaciones: por un lado, está la cuestión religiosa y por otro la credibilidad de los testimonios. Se denotó en este caso que loso jueces se niegan a aceptar en alguna medida que personas de cierta preponderancia sean victimarios; sin embargo, el material probatorio indica la comisión de la conducta. 
Es claro que el ASI no hace parte de un determinado grupo social, pues según lo demuestra este caso y otros que se han ido conociendo a nivel nacional y regional por reportes de las entidades judiciales y de defensa del ciudadano, este se presenta en todos los sectores sociales sin distinción de estrato social, nivel educativo o grupo étnico o religioso.

Frente al proceso judicial se adelanta el proceso, con más tropiezos y dilaciones que avances efectivos, lo que genera desconfianza en la misma comunidad y contribuye a polarizar aún más a los diferentes sectores sociales.

Se denota la falla en el sistema judicial al no contar el operador con un apoyo que le permita estudiar el caso sin prejuicios ni concepciones de tipo religioso y social. Es en este punto que se hace necesario el grupo interdisciplinario que apoye al juzgador para una justicia real hacia las víctimas. 


\section{CAPÍTULO 4}

\subsection{CONCLUSIONES}

Las conclusiones se dan con base en el estudio realizado en Boyacá y a los análisis específicos de la muestra documental de las 48 sentencias del Tribunal Superior del Distrito Judicial de Tunja en el periodo comprendido entre 2011 hasta 2018 y por lo tanto corresponden a este estudio específico en esta región.

De acuerdo con el estudio realizado se puede concluir que:

Se presentan graves consecuencia por el ASI. Las consecuencias del ASI a corto plazo según la psicología:

No deja de ser significativo que, según las estadísticas de la UNICEF, un porcentaje importante (de quienes fueron objeto de ASI, tiendan a repetir el abuso convirtiéndose de esta manera en abusadores al llegar a la edad adulta. Estudios relacionados con este tema han indicado que el daño sufrido por los niños abusados deja secuelas y en muchos el daño es tan severo que no les permite llevar una vida normal ni tener relaciones sanas.

\subsubsection{Adopción de la normatividad}

El Estado colombiano implementando leyes, decretos y algunas políticas públicas se ha venido ocupando de la problemática de la violencia sexual en los NNA; de igual manera, las altas Cortes han hecho otro tanto a través de la jurisprudencia y el análisis de los casos.

No obstante, lo anterior, si miramos con detenimiento normas como la Ley 1098 de 2006 y demás normas complementarias, los informes de Medicina Legal y las denuncias ante la Fiscalía General de la Nación, se puede concluir que la normatividad existente aun cuando contempla la protección integral de los NNA (Ley 1146) no da los mecanismos necesarios para que esto se cumpla. Por ejemplo, no destina los recursos suficientes, no provee los profesionales necesarios ni 
hace un seguimiento a los programas que se tratan de implementar en materia de educación y prevención.

En cuanto a la normatividad en materia judicial, esta necesariamente se enfoca en la sanción, endureciendo las penas como único mecanismo para tratar que el abuso cese o al menos disminuya, pero ni así este se reduce; antes, por el contrario, y de acuerdo con los reportes de las entidades del Estado, ha ido en aumento.

En Boyacá según lo demuestra el estudio se da la situación que se describe a nivel nacional, por que obviamente la normatividad es una sola y las leyes se aplican en todo el territorio nacional, y en cuanto a la protección de integral de los NNA tampoco en el departamento se dan los mecanismos para que esta sea efectiva, ni se cuenta con los recursos necesarios para la implementación de los programas de educación y prevención

\subsubsection{Dificultad de la denuncia de situaciones en los hogares}

Cuando un NNA es abusado dentro de su propio entorno familiar la afectación Psicológica que puede llegar a sufrir es muy grande Maxime si el agresor es el padre o la madre o un familiar muy cercano. Las afectaciones en el futuro pueden llegar a ser mayores. Las consecuencias a largo plazo pueden ser así mismo mayores o menores dependiendo tanto del apoyo que reciba la victima como de su desarrollo psicológico, no obstante, se ha demostrado que existe una relación importante entre los comportamientos sexuales en la edad adulta y el abuso sufrido en la infancia o adolescencia. (Manual de Psicología 2001).

La legislación vigente presenta conflicto en cuanto al abuso sexual, porque dentro del entorno familiar el Estado no tiene cómo controlar lo que ocurre dentro de los hogares y además las situaciones no se denuncian, no se judicializan y las víctimas no son protegidas.

Un ejemplo de lo anterior lo encontramos en la Ley 906 de 2004, que establece el deber de denunciar según el artículo 67 pero en el artículo siguiente indica que si quien conoce el delito tiene algún vínculo de parentesco con el agresor esta exonerado de ese deber, es decir en los casos de abuso intrafamiliar no existe la obligación de denunciar lo que permite que el agresor coaccione a los miembros del entorno familiar para guardar silencio y continuar con el abuso.

Es preocupante que la mayoría de los casos del ASI ocurran en entornos familiares. De acuerdo con estudios y reportes, el victimario en un alto porcentaje, cerca del $90 \%$ es alguien del 
entorno familiar primario tíos, primos, padrastros padres o a personas muy cercanas por lazos de amistad o quien este responsable del cuidado de los niños (casos hogares de bienestar) (INMLCF, 2012).

El estudio evidencio que en Boyacá esta problemática de la inseguridad en el entorno familiar esta presente y tiene un alto índice de ocurrencia, como se puede ver en los casos puntuales arriba mencionados y en algunas de las sentencias objeto de análisis.

\subsubsection{No se implementa la protección superior del niño}

Según las nuevas tendencias jurisprudenciales contenidas en sentencias. 80488- 2015, STP84422015, 85216- 2016 y STP4883-2016, no se prohíbe de forma legal a los jueces de control de garantías; dar a los acusados de ASI y que estén detenidos preventivamente la libertad provisional si se han vencido los términos legales del articulo 317-4 del CPP.

Entonces se colige que los victimarios gozan de la protección de la norma y pueden recobrar su libertad con frecuencia, especialmente por vencimiento de términos.

Boyacá respecto a este tópico no ha sido ajena y la situación se ha presentado especialmente por la demora de los entes encargados de dinamizar el proceso pues en casos que actualmente se siguen algunos acusados han recobrado su libertad por vencimiento de términos, o en algunos casos han sido enviados a su casa con la consecuente afectación hacia la víctima.

\subsubsection{Existe violencia sexual infantil}

Colombia, en su normatividad ha consagrado que la edad mínima para tener relaciones sexuales consentidas es de 14, de tal manera que se considera ASI una relación con menor de esa edad así esta sea consentida por la víctima.

Cuando el abusador se encuentra en el rango de edad entre los 14 y los 18 años y la víctima es menor de 14 años, la ley considera que tiene responsabilidad penal si tiene relaciones sexuales con ella así sean de igual forma consentidas.

Acorde con los casos estudiados y que se encuentran en los procesos de las sentencias el

fenómeno de la violencia sexual contra NNA, ha sido una problemática en Boyacá a través de los 
tiempos, y ha estado presente por la misma formación cultural del Boyacense, pues en esta región como en muchas culturas, no se le da a los NNA la importancia debida siendo considerado en la gran mayoría de los casos como poco significativo, por la misma subvaloración frente al padre que tiene el resto de la familia.

El estudio en el departamento demostró que el ASI, no es exclusivo de una clase social ni de un estrato determinado, los abusadores se encuentran en cualquier nivel social, muchas veces disfrazados de personas aparentemente correctas, además lo más grave es que el abusador se vale de medios de coerción para que la víctima no lo denuncie o inclusive lo presenta ante los niños como una cosa normal.

Preocupa mucho el hecho que a pesar de todos los esfuerzos a nivel mundial aún se siga presentando el ASI, y que la tendencia en vez de disminuir pareciera ir en aumento Maxime que cada día se conocen mayor cantidad de casos en donde las víctimas son niños y niñas entre 5 y 9 años.

Esta situación se hace palpable en el estudio en donde se evidencia que en el departamento de Boyacá las cifras tienden a aumentar y la violencia sexual hacia los NNA, es cada vez mas repetitiva sin que los esfuerzos tanto nacionales como internacionales o departamentales surtan un efecto reversible del problema.

\subsubsection{El Estado colombiano y el departamento de Boyacá refuerza su lucha contra esta problemática}

El Estado se ha venido ocupando de la problemática del ASI instituyendo reforzando la legislación con la expedición de nuevas y decretos y con programas de política pública; otro tanto realiza las altas Cortes ajustando y unificando la jurisprudencia, de igual manera el departamento a través de las mesas de trabajo y en coordinación con el ICBF y la Fiscalía, realizan labores tanto de prevención como de persecución de este delito.

\subsubsection{Se presenta desarticulación de las entidades públicas involucradas}

De acuerdo con las políticas de para la protección de los NNA, en materia de prevención, la normatividad obliga de manera urgente integrar los órganos de atención a la infancia y a la familia, 
las redes de apoyo y las mesas de trabajo para atención de niñez y adolescencia, así como a poner en funcionamiento todos los modelos establecidos para este fin.

No obstante, en la práctica las entidades terminan trabajando de manera independiente ya sea porque no se crean los espacios necesarios para la interacción o, como en el caso de municipios lejanos, porque la ayuda estatal no llega nunca para implementar la logística y en el caso de Boyacá la distribución de recursos no es suficiente y escasamente en las grandes ciudades se tienen algunos apoyos entre las entidades en el sector rural, cada entidad trata de valerse por sí misma.

Un claro ejemplo lo constituye que aunque existen diferentes protocolos para brindarle la atención a las víctimas de abuso o únicamente hay un protocolo denominado "Modelo de Intervención Integral en casos de abuso sexual infantil" (Ministerio de la Proteccion Social Colombia, 2011), en el cual se contemplan una serie de acciones por ser realizadas, pero que en Boyacá nunca se llevan a cabo porque no se cuenta con los recursos necesarios; por tanto, la atención se reduce a la denuncia y al acompañamiento en la fase inicial por parte de la comisaría de familia y el ICBF.

En cuanto al proceso judicial, como se evidencia en las sentencias bases del estudio en Boyacá no existen realmente grupos interdisciplinarios especializados que incluyan psicólogos o trabajadores sociales que permitan que el operador judicial cuente con herramientas de apoyo para que los jueces o magistrados puedan tomar una decisión más justa para las víctimas de la agresión y no terminen favoreciendo al agresor.

Entonces, así se promulguen más leyes o se endurezcan las penas, nada de esto será suficientemente efectivo, hasta tanto el Estado no invierta recursos para la prevención del ASI y en la formación de los operadores judiciales que permita que sus decisiones favorezcan a la víctima y no al victimario.

Además, es urgente incorporar en la preparación académica y a nivel ciudadano la formación en derechos humanos y establecer políticas públicas en el sentido de la prevención y atención a los menores, pero que no se queden únicamente en el papel y las buenas intenciones, y por el contrario permitan un manejo preventivo más que sancionatorio esto aplicable no solo en Boyacá sino a nivel nacional.

A pesar de que Colombia ha adoptado los acuerdos y tratados internacionales en materia de protección de los NNA, el país apenas ha hecho avances limitados en esos compromisos. 
Lo anterior, ya que en las políticas de protección a los menores hay un cuello de botella en la implementación judicial y en la aplicación por parte de los operadores jurídicos de estos sistemas de protección de los menores.

\subsubsection{No se reducen los casos, solo se aumentan las penas}

Esto se deduce al examinar las cifras, los datos y los indicadores de infancia en Colombia. Al hacer una comparación entre la situación de ayer con la de hoy solo se encuentran avances en el incremento de las penas, pero no una reducción significativa en los casos de ASI; prueba de lo anterior lo constituyen las leyes 599 de 2000 o Código Penal, 1236 de 2008 que modifico lo relativo a delitos de abuso sexual, y la 1146 de 2007 que contempla normas para prevenir la violencia sexual y cobija la atención integral de los NNA abusados sexualmente.

Con respecto al tema de la rehabilitación y resocialización de los niños víctimas es preocupante ver que no se encuentra bien definido, e inclusive los protocolos del ICBF no son suficientes para que los NNA objeto de ASI, reciban la atención estipulada tanto en los convenios internacionales como por la normativa interna.

De acuerdo con la legislación nacional e internacional se debe propender por evitar la revictimización (Rochel, 2005), (Palomero, 2007), (UNICEF, 2009) y garantizarse los derechos de los NNA (ICBF, 2007). Sin embargo, en los estrados judiciales estos preceptos no se cumplen y por ejemplo un proceso judicial conlleva años en los cuales la víctima no puede olvidar la agresión porque siempre está expuesta por ser parte del proceso.

Consideramos que en Boyacá hay un fracaso de las políticas públicas frente a la reducción del abuso. Según el gobierno colombiano, en los lineamientos de políticas públicas para la infancia establece que estas se vienen desarrollando en pro de la infancia y su protección tienen como "objetivo que las instituciones que se encarguen del bienestar de la niñez y la familia sean sostenibles, permanezcan en el tiempo y cumplan con la función para la cual fueron creadas para poder cumplir con el fin primordial del Estado de proteger a los NNA"; de la misma manera el Estado debe proveer los recursos necesarios para cumplir este propósito, situación que en el departamento no se da de forma real.

No obstante, es claro que el Estado y el departamento ha fracasado en estos propósitos, pues quienes han realizado grandes esfuerzos en el sentido de dar apoyo a las víctimas han sido las Comisarias de familia inicialmente; con el apoyo posterior un tanto exiguo del ICBF, la ayuda del 
Gobierno nacional ha sido pues casi nula, a pesar de que existen protocolos y rutas de atención que no funcionan por falta de la destinación de recursos para la financiación de estos sectores.

\subsubsection{Se tienen fallas en la parte preventiva y de protección contra el ASI}

No se tiene en el departamento de Boyacá un verdadero enfoque en el tema de la prevención, porque a pesar que el gobierno ha invertido en programas y en foros de infancia la realidad es que no se destinan los recursos suficientes para prevenir proteger y atender los NNA víctimas de ASI; lo que finalmente hace que solo existan en el papel los programas y proyectos de atención y protección; si bien es cierto que el Estado ha expedido nuevas leyes y decretos estos están encaminados a una actuación posterior al abuso lo que los hace ineficaces en la prevención del delito de ASI.

Otra falla en la prevención es que no se cuenta en el Departamento con un programa educacional concreto encaminado a enseñar a los NNA a reconocer situaciones que los coloquen en riesgo, pues los colegios no cuentan con una catedra en donde se les explique a los menores en que consiste el ASI y como deben actuar en caso de ser molestados en su intimidad.

\subsubsection{Faltan redes de apoyo para los jueces y magistrados}

En cuanto al proceso judicial, no existen en Boyacá grupos interdisciplinarios especializados que incluyan psicólogos y trabajadores sociales que permitan que el operador judicial cuente con herramientas de apoyo en el tema de abuso y violencia sexual y que le posibiliten tomar una decisión más justa para las víctimas de la agresión.

El departamento, por otra parte, tampoco contempla un programa que tenga como objetivo capacitar a todos y cada uno de los operadores judiciales que intervengan en el proceso judicial, para su sensibilización y conocimiento de la temática real del problema.

\subsubsection{En Colombia y Boyacá se lucha contra el ASI a través de la normatividad y la jurisprudencia}

Desde la promulgación de la nueva Constitución Política de Colombia, y la ratificación por el Estado Colombiano de la CDN, Colombia avanza hacia un cambio en los esquemas sociales, culturales y políticos y entra en la era de la llamada "Doctrina de la protección integral” (Buaiz, 2003).

A partir de ahí las normas colombianas comienzan un proceso de ajuste con el fin de modificar la normatividad y hacerla más acorde con la problemática de abuso y violencia sexual 
que se está presentado; así se tipifica el delito en el Código Penal y se endurecen las penas para los agresores. Igualmente se impone la protección reforzada al menor y se pone de manifiesto el interés superior del niño, acorde con los tratados internacionales y especialmente la Convención de los Derechos del Niño.

Referente a los casos, el análisis de estos demuestra que en Boyacá se presentan dificultades para poder aplicar los estándares de protección a los NNA, tanto los internacionales como los nacionales, al momento de ser judicializados los casos de abuso y violencia sexual contra los NNA.

En los casos referenciados es notorio cómo falla el Estado en dar la adecuada protección a las víctimas, pues ni este, nial interior de la familia se brinda la atención necesaria y, antes, como señalan Vargas, Vargas y Mejía (1997), en muchos casos su palabra es menospreciada y esto contribuye a agravar aún más la situación de la víctima al hacerla sentir culpable del abuso y la violencia sexual.

Los Mecanismos de protección integrados a la normatividad interior y contemplados en la Convención para la Protección del Niño y sus protocolos no aparecen por ningún lado en el departamento, como tampoco la protección que, según las normas colombianas y especialmente la Ley 1098, debería habérsele dado a las víctimas.

\subsubsection{Falta de aplicación del interés superior del niño}

Desafortunadamente Colombia dentro de la normatividad establece que en la acción penal prescribe por el transcurso del tiempo, con base en esta norma los jueces se ven en muchos casos avocados a decretar la operación de este fenómeno lo que hace que las víctimas del injusto pierdan su derecho a tener justicia y a ser reparados por este hecho.

También se evidenció en los casos, que a pesar de los programas que el Estado ha promulgado, en Boyacá el apoyo psicológico y seguimiento a las víctimas, contemplado en los estándares internacionales, no se realiza integralmente como establece la normatividad, tanto nacional como internacional, sino que escasamente se proporciona un apoyo inicial, vulnerándose de esta manera los preceptuado por las normas nacionales y los protocolos y convenciones respecto al interés superior del niño como precepto prioritario. 


\subsubsection{El aumento de las penas no disuade al agresor}

Es evidente según lo demostró el estudio que el incremento de las penas por parte de la justicia no disuade a los abusadores y por tal razón las políticas en esta materia no son lo eficaces que debían ser. En los casos se pone de presente que, por ejemplo, se produjo una nueva agresión a pesar de que un miembro de la familia estaba en proceso de judicialización por un hecho similar.

\subsubsection{Existe incumplimiento de los estándares de protección al menor}

En materia de atención a la víctima en el departamento no se cumplen los estándares nacionales ni internacionales que establecen la "ayuda en la recuperación de la menor víctima hasta su correcta integración social", sin ningún tipo de trauma que no le permita desarrollar una vida plena, pues como se evidencia en el estudio las victimas nunca reciben seguimiento ni ayuda terapéutica alguna posterior al hecho.

\subsubsection{Se presenta preponderancia del proceso judicial sobre los derechos de la víctima}

La normatividad colombiana pone énfasis en el proceso judicial y el castigo de los agresores, pero no tiene un sistema que permita que la declaración de la víctima tenga el valor probatorio que amerita, y en la mayor parte de los casos se desecha la declaración de víctima porque aún hoy en día los jueces y fiscales consideran al menor inmaduro y su credibilidad es muy cuestionada, tal como se evidencia en los casos mostrados.

Aunque Colombia ha suscrito los acuerdos internacionales y ha incorporado a su normatividad los diferentes protocolos internacionales y ha tratado de desarrollar políticas encaminadas a la prevención y atención de las víctimas, es claro que existen fallas dentro de la aplicación de estas en el país y en el departamento pues como se demuestra con los casos abordados, la falencia judicial y de la interpretación de las normas ha permitido en muchos casos que los niños sigan siendo víctimas inermes en manos de los adultos agresores.

Así mismo se encontró en el estudio que existen diversos factores que permiten que el ASI se de en Boyacá, entre estos se destacan la falta de una logística que permita la aplicación de los mecanismos internacionales y nacionales para hacer la prevención, y la inaplicabilidad de las políticas de Estado, que no cuentan con un medio eficaz para la prevención y atención de las menores víctimas. 
Por otra parte, el estudio demostró que la falta de una educación en materia sexual tanto para los niños como para las familias permite que en algunos casos los padres abusen de sus hijos con la convicción de que está permitido hacerlo, dado que desconocen los derechos que en esta materia les asisten a los niños como poseedores de derechos.

También este estudio demostró como factores socioeconómicos son caldo de cultivo para que se continúe presentando el abuso y la violencia sexual contra los NNA, ya que el hacinamiento habitacional, los escases de recursos y el no contar con una estabilidad económica permiten que los hogares sean disfuncionales y el padre en muchas ocasiones sea el único proveedor, lo que lo lleva a realizar actos reprobables, con la amenaza de no seguir proveyendo lo necesario.

Pareciera que a pesar de todo lo que ha hecho el Gobierno y la gobernación de Boyacá a través de campañas y de endurecimiento de penas, no ha servido para nada, pues según los informes de Medicina Legal y diferentes ONG, cada día se abusa más de los niños, tanto en Boyacá como en el resto del país.

\subsubsection{Colombia y Boyacá han avanzado en su camino de proteger a los NNA}

El estudio demostró que realmente que Colombia ha avanzado en su legislación sobre la protección de los NNA al implementar los estándares internacionales, es una realidad, pero que las "políticas públicas de infancia y adolescencia" no han desarrollado una efectiva acción de protección eficaz en Boyacá en los casos del ASI y violencia sexual, ni los programas de prevención han evitado la ocurrencia, y falta que las políticas públicas se centren más en la prevención y no solo en el castigo, porque es un hecho comprobado que el endurecimiento de las penas no ha sido la solución para resolver la problemática del abuso sexual contra los NNA.

\subsection{RECOMENDACIONES}

Para que se pueda detener el abuso y la violencia sexual contra los NNA:

Se hace necesario revisar y fortalecer los programas orientados a la protección integral de los NNA, involucrando a todos los sectores del país, tanto institucionales como organizaciones del sector privado, para que trabajando mancomunadamente se pueda lograr la erradicación del ASI. 
Para que tanto los esfuerzos mundiales y nacionales sean efectivos para prevenir el abuso y la violencia sexual a los NNA, se requiere que los países, en especial algunos en Latinoamérica, implementen dentro de sus legislaciones los estándares internacionales en materia de protección a los NNA y se incluyan en los programas de gobierno los presupuestos necesarios para que los planes y programas destinados a prevenir el abuso puedan realizarse y cumplir con el objetivo con que se creen.

\subsubsection{En cuanto a la falta educación y prevención}

Es importante la educación para lograr un proceso efectivo dentro del marco de la prevención, ya que esta tiene un papel preponderante; sin embargo, se hace necesario cambiar los viejos esquemas tradicionales de formación, incluyéndose la cátedra de sexualidad con énfasis en la prevención, involucrando a los padres por medio de talleres que permitan orientar tanto a los menores como a los padres en los riesgos de ser víctimas del ASI y la violencia sexual, y educar de forma articulada a través de organismos públicos con mayores responsabilidades para formar en este sentido. Se destacan la Policía Nacional, la Fiscalía, la Procuraduría y las instituciones educativas.

\subsubsection{Respecto a los fracasos de las políticas públicas}

Se deben establecer acciones, planes y programas específicos orientados al ASI porque actualmente se tienen políticas de infancia y adolescencia, pero no existe un programa específico para la prevención, el seguimiento, la atención y recuperación de los niños abusados. Se deben articular todas las instituciones gubernamentales para que así se logre dar la protección y atención a los NNA víctimas de ASI.

Es vital y fundamental que la justicia colombiana tenga una clara definición de los estándares nacionales e internacionales al momento del impartir justicia. El sistema judicial debe contar con un programa encaminado a capacitar a los operadores judiciales (jueces, fiscales, peritos, policía judicial, psicólogos e investigadores), pero no solo en lo relativo a la aplicación de penas y el reforzamiento del sistema penitenciario, sino que tengan una formación en los derechos de los NNA y especialmente en el derecho prevalente de los menores de edad.

Cualquier acción, plan o programa debe estar orientado a un solo objetivo y es la acción decidida y frontal de todos y cada uno de componentes de la sociedad, para la protección de los 
niños, involucrándose todos en una verdadera cruzada de prevención, que debe ser la prioridad para lograr proteger a los NNA de forma efectiva.

Se impone entonces que Colombia cumpla cabalmente con todo lo incluido en los tratados internacionales que ha ratificado e incorporado a su normatividad interna, lo que significa que no basta con adecuar la legislación nacional, sino que debe prestar atención en que se cumplan los derechos de los NNA, se protejan de acuerdo con lo establecido y se incluya a todos los sectores sociales y gubernamentales en este propósito.

Se requiere así mismo que las Cortes que han trabajado en el aspecto del ASI en Colombia continúen unificando la jurisprudencia a ese respecto y que, en general, esos cambios jurisprudenciales de las diferentes Cortes y especialmente de la Corte Suprema de Justicia sean tenidos en cuenta por los falladores al momento de emitir una sentencia.

Se hace indispensable además de urgente desarrollar toda la política social en torno de los derechos de los niños y dar aplicación a la normatividad existente desde un punto coherente y coordinado con todos los estamentos del Estado.

Más que imponer penas, se necesitan campañas de concientización y visibilización de esta problemática que está siendo sepultada en medio de normas y de tratados que finalmente no llegan al punto neurálgico y es la protección real e integral de los NNA.

\section{REFERENCIAS}

Abril, V. (2016). Abuso Sexual Infantil: Protocolos de Proteccion Integral en Colombia. (Tesis de Grado). Pontificia Universidad Javeriana, Bogota. 
Abril, V. (2016). Abuso Sexual Infantil: Protocolos de Proteccion Integral en Colombia. (Tesis de grado en Psicologia). Pontificia Universidad Javeriana, Bogota.

Abril, V. (s.f.). Abuso Sexual Infantil : Protocolos de Proteccion Integral en Colombia. Pontificia Universis.

Alberto, R. L. (enero- junio de 2003). www.redalcy.org. Obtenido de http://www.redalyc.org/articulo.oa?id=64720108

Asociacion de mujeres para la salud. (s.f.). mujeres para la salud.org. Obtenido de https://www.mujeresparalasalud.org/spip/IMG/pdf/folletoincesto.pdf

Ardila, C. y Valencia, O. (1999). Un enemigo conocido: abuso sexual en el hogar y como arma de guerra. Bogotá: Cedavida.

Barudy, J. (1998). El dolor invisible de la infancia. Una lectura ecosistémica del maltrato infantil. Madrid: Paidós. Recuperado de https://bauldelibroses.files.wordpress.com/2016/02/eldolor-invisible-de-la-infancia-jorge-barudy.pdf

Barudy, J. (2011). La responsabilidad del mundo adulto en la producción del sufrimiento infantil. Programa de reparación médico-psicosocial para víctimas de la violación de los derechos humanos. Recuperado de http://paicabi.cl/web/wpcontent/files_mf/1361218157responsabilidad_mundo_adulto.pdf

Beloff, M. (2014). Protección a la niñez en América Latina. Fortalezas y debilidades, Monterrey. Coordinación Editorial del Poder Judicial de Nuevo León. Recuperado de http://www.pjenl.gob.mx/cj/Publicaciones/30.pdf.

Beloff, M. (2014). www,derecho.ubar.ar. Obtenido de www.derecho.uba.ar/publicaciones/lye/revistas/89/beloff-mary-a-la-proteccion-de-losninos-y-las-politicas-de-la-diferencia.pdf.

Berenstein, I. (2007). Del ser al hacer. Buenos Aires: Paidós. Recuperado de http://cepsifotocopiadora.com.ar/archivos/folios/35647_2015825.pdf 
Berlinerblau, V. y Taylor, E. (2003). Abuso sexual: evaluación psiquiátrica forense en denuncias de niños. Cuadernos de Medicina Forense, 2, 33-42. Recuperado de http://www.medicinaforenseperu.org/media/documentos/20100216161208.pdf

Cilleros, M. (s. f.). Infancia autonomía y derechos: una cuestión de principios. Instituto Interamericano del niño, niña y adolescente. Recuperado de http://www.iin.oea.org/Cursos_a_distancia/explotacion_sexual/Lectura4.Infancia.DD.pdf

CIDH. (octubre de 1998). www.oas.org. Obtenido de www.oas.org/es/cidh/infancia

CIDH. (s.f.). www.cidh.oas.org. Obtenido de

https://www.cidh.oas.org/Basicos/Spanish/Basicos2.htm.

Congreso de la Republica de Colombia, Constitucion Politica. (20 de julio de 1991).

www.secretariasenado.gov.co. Obtenido

de

www.secretariasenado.gov.co/senado/basedoc/constitucion_politica_1991.html

Congreso de la Republica de Colombia. (24 de febrero de 1947). www.icbf.gov.co. Obtenido de https://www.icbf.gov.co/cargues/avance/docs/ley_0083_1946.htm

Congreso de la Republica de Colombia. (20 de julio de 1991). Obtenido de wsp.presidencia.gov.co/Normativa/Documents/Constitucion-Politica-Colombia.pdf

Congreso de la Republica de Colombia. (22 de enero de 1991). www.lexbase.co. Obtenido de https://www.lexbase.co/lexdocs/indice/1991/10012de1991 
Congreso de la republica de Colombia. (20 de julio de 1991). www.secretariasenado.gov.co. Obtenido www.secretariasenado.gov.co/senado/basedoc/constitucion_politica_1991.html

Congreso de la republica de Colombia. (4 de agosto de 2001). www.secretariasenado.gov.co. Obtenido de www.secretariasenado.gov.co/senado/basedoc/ley_0679_2001.html

Congreso de la republica de Colombia, 1989,Decreto2737. (1989). www.oas.org. Obtenido de https://www.oas.org/dil/esp/Decreto_2737_de_1989_Colombia.pdf

Congreso de la Republica de Colombia, 2001, Ley 679. (2001). www.secretariasenado.gov.co. Obtenido de www.secretariasenado.gov.co/senado/basedoc/ley_0679_2001.html

Congreso de la Republica de Colombia, Codigo Penal. (24 de julio de 2000). www.secretariasenado.gov.co. Obtenido de www.secretariasenado.gov.co/senado/basedoc/ley_0599_2000.html

Congreso de la Republica de Colombia, Ley 1098 de 2006. (8 de noviembre de 2006). www.icbf.gov.co. Obtenido de https://www.icbf.gov.co/cargues/avance/docs/ley_1098_2006.htm.

Congreso de la Republica de Colombia, Ley 1146. (2007). Diario oficial de la republica de Colombia. Bogota, Colombia. 
Congreso de la Republica de Colombia, Ley 1146. (10 de julio de 2007). www.ramajudicial.gov.co. Obtenido

https://www.ramajudicial.gov.co/documents/573203/887553/Ley+1146+de+2007+\%28Pre vención+violencia+sexual+de+los+niños+y+adolescentes\%29.pdf/3a258443-d17e-4bc79d04-5a4d04980e18.

Congreso de la República de Colombia. (1887). Código Civil Ley 57, con arreglo al artículo 52 de la Constitución de la República. Bogotá. Avance Jurídico Casa Editorial Ltda.

Congreso de la República de Colombia. (1946). Ley 83 de 1946 derogada por el artículo 353 del Decreto 2737 de 1989 por el cual se expide el Código del Menor. Bogotá, Colombia: Diario Oficial 39.080 del 27 de noviembre de 1989.

Congreso de la República de Colombia. (1979). Ley 7 de 1979 modificada por la Ley 1607 de 2012, por la cual se expiden normas en materia tributaria y se dictan otras disposiciones. Bogotá, Colombia: Diario Oficial 48.655 del 26 de diciembre de 2012.

Congreso de la República de Colombia. (1991). Código de Procedimiento Penal, Decreto 2700 de 1991. Derogado por la Ley 600 de 2000. Bogotá, Colombia: Diario Oficial 40.190 del 30 de noviembre de 1991.

Congreso de la República de Colombia. (1991). Constitución Política de Colombia. Esta versión corresponde a la segunda edición corregida de la Constitución Política de Colombia, publicada en la Gaceta Constitucional 116 de 20 de julio de 1991. Recuperado de http://www.secretariasenado.gov.co/index.php/constitucion-politica

Congreso de la República de Colombia. (2000). Código de Procedimiento Penal, Ley 600 de 2000. Bogotá, Colombia: Diario Oficial 44.097 del 24 de julio de 2000. 
Congreso de la República de Colombia. (2001). Ley 679 de 2001 por medio de la cual se expide un estatuto para prevenir y contrarrestar la explotación, la pornografía y el turismo sexual con menores, en desarrollo del artículo 44 de la Constitución. Bogotá, Colombia: Diario Oficial 44.509 del 4 de agosto de 2001.

Congreso de la República de Colombia. (27 de diciembre de 2002). Ley 789 de 2002 por la cual se dictan normas para apoyar el empleo y ampliar la protección social y se modifican algunos artículos del Código Sustantivo de Trabajo. Bogotá, Colombia: Diario Oficial 45.046.

Congreso de la República de Colombia. (8 de noviembre de 2006). Ley 1098 mediante la cual se expide el Código de Infancia y Adolescencia. Bogotá, Colombia: Diario Oficial 46.446.

Congreso de la República de Colombia. (10 de julio de 2007). Ley 1146 por medio de la cual se expiden normas para la prevención de la violencia sexual y atención integral de los niños, niñas y adolescentes abusados sexualmente. Bogotá, Colombia: Diario Oficial 46.685.

Congreso de la República de Colombia. (2008). Ley 1236 de 2008 por medio de la cual se modifican algunos artículos del Código Penal relativos a delitos de abuso sexual. Bogotá, Colombia: Diario Oficial 47.059 del 23 de julio de 2008. Recuperado de http://www.funcionpublica.gov.co/eva/gestornormativo/norma.php?i=31612

Congreso de la República de Colombia. (2011). Ley 1453 de 2011 por medio de la cual se reforma el Código Penal, el Código de Procedimiento Penal, el Código de Infancia y Adolescencia, las reglas sobre extinción de dominio y se dictan otras disposiciones en materia de seguridad. Bogotá, Colombia: Diario Oficial 48.110 del 24 de junio de 2011.

Congreso de la República de Colombia. (2013). Ley 1620 de 2013 por la cual se crea el Sistema Nacional de Convivencia Escolar y Formación para el Ejercicio de los Derechos Humanos, la Educación para la Sexualidad y la Prevención y Mitigación de la Violencia Escolar. Bogotá, Colombia: Diario Oficial 48.733 de 15 de marzo de 2013. Recuperado de https://www.icbf.gov.co/cargues/avance/docs/ley_1620_2013.htm 
Consejo Nacional de politica Economica. (3 de diciembre de 2007). Documento Conpes Social. Bogota, Colombia.

Consejo Nacional de Política Económica Social . (3 de diciembre de 2007). https://www.mineducacion.gov.co. Obtenido de https://www.mineducacion.gov.co/1759/articles-177832_archivo_pdf_Conpes_109.pdf

Consejo Nacional de Politica Economica, Departamento de planeacion, Republica de Colombia. (3 de diciembre de 2007). www.mineducacion.gov.co. Obtenido de https://www.mineducacion.gov.co/1759/articles-177832_archivo_pdf_Conpes_109.pdf

Contreras, J. M., Bott, S., Guedes, A. y Dartnall, E. (2010). Violencia sexual en Latinoamérica y el Caribe: análisis de datos secundarios. Iniciativa de Investigación sobre la Violencia Sexual. Recuperado de http://www.oas.org/dsp/documentos/Observatorio/violencia_sexual_la_y_caribe_2.pdf

Corbin, J. y Strauss, A. (2002). Bases de la investigación cualitativa. Técnicas y procedimientos para desarrollar la teoría fundamentada. Medellín: Universidad de Antioquia.

Corte Constitucional. (8 de noviembre de 2011). Sentencia T-843. [MP Jorge Ignacio Pretelt Chaljub]. Recuperado de http://www.corteconstitucional.gov.co/relatoria/2011/T-84311.htm

Corte Constitucional. (22 de noviembre de 2011). Sentencia C-876. [MP Mauricio Gonzales Cuervo]. Recuperado de http://www.corteconstitucional.gov.co/RELATORIA/2011/C-87611.htm

Corte Constitucional. (15 de diciembre de 2011). Sentencia T-973. [MP Gabriel Eduardo Mendoza]. Recuperado de http://www.corteconstitucional.gov.co/relatoria/2011/T-973-11.htm 
Corte Constitucional. (7 de marzo de 2013). Sentencia T-117. [MP Alexei Julio Estrada]. Recuperado de http://www.corteconstitucional.gov.co/relatoria/2013/T-117-13.htm

Corte Constitucional. (24 de febrero de 2016). Sentencia C-085. [MP Jorge Ignacio Pretelt Chaljub]. Recuperado de http://www.corteconstitucional.gov.co/relatoria/2016/C-085-16.htm

Corte Constitucional de Colombia, Sentencia T- 078. (11 de febrero de 2010). www.corteconstitucional.gov.co. Obtenido de www.corteconstitucional.gov.co/relatoria/2010/T-078-10.htm

Corte Constitucional de Colombia, Sentencia T -117/13. (2013). www.corteconstitucional.gov.co. Obtenido de http://www.corteconstitucional.gov.co/relatoria/2013/T-117-13.htm

Corte Constitucional Republica de Colombia, Sentencia T- 973. (15 de diciembre de 2011). www.corteconstitucional.gov.co. Obtenido de www.corteconstitucional.gov.co/relatoria/2011/T-973-11.htm.

Corte Constitucional, Sentencia C- 876. (22 de noviembre de 2011). www.corteconstitucional.gov.co. Obtenido de www.corteconstitucional.gov.co/RELATORIA/2011/C-876-11.htm

Corte Constitucional, Sentencia T-843. (2011). www.corteconstitucional.gov.co. Obtenido de www.corteconstitucional.gov.co/relatoria/2011/T-843-11.htm

Corte Interamericana de Derechos Humanos - CIDH. (1999). Caso de los "Niños de la Calle" (Villagrán Morales y otros) vs. Guatemala. Fondo. Sentencia del 19 de noviembre de 1999. Serie C N. ${ }^{\circ} 63$.

Corte Interamericana de Derechos Humanos - CIDH. (2002). Condición jurídica y derechos humanos del niño. Opinión Consultiva OC-17/02 del 28 de agosto de 2002. Serie A N. ${ }^{\circ} 17$. Recuperado de http://www.corteidh.or.cr/docs/opiniones/seriea_17_esp.pdf 
Corte Interamericana de Derechos Humanos - CIDH. (2004). Caso "Instituto de Reeducación del Menor" vs. Paraguay. Sentencia del 2 de septiembre de 2004. Excepciones Preliminares, Fondo, Reparaciones y Costas. Recuperado de http://www.corteidh.or.cr/docs/casos/articulos/seriec_112_esp.pdf

Corte Interamericana de Derechos Humanos - CIDH. (2006). Caso de las masacres de Ituango vs. Colombia. Sentencia del 1 de julio de 2006. Serie C N. 148 . Recuperado de http://www.corteidh.or.cr/docs/casos/articulos/seriec_148_esp.pdf

Corte Interamericana de Derechos Humanos - CIDH. (2009). Caso de la masacre de las Dos Erres vs. Guatemala. Sentencia del 24 de noviembre de 2009. Excepción Preliminar, Fondo, Reparaciones $\quad$ y Costas. Recuperado de http://www.corteidh.or.cr/docs/casos/articulos/seriec_211_esp.pdf

Corte Interamericana de Derechos Humanos - CIDH. (2009). Caso González y otras ("Campo Algodonero”). vs. México. Sentencia del 16 de noviembre de 2009. Excepción preliminar, fondo, reparaciones y costa. Recuperado de http://www.corteidh.or.cr/docs/casos/articulos/seriec_205_esp.pdf

Corte Interamericana de Derechos Humanos - CIDH. (2010). Caso Chitay Nech y otros vs. Guatemala. Sentencia del 25 de mayo de 2010. Excepciones Preliminares, Fondo, Reparaciones $\quad \mathrm{y}$ Costas. Recuperado de http://www.corteidh.or.cr/docs/casos/articulos/seriec_212_esp.pdf

Corte Interamericana de Derechos Humanos - CIDH. (2012). Caso Fornerón e hija vs. Argentina. Fondo, Reparaciones y Costas. Sentencia de 27 de abril de 2012. Serie C N. 242.

Corte Interamericana de Derechos Humanos. (19 de noviembre de 1999). www.corteidh.or. Obtenido de www.corteidh.or.cr/docs/casos/articulos/Seriec_63_esp.pdf 
Corte Interamericana de Derechos Humanos. (2018). www.corteidh.or.cr. Obtenido de www.corteidh.or.cr/sitios/libros/todos/docs/ABCCorteIDH.pdf

Corte interamericana de Derechos Humanos. (s.f.). www.corteidh.or.cr. Obtenido de www.corteidh.or.cr/docs/casos/articulos/seriec_148_esp.pdf

Corte Suprema de Justicia. (26 de septiembre de 2000). Expediente 13466. [MP Fernando Arboleda].

Corte Suprema de Justicia. (26 de enero de 2006). Proceso 23706. Sala de Casación. [MP Marina Pulido de Barón].

Corte Suprema de Justicia Colombia, Sentencia 23706. (26 de enero de 2006). legal.legis.com.co. Obtenido de http://legal.legis.com.co/document/Index?obra=jurcol\&document=jurcol_7599204218e8f0 34e0430a010151f034

Corte Suprema de Justicia, Sala de Casacion Penal, Sentencia 13466. (27 de septiembre de 2000). legal.legis.com.co. Obtenido de legal.legis.com.co/document/Index?obra=jurcol\&document=jurcol_75992041aea5f034e04 30a010151f034

Defensoría del Pueblo. (2011). Mecanismos de protección contra la violencia intrafamiliar. Bogotá: Imprenta Nacional. Recuperado de http://cdim.esap.edu.co/BancoMedios/Documentos\%20PDF/mecanismos\%20de\%20protecci\%C3 $\%$ B3n\%20contra\%201a\%20violencia\%20intrafamiliar.pdf

Defensoría del Pueblo. (2012). Decimonoveno Informe del Defensor del Pueblo al Congreso de la República de Colombia. Bogotá. Imprenta Nacional. Recuperado de http://www.defensoria.gov.co/public/pdf/02/19_informe_congreso_II.pdf 
Departamento Nacional de Planeación - DNP. (3 de diciembre de 2007). Documento Conpes Social 109. Política Pública Nacional de Primera Infancia. “Colombia por la Primera Infancia”. Consejo Nacional de Política Económica Social. Recuperado de https://www.mineducacion.gov.co/1759/articles-177832_archivo_pdf_Conpes_109.pdf

Departamento Nacional de Planeación - DNP. (2009). Plan Nacional para la Niñez y la Adolescencia 2009-2019. Recuperado de http://www.sipi.siteal.iipe.unesco.org/sites/default/files/sipi_intervencion/plan-nacionalde-ninez-y-adolescencia-2009-2019.pdf

Departamento Nacional de Planeación - DNP. (2010). Plan Nacional de Desarrollo, PND (20102014). Bogotá. Recuperado de https://www.dnp.gov.co/Plan-Nacional-de-Desarrollo/PND2010-2014/Paginas/Plan-Nacional-De-2010-2014.aspx

Departamento Nacional de Planeacion. (3 de diciembre de 2007). https:// www.dnp.gov.co. Obtenido de https://www.dnp.gov.co/programas/desarrollo-social/pol\%C3\%ADticassociales-transversales/Paginas/infancia-y-adolescencia.aspx.

Donzelot, J. (1990). La policía de las familias. Valencia: Editorial Pretextos.

Ferreira, G. (1989). La mujer maltratada. Buenos Aires: Editorial Sudamericana.

Fiscalía General de la Nación. (7 de noviembre de 2014). Resolución 1948 de 2014 por medio de la cual se crea el Centro de Atención Penal Integral a Víctimas (CAPIV) de la Fiscalía General de la Nación, y se delega una función especial. Bogotá, Colombia: Diario Oficial 49.335.

Fiscalia General de la Nacion. (julio de 2006). repository.oim.org.co. Obtenido de https://repository.oim.org.co/bitstream/handle/20.500.11788/826/COLOIM\%200131.pdf?sequence=1\&isAllowed=y 
Fiscalia General de La nacion Colombia. (2009). https://www.fiscalia.gov.co. Obtenido de https://www.fiscalia.gov.co/colombia/wp-content/uploads/2012/03/spoa.pdf

Franco, S. (1999). El quinto: No matar. Contextos explicativos de la violencia en Colombia. Bogotá: Tercer Mundo.

Franco, S. (2008). La violencia en Colombia: una tragedia para no repetir. XVIII Congreso Mundial de Epidemiología y VII Congreso Brasilero de Epidemiología. Porto Alegre, Brasil. $\begin{array}{lllll}\text { Septiembre } & 22 & \text { de } & 2008 . & \text { Recuperado de }\end{array}$ http://www.epi2008.com.br/apresentacoes/MESA_REDONDA_22_09_15H45_pdf/Saul\% 20Franco.pdf

García-Moreno, C. y Watts, C. (2011). Violence Against Women: An Urgent Public Health Priority. Bulletin World Health Organization, 89(2). Recuperado de https://www.who.int/bulletin/volumes/89/1/10-085217.pdf?ua=1

Gonzalez, G. (2016). Consecuencias juridicas y politico criminalesde la elevacion de la edad del consentimiento sexual. Obtenido de http://criminet.ugr.es/recpc/18/recpc18-15.pdf.

Graça, M. (2001). El impacto de la guerra en los niños. Reino Unido.

Guerricaechevarría, C. y Echebúrua, E. (2005). Violencia sexual en la infancia: víctimas y agresores. Un enfoque clínico. España: Ariel.

Hodgkin, R. y Newell, P. (2007). Implementation Handbook for the Convention on the Rights of the Child. 3. ${ }^{a}$ edición completamente revisada, UNICEF, Ginebra, Suiza.

Ibañez, j. (s.f.). www.corteidh.or.cr. Obtenido de www.corteidh.or.cr/tablas/r25555.pdf 
Instituto Colombiano de Bienestar Familiar - ICBF. (2006). Lineamientos técnico administrativos misionales para la inclusión y la atención de familias en los programas y servicios del ICFB. Recuperado de https://www.icbf.gov.co/sites/default/files/procesos/lineamientos_tecnicos_para_la_inclusi on_y_atencion_de_familias.pdf

Instituto Colombiano de Bienestar Familiar - ICBF. (2007). Lineamientos técnicos para la inclusión y atención de familias. Recuperado de http://www.icbf.gov.co/portal/pls/portal/DEV_PORTAL.wwsbr_imt_services.GenericVie $\underline{w} ? \mathrm{p} \_$docname $=50257 . P D F \& p \_t y p e=D O C \& p \_v i e w s e r v i c e=V A H W S T H \& p \_s e a r c h s t r i n g=$

Instituto Colombiano de Bienestar Familiar - ICBF. (7 de mayo de 2007). Resolución 910 de 2007 por la cual se aprueban los Lineamientos Técnicos para el "Marco general y orientaciones de políticas públicas y planes territoriales en materia de infancia y adolescencia”. Bogotá, Colombia: Diario Oficial 47.417 del 21 de julio de 2009.

Instituto Colombiano de Bienestar Familiar - ICBF. (2012). Observatorio del Bienestar de la Niñez. Número 2. Bogotá.

Instituto Nacional de Medicina Legal y Ciencias Forenses - INMLCF. (2010). Forensis, 2010. Datos para la vida. Colombia. Recuperado de http://www.medicinalegal.gov.co/cifrasestadisticas/forensis

Instituto Nacional de Medicina Legal y Ciencias Forenses - INMLCF. (2011). Forensis, 2011. Datos para la vida. Colombia. Recuperado de http://www.medicinalegal.gov.co/cifrasestadisticas/forensis

Instituto Nacional de Medicina Legal y Ciencias Forenses - INMLCF. (2012). Examen médico-legal por presunto delito sexual. Forensis, 2012. Datos para la vida. Colombia. Recuperado de http://www.medicinalegal.gov.co/cifras-estadisticas/forensis 
Instituto Nacional de Medicina Legal y Ciencias Forenses - INMLCF. (2013). Forensis, 2013. Datos para la vida. Colombia. Recuperado de http://www.medicinalegal.gov.co/cifrasestadisticas/forensis.

ICBF. (17 de septiembre de 2009). www.icbf.gov.co. Obtenido de https://www.icbf.gov.co/sites/default/files/manual_para_la_ejecucionytratados_sep172009. pdf.

ICBF. (2016). www.icbf.gov.co. Obtenido de https://www.icbf.gov.co/gestiontransparencia/transparencia/normatividad

ICBF. (s.f.). www.icbf.gov.co. Obtenido de https://www.icbf.gov.co/instituto

Instituto Colombiano de Bienestar Familiar. (junio de 2018). www.icbf.gov.co. Obtenido de https://www.icbf.gov.co/sites/default/files/linea_pp_escnna_20180620.pdf.

Instituto Colombiano de Bienestar familiar. (s.f.). www.icbf.gov.co. Obtenido de https://www.icbf.gov.co/bienestar/sistema-nacional-bienestar-familiar.

Instituto Geografico Agustin Codazzi. (2016). www.colombiamania.com. Obtenido de http://www.colombiamania.com/departamentos/boyaca.html.

Instituto Nacional de Medicina Legal y Ciencias Forenses. (junio de 2016). WWW.medicinalegal.gov.co. Obtenido de www.medicinalegal.gov.co/documents/20143/49526/Forensis+2016.+Datos+para+la+vida .pdf.

Intebi, I. (2007). Valoración de sospechas de abuso sexual infantil. Recuperado de http://www.serviciossocialescantabria.org/uploads/documentos\%20e\%20informes/sospech asabusoinfantil.pdf. 
Intebi, I. (febrero de 2007). www.serviciossocialescantabria.org. Obtenido de WwW.serviciossocialescantabria.org/uploads/documentos\%20e\%20informes/sospechasAbu soInfantil.pdf.

Intebi, I. (2011). Proteger,reparar, penalizar. Buenos Aires: Ediciones Granica.

Intebi, I. (2011). Proteger, reparar, penalizar: evaluación de las sospechas de abuso sexual infantil. Argentina: Granica.

Klevens, J., De La Cruz, L., Arango, P., Rodríguez, H., Peñaranda, C., Pulido, C., Rincón, M., Vargas, L., García, M., Arenas, L. y Estrada, D. (1989). Prevención primaria en salud mental. Revista Latinoamericana de Psicología, 21(2), pp. 243-253. Fundación Universitaria Konrad Lorenz. Bogotá.

Ley 1098 de 2006 Congreso de la republica de Colombia. (8 de noviembre de 2006). www.oas.org. Obtenido de https://www.oas.org/dil/esp/Codigo_de_la_Infancia_y_la_Adolescencia_Colombia.pdf

Ley 115 de 1994 Congreso de la Republica de Colombia. (8 de febrero de 1994). WWW.mineducacion.gov.co. Obtenido de https://www.mineducacion.gov.co/1621/articles85906_archivo_pdf.pdf

López, F. (1999). La inocencia rota. Abusos sexuales a menores: cómo prevenir, detectar y superar una agresión sexual. Barcelona: Océano Grupo Editorial.

Ministerio de Educación nacional - MEN. (s. f.). Documento de orientaciones de política para la promoción de derechos y la prevención, detección y atención de las violencias en la escuela. Recuperado de https://www.mineducacion.gov.co/1759/articles328700_archivo_pdf_violencia_sexual.pdf

Ministerio de Proteccion Social ¡, Colombia. (s.f.). bdigital.unal.edu.co. Obtenido de bdigital.unal.edu.co/45579/1/laviolenciasexualencolombia.pdf 
Ministerio de Proteccion Social. (febrero de 2003). Minsalud.gov.co. Obtenido de https://www.minsalud.gov.co/Documentos\%20y\%20Publicaciones/POLÍTICA\%20NACI ONAL\%20DE\%20SALUD\%20SEXUAL\%20Y\%20REPRODUCTIVA.pdf

Ministerio de Salud Republica de Colombia. (enero de 2011). https://minsalud.gov.co. Obtenido de https://www.minsalud.gov.co/sites/rid/Lists/BibliotecaDigital/RIDE/VS/PP/Modelogestion-DSR.pdf

Ministerio de salud republica de Colombia. (s.f.). https://www.minsalud.gov.co. Obtenido de https://www.minsalud.gov.co/Documentos\%20y\%20Publicaciones/MODELO\%20DE\%20 ATENCIÓN\%20A\%20VÍCTIMAS\%20DE\%20VIOLENCIA\%20SEXUAL.pdf

Ministerio de salud y proteccion social. (s.f.). https://oimg.org.go. Obtenido de oim.org.co/sites/default/files/Guía_metodologica_abordaje_intersectorial_violencia_sexual .pdf

Naciones unidas Oficina alto comisionado. (s.f.). www.ohchr.org. Obtenido de https://www.ohchr.org/sp/professionalinterest/pages/opsccrc.aspx

Naciones Unidas, oficina contra la droga y el delito. (15 de noviembre de 2000). www.unodc.org. Obtenido de https://www.unodc.org/documents/treaties/UNTOC/Publications/TOC\%20Convention/TO Cebook-s.pdf

Naciones Unidas, Oficina del alto comisionado. (s.f.). www.ohchr.org. Obtenido de https://www.ohchr.org/sp/professionalinterest/pages/cedaw.aspx.

OAS.org. (s.f.). $\quad$ www.oas,org. Obtenido de https://www.oas.org/dil/esp/Convencion_Internacional_de_los_Derechos_del_Nino_Colo mbia.pdf 
OEA.

(2001).

www.oas.org.

Obtenido

de

https://www.oas.org/es/centro_noticias/comunicado_prensa.asp?sCodigo=D-014/16

OEA.

(2016).

www.oas.org.

Obtenido

de

https://www.oas.org/es/centro_noticias/comunicado_prensa.asp?sCodigo=D-014/16

OEA.

(s.f.).

www.oas.org.

Obtenido

de

http://www.oas.org/es/cidh/mandato/Basicos/declaracion.asp

ONU. (1992). www.oas.org. Obtenido de https://www.oas.org/juridico/spanish/tratados/a-60.html

ONU.

(2000).

www, ohch.org.

Obtenido

de

https://www.ohchr.org/Documents/ProfessionalInterest/ProtocolTraffickingInPersons_sp.p df

ONU. (s.f.). www.onu. Obtenido de www.onu.cl/es/sample-page/agencias-fondos-yprogramas/unicef/

Organización de las Naciones Unidas - ONU. (1979). Convención para la Eliminación de todas las Formas de Discriminación contra la Mujer (CDAW). Recuperado de https://www.ohchr.org/sp/professionalinterest/pages/cedaw.aspx

Organización de las Naciones Unidas - ONU. (1989). Convención sobre los Derechos del Niño. Recuperado de https://www.ohchr.org/sp/professionalinterest/pages/crc.aspx

Organización de las Naciones Unidas - ONU. (1992). Declaración sobre la protección de todas las personas contra las desapariciones forzadas. Aprobada por la Asamblea General en su resolución 47/133 de 18 de diciembre 1992. Recuperado de https://www.acnur.org/fileadmin/Documentos/BDL/2002/1428.pdf

Organización de las Naciones Unidas - ONU. (2000). Protocolo para prevenir, reprimir y sancionar la trata de personas, especialmente mujeres y niños, que complementa la Convención de las 
Naciones Unidas contra la Delincuencia Organizada Transnacional. Recuperado de https://www.ohchr.org/documents/professionalinterest/protocoltraffickinginpersons_sp.pdf

Organización de los Estados Americanos - OEA. (1948). Declaración Americana de los Derechos $y$ Deberes del Hombre. IX Conferencia Internacional Americana. Recuperado de http://www.oas.org/es/cidh/mandato/Basicos/declaracion.asp

Organización de los Estados Americanos - OEA. (1988). Protocolo Adicional a la Convención Americana sobre Derechos Humanos en Materia de Derechos Económicos, Sociales y Culturales "Protocolo de San Salvador". Suscrito en San Salvador el 17 de noviembre de 1988. Aprobado por Colombia mediante la Ley 319 del 20 de septiembre de 1996.

Organización de los Estados Americanos - OEA. (1994a). Convención Interamericana sobre Desaparición Forzada de Personas. Adoptada en Belém do Para, Brasil, el 9 de junio de 1994, en el vigésimo cuarto período ordinario de sesiones de la Asamblea General de la OEA.

Organización de los Estados Americanos - OEA. (1994b). Convención Interamericana para Prevenir, Sancionar y Erradicar la Violencia contra la Mujer "Convención de Belem Do Pará". Recuperado de http://www.oas.org/juridico/spanish/tratados/a-61.html

Organización de los Estados Americanos - OEA. (2001). Carta Democrática Interamericana. Aprobada el 11 de septiembre de 2001, en sesión especial de la Asamblea de la OEA en Lima (Perú). Recuperado de http://www.oas.org/charter/docs_es/resolucion1_es.htm

Organización de los Estados Americanos - OEA. (2013). Derecho del niño y la niña a la familia. Cuidado alternativo. Poniendo fin a la institucionalización en las Américas. Recuperado de https://www.oas.org/es/cidh/infancia/docs/pdf/informe-derecho-nino-a-familia.pdf 
Organización Internacional del Trabajo - OIT. (1999). Convenio sobre la prohibición de las peores formas de trabajo infantil y la acción inmediata para su eliminación. Recuperado de https://www.icbf.gov.co/cargues/avance/docs/cv_oit_0182_99.htm

Organización Mundial de la Salud - OMS. (2002). Informe mundial sobre la violencia y la salud. Resumen. Recuperado de https://www.who.int/violence_injury_prevention/violence/world_report/es/summary_es.pd $\underline{\mathrm{f}}$

Palomino, S. (25 de abril de 2017). www.reforma.com. Obtenido de https://www.reforma.com/aplicacioneslibre/articulo/default.aspx?id=1098661\&md5=093f 1334a2b84e7ec0622e31ef1b47d5\&ta=0dfdbac11765226904c16cb9ad1b2efe

Perez, J. y. (2008). https://definicion.de/onu/. Obtenido de https://definicion.de/onu/

PNUD. (28 de julio de 2014). www.co.undp.org. Obtenido de www.co.undp.org/content/colombia/es/home.html

Presidencia de la República de Colombia. (27 de noviembre de 1989). Decreto 2737 por el cual se expide el Código del Menor. Derogado por el art. 217, Ley 1098 de 2006 a excepción de los artículos 320 a 325 y los relativos al juicio especial de alimentos. Recuperado de http://www.oas.org/dil/esp/decreto_2737_de_1989_colombia.pdf

Presidencia de la República de Colombia. (23 de enero de 2017). Decreto 87 de 2017 por el cual se reglamenta el funcionamiento del Fondo contra la Explotación Sexual de Niños, Niñas y Adolescentes, adscrito al Instituto Colombiano de Bienestar Familiar. Recuperado de http://es.presidencia.gov.co/normativa/normativa/DECRETO\%2087\%20DEL\%2023\%20E NERO\%20DE\%202017.pdf

Presidencia de la Republica de Colombia, Decreto 87. (23 de enero de 2017). Obtenido de https://www.funcionpublica.gov.co/eva/gestornormativo/norma.php?i=79073 
Presidencia de la Republica de Colombia, Decreto 87 de 2017. (23 de enero de 2017). www.funcionpublica.gov.co. Obtenido https://www.funcionpublica.gov.co/eva/gestornormativo/norma.php?i=79073

Presidencia de la Republica de Colombia, Decreto 936. (10 de mayo de 2013). www.icbf.gov.co.

Sabino, Carlos. (1986). Cómo hacer una tesis: guía para la elaboración y redacción de trabajos científicos. Buenos Aires: Humanista.

Save de Children. (2001). Abuso sexual infantil: Manual de formación para profesionales. Recuperado de https://www.savethechildren.es/sites/default/files/imce/docs/manual_abuso_sexual.pdf

Save the Children. (s. f.). Violencia contra la infancia. Recuperado de https://www.savethechildren.es/trabajo-ong/proteccion-infantil/violencia-contra-lainfancia/abuso-\%20violencia-sexual

Secretaria Disttrital de Integracion Social. (noviembre de 2014). https://www.integracionsocial.gov.co. Obtenido de www.integracionsocial.gov.co/index.php/noticias/116-otros/525-en-bogota-humana-lasvictimas-ya-cuentan-con-un-capiv

Senado de la republica de Colombia. (24 de septiembre de 1996). www.secretariasenado.gov.co. Obtenido de www.secretariasenado.gov.co/senado/basedoc/ley_0319_1996.html.

Sistema Nacional de Derechos Humanos y DIH. (2014). www.drechos humanos.gov.co. Obtenido de www.derechoshumanos.gov.co/Observatorio/Publicaciones/Documents/2014/140815estrategia_web.pdf. 
Soria, M. y Hernández, J. (1994). El agresor sexual y la víctima. Barcelona: Marcombo.

Unicef. (2013). Derechos del niño. Recuperado de https://www.unicef.org.co/derechos-del-ninio

Universidad Javeriana. (2008). Congreso Iberoamericano sobre Maltrato Infantil. Recuperado de http://blog.colombiahoy.org/2007/05/22/primer-congreso-iberoamericano-sobremaltrato-infantil.aspx

UNICEF. (junio de 2006). www.un.org. Obtenido de https://www.un.org/es/events/childrenday/pdf/derechos.pdf

$\begin{array}{llll}\text { UNICEF. } & \text { (s.f.). } & \text { Obtenido de }\end{array}$ https://www.unicef.org/honduras/GuatemalaAbuso_sexualSP.pdf

Vargas, C., Vargas, E. y Mejía de C., S. (1997). Intervención en casos de abuso sexual en estados de crisis. $3^{\text {a }}$. Edición. Santa Fe de Bogotá: Seguro Social y la Asociación Afecto. 